\section{To: (Receiving Organization)}

T. Choho, CVDE Project Manager

5. Proj./Prog./Dept./Div.:

Spent Nuclear Fuel Project CVDF

8. Originator Remarks:

For approval and release

11. Receiver Remarks:

11A. Design Baseline Document? $O$ Yes $O$ No
3. From: (Originating Organization)

Numatec Hanford Company

6. Design Authority/Design Agent/Cog. Engr.:

EC Ocoma
4. Related EDT No::

$\mathrm{N} / \mathrm{A}$

7. Purchase Order No.

$\mathrm{N} / \mathrm{A}$

9. Equip./Component No.:

$\mathrm{N} / \mathrm{A}$

10. System/Bldg./Facility;

CVD Facility $w-441$

12. Major Assm. Dwg. No.:

N/A

13. Permit/Permit Application No.

$\mathrm{N} / \mathrm{A}$

14. Required Response Date:

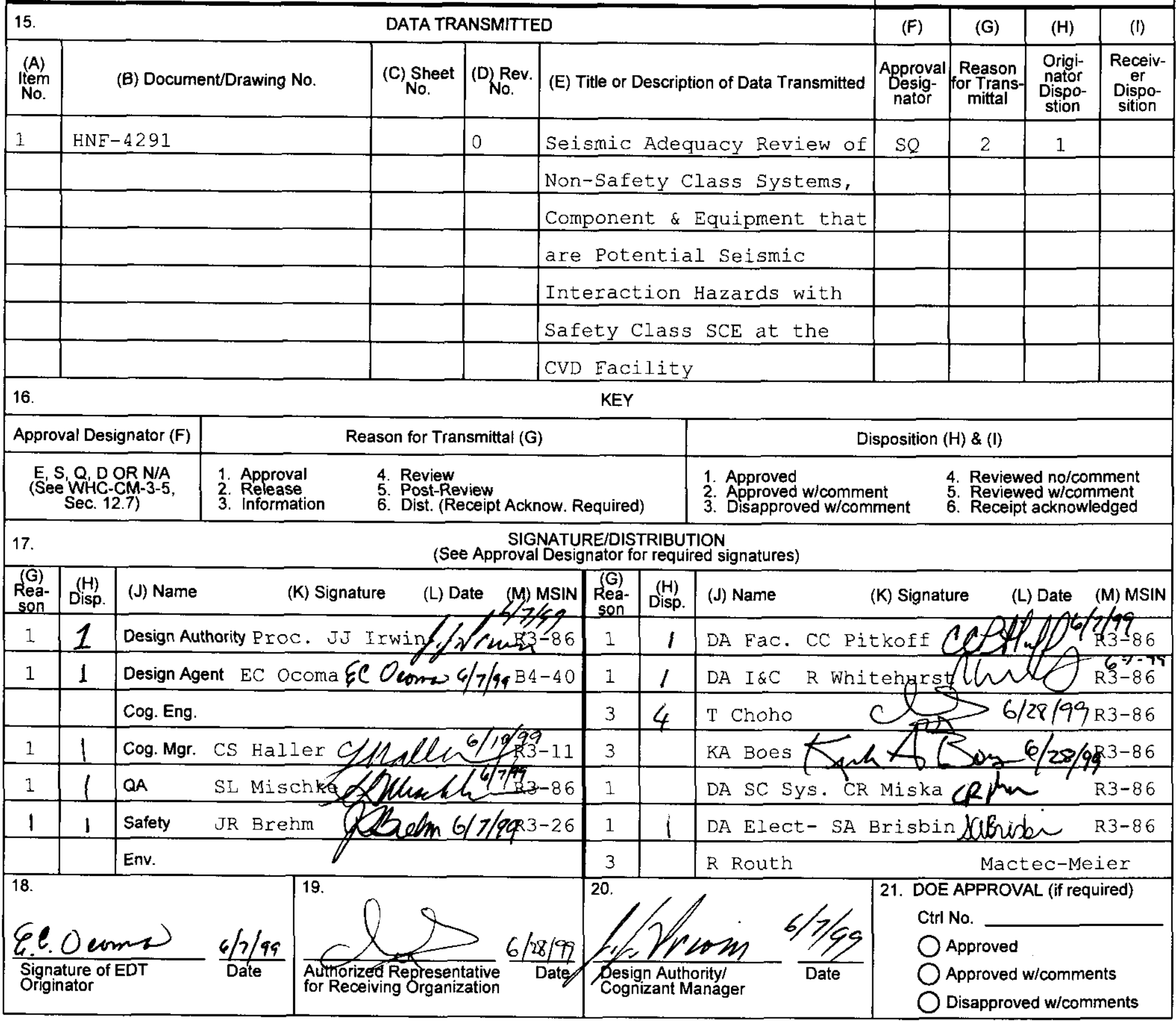




\title{
SEISMIC ADEQUACY REVIEW OF PC012 SCES THAT ARE POTENTIAL SEISMIC HAZARDS WITH PC3 SCES - CVD FACILITY
}

E. C. OCOMA (EDNW)

For Numatec Hanford Company

Richland, WA 99352

U.S. Department of Energy Contract DE-AC06-96RL13200

\author{
EDT/ECN: 615963 \\ Org Code: SF840000 \\ UC: 721 \\ B\&R Code: $39 E N 70400$ \\ Charge Code: $2 \mathrm{~K} 02$ \\ Total Pages: 57
}

Key Words: $3 / 1$ Seismic Evaluation, Systems, Components, Equipment, CVDE

Abstract: This document provides seismic adequacy review of PC012 Systems, Components \& Equipment anchorage that are potential seismic interaction hazards with PC3 SCEs during a Design Basis Earthquake. The PC012 items are identified in the Safety Equipment List as 3/1 SCEs.

TRADEMARK DISCLAIMER. Reference herein to any specific commercial product, process, or service by trade name, trademark, manufacturer, or otherwise, does not necessarily constitute or imply its endorsement, recommendation, or favoring by the United States Government or any agency thereof or its contractors or subcontractors.

Printed in the United States of America. To obtain copies of this document, contact: Document Control Services, P.O. Box 950, Mailstop H6-08, Richland WA 99352, Phone (509) 372-2420; Fax (509) 376-4989.

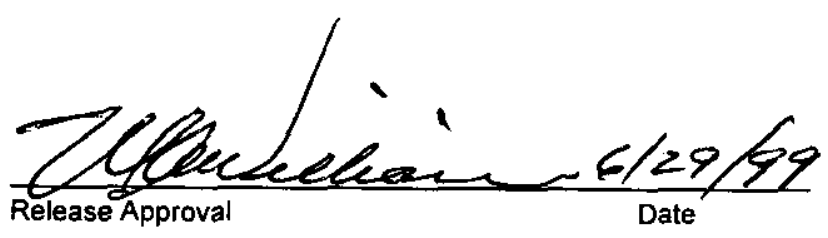

Approved For Public Release

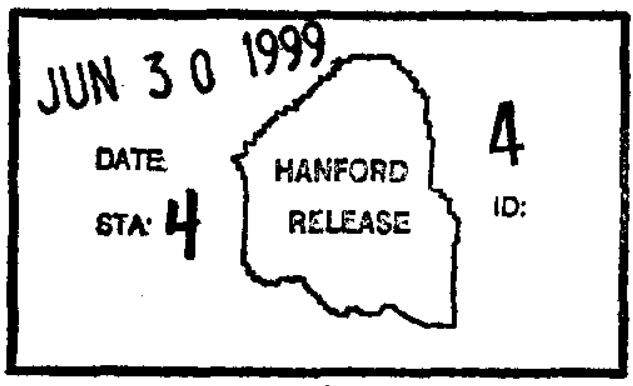

Release Stamp 


\section{RECORD OF REVISION}

(2) Title

Seismic Adequacy Review for PC012 SCE Anchorage During A DBE at CVDF

Change Control Record

(3) Revision

(4) Description of Change - Replace, Add, and Delete Pages

\begin{tabular}{|l|l}
\hline RS 0 & $\begin{array}{l}\text { (7) } \\
\text { Initial Release of Document (May.1999) EDT } 615963\end{array}$ \\
\hline
\end{tabular}

Authorized for Release

(5) Cog. Engr. $\quad$ (6) Cog. Mgr. Date

Eccoome didelen EC Ocoma 


\title{
SEISMIC ADEQUACY REVIEW \\ OF NON-SAFETY CLASS \\ SYSTEMS, COMPONENTS AND EQUIPMENT (SCE) \\ THAT ARE POTENTIAL SEISMIC INTERACTION HAZARDS WITH SAFETY CLASS SCE \\ AT THE CVD FACILITY
}

\author{
HNF-4291, Revision 0
}

May 1999

Prepared By: $\frac{G, C \text {. Oeonas }}{\text { E. C. Ocoma }} \quad$ Date: $6 / 60 / 99$

Approved By: 
1.0 Introduction

$\begin{array}{llr}2.0 & \text { Purpose } & 1\end{array}$

$\begin{array}{ll}3.0 & \text { Evaluation Criteria }\end{array}$

$\begin{array}{lll}4.0 & \text { Evaluation Methodology } & 2\end{array}$

$\begin{array}{lll}5.0 & \text { Findings } & 4\end{array}$

6.0 Conclusion $\quad 4$

7.0 Personnel Qualifications and Training 11

$\begin{array}{lll}8.0 & \text { References } & 13\end{array}$

$\begin{array}{lll}9.0 & \text { Calculations } & 14\end{array}$

\section{LIST OF TABLES}

Table A-1A. Cold Vacuum Drying Facility - PC3 Equipment/Structure Listing 26

Table A-2A. Cold Vacuum Drying Facility - PC3 Piping System Listing 27

Table A-4A. Cold Vacuum Drying Facility - PC3 I\&C Listing 29

Table A-1B. Cold Vacuum Drying Facility - 3/1 Equipment/Structure Listing 32

Table A-2B. Cold Vacuum Drying Facility - 3/1 Piping System Listing 37

Table A-4B. Cold Vacuum Drying Facility - 3/1 I\&C Listing 41

\section{APPENDICES}

Appendix A. Autopipe program input and output files 


\subsection{INTRODUCTION}

The Cold Vacuum Drying Facility (CVDF) is a new facility that is being constructed in the 100 Area. The CVDF systems, components, and equipment (SCEs) that are classified as Safety Class (SC) with a Performance Category 3 (PC3) seismic design requirement are all located in the process bays. There are also SCEs in the process bays, that are classified as Safety Significant (SS) and General Service (GS) with PC1 and 2 seismic design requirement respectively. Additionally, the SS and GS SCEs (hazard source) that could potentially interact with SC SCEs (hazard target) are further required to be designed for potential interaction seismic design requirements. The seismic requirements for the potential interaction (usually expressed as 3/1) SCEs are described in Reference 2. In this evaluation, the PC1 and 2 will be combined into PC12. The Performance Category designations for the SC SCEs are identified in HNF-SD-SNF-SEL-002, Rev. 6A, "Safety Equipment List for the Spent Nuclear Fuel Project CVDF" (SEL, Ref. 1). The 3/1 items are identified in the Master Equipment List for the Spent Nuclear Fuel Project CVDF" (MEL, Ref. 7).

\subsection{PURPOSE}

The purpose of this evaluation is to verify the seismic anchorage adequacy of the $3 / 1$ SCEs during a PC3 Design Basis Earthquake (DBE). Potential interaction between PC3 SCEs will be evaluated also. In this evaluation, the PC3 to PC3 interaction will be expressed as $3 / 3$. The structural integrity of a PC3 item or the performance of its safety function shall not be compromised by the structural failure of a PC12 or an adjacent PC3 during a DBE event. The $3 / 1$ evaluation for PC12 SCE's potential seismic deficiencies or interaction modes associated with structural failure and falling, sliding, and toppling will be performed. Potential proximity interaction will also be evaluated for both PC3 and PC12 SCEs. The $3 / 3$ evaluation for the PC3s will be performed by verifying the type of anchor bolt used (if bolted) per GC-ANCR-01, the seismic displacements, and the applied seismic demand in the structural or stress analysis documentation that are filed in the Project Library. The PC12 piping systems in the process bays will also be evaluated by verifying the structural analysis performed for seismic $3 / 1$ loading based on the applicable piping code (ASME B31.3 or B31.9) requirements for code stress compliance. This is to assure that the valves or other components being supported by the pipe do not become potential missiles if the pipe-to-valve connections fail structurally during a DBE. The evaluation for the building structural components that are identified as seismic $3 / 1$ in Reference 1 , Table $A-1$, is not within the scope of this task. It is assumed that the building structural components that are used for supporting the PC3 and PC12 SCEs will remain intact during the $D B E$.

\subsection{EVALUATION ACCEPTANCE CRITERIA}

For the CVD Facility, the evaluation acceptance criteria for the seismic adequacy of the 3/1 SCEs are as follows:

1. The anchorage of equipment is acceptable if designed and analyzed for $3 / 1$ seismic demand and applied in accordance to the guidelines of Reference 2. The design analysis shall be documented indicating the seismic magnitude considered.

2. The supports and anchorages for distribution systems and components are acceptable if designed and analyzed for $3 / 1$ seismic demand and applied in accordance to the 
guidelines of Reference 2. The design analysis shall be documented indicating the seismic magnitude considered.

3. The $3 / 1$ piping systems are acceptable if designed and analyzed to comply with ASME piping code. The analysis shall be documented to show that the interface between the components and the piping remain intact after the DBE. The analysis shall also show that valve actuators do not fail structurally and become missiles during a DBE. The seismic displacements at mid-span between supports or hangers shall be documented also.

4. Proximity interaction is acceptable if the $3 / 1$ SCEs weigh approximately equal to or less than the PC3 SCE.

5. Anchorage acceptability of $3 / 1$ electrical distribution panels, light fixtures, and junction boxes that are already installed may be evaluated by field walkdown per Reference 2 guidelines if documented analyses do not exist.

6. Acceptability of unanchored $3 / 1$ temporary equipment and specialty tools shall be evaluated by using the zone of influence plotted in Figure 4.1 and acceptance criteria \#4.

7. Acceptability of proximity interaction between PC3 SCEs shall be evaluated by verifying the structural analysis for seismic displacement interferences and that the proper seismic demand was applied. Capacities of standard designed support hardware shall be verified against the seismic demand for acceptability.

8. Use of anchor bolt type and brand other than those listed in GC-ANCR-01 for PC3 SCEs is not acceptable.

9. For the SCIC GFE Panels, it is acceptable for the sheet metal enclosure to be dented and deformed but not perforated by $3 / 1$ SCEs. The Panels shall remain standing after a PC3 DBE. Interaction with similar or larger size equipment or component is not acceptable.

10. It is acceptable for the SCHe piping to be bent, twisted and dented but not to the extent that there is no flow through the pipe. Interaction between the $\mathrm{SCHe}$ and the support that may produce minor cracks or loosening of threaded connections that are potential leak path are not acceptable. The connection between the piping and the flexible hoses shall remain intact.

\subsection{EVALUATION METHODOLOGY}

The physical arrangements of PC3 SCEs are almost identical for each process bay, therefore the evaluation of one bay applies to the rest of the bays. The process bays are bounded by column lines $A$ through $E$ and 3 through 7 . The column lines are shown on numerous drawings (e.g. $\mathrm{H}-1-82237)$.

The first step is to develop a list identifying the PC3 SCEs. The PC3 SCEs along with 3/1 SCEs are listed in the Tables of Reference 1. Using the Tables of Reference 1, the PC3 SCEs were separated and tabulated in Tables A-1A, A-2A, and A-4A for Equipment and 
Structures, Piping, and Instrumentation and Controls respectively. The valve listing will not be used because the valves are included in the piping systems.

The next step is to develop a list identifying all potential $3 / 1$ SCEs. Using the Tables in Reference 1, the 3/1 SCEs were separated and tabulated in Tables A-1B, A-2B, and A-4B for Equipment and Structures, Piping, and Instrumentation and Controls respectively. The unshaded cells are new inputs to the Tables. The seismic design requirements are displayed under "Seismic" column.

A search for structural analysis documents was performed to verify the seismic loading criteria used. If structural analysis has been performed for the subject SCEs, the analysis was reviewed for proper application of the seismic loading guidelines provided in Reference 2.

Since the facility is new, the evaluation will be conducted as follows:

1. Verification for anchorage adequacy by design and analysis for the $3 / 1$ SCEs that are identified in Tables A-1B, A-2B, and A-4B.

2. Use the seismic evaluation guidelines presented in WHC-SD-GN-DGS-30006, (Reference 2) for new SCEs. The zone of influence is presented in Figure 4.1.

3. If already installed, evaluate by field walkdown the distribution systems that are to be field routed and do not have support spacing and configuration on the drawing.

4. Review the $3 / 1$ piping systems' stress analysis to verify that the $3 / 1$ seismic demand was considered in the analysis. Review that the worst load case was applied to the supports for proper design.

5. Review the PC3 piping systems' analysis to obtain displacements for the proximity evaluation.

6. Final field walkdown for proximity evaluation for interaction sources and targets that have been relocated or installed after this evaluation. There are equipment or systems that do not have drawings or data at all. 


\subsection{FINDINGS}

1. There are various $3 / 1$ SCEs in Reference 1 that are not located in the process bays and should not be designated as such since all PC3 SCEs are in the process bays.

2. The design for the Fire Protection System piping was performed in accordance with the requirements of NFPA 13 whose seismic design loading is less than Reference 2 requirement for potential $3 / 1$ seismic design.

3. Documentation for the dynamic analysis for the SCHe piping systems and the SC supports routed under the mezzanine need to be provided. There is potential for the $\mathrm{SCHe}$ piping systems and supports to interact with the adjacent SC systems and supports. The $\mathrm{SCHe}$ piping is semi-encased in $\mathrm{P} 1000$ Unistrut channel. The piping is not laterally restrained during a DBE. There is also potential for shaking that may loosen or damage the fittings and become leak path.

4. The numerous piping that are routed to the PES skid are supported by trapezes with long hanger rods from the mezzanine. There is a trapeze inside a trapeze and also beside a trapeze. The pipes and the trapezes are in close proximity to the vertical run of the SCHe piping (not yet installed).

5. The enclosures for the SCHe Panel A and $\mathrm{B}$ are new PC3 items and are not listed in Reference 1. The structural analysis for the $\mathrm{SCHe}$ Panel $\mathrm{A}$ and $\mathrm{B}$ missile barrier need to be provided. The analysis should show; the allowable impact force (lbf) of the $3 / 1$ SCE on the enclosure to prevent interaction between the enclosure and the SCHe Panel; and the allowable weight (lbs) of the $3 / 1$ SCE to prevent perforation of the enclosure's expanded metal.

6. The stress analysis for the $3 / 1$ piping systems to verify that the $3 / 1$ seismic demand was considered in the analysis need to be provided. This is to ascertain that the worst load case was applied to the supports for proper design. Also, this will assure that the valves or other components being supported by the pipe do not become potential missiles if the pipe-to-valve connections fail structurally during a DBE.

7. The stair to the mezzanine, which is a building component, is restrained at the floor by two bolts and may potentially interact with the SCIC Panels $(\mathrm{H}-2-82180)$ located at the foot of the stair and the SCIC Seismic Sensor under the stair.

8. There are PC3 SCEs that are anchored or designed to be anchored with anchor bolts that are not approved for Hanford Site use.

\subsection{CONCLUSIONS}

The acceptability of the anchorage adequacy and the basis for the disposition is explained in the "Comments" column in Tables A-1B, A-2B, and A-4B. During the evaluation, there are still a few PC3 and 3/1 SCEs not shown on the drawings to indicate locations and sizes. These SCEs will be evaluated accordingly when the required data becomes available. The deficient items are listed in pages 5 through 10. 


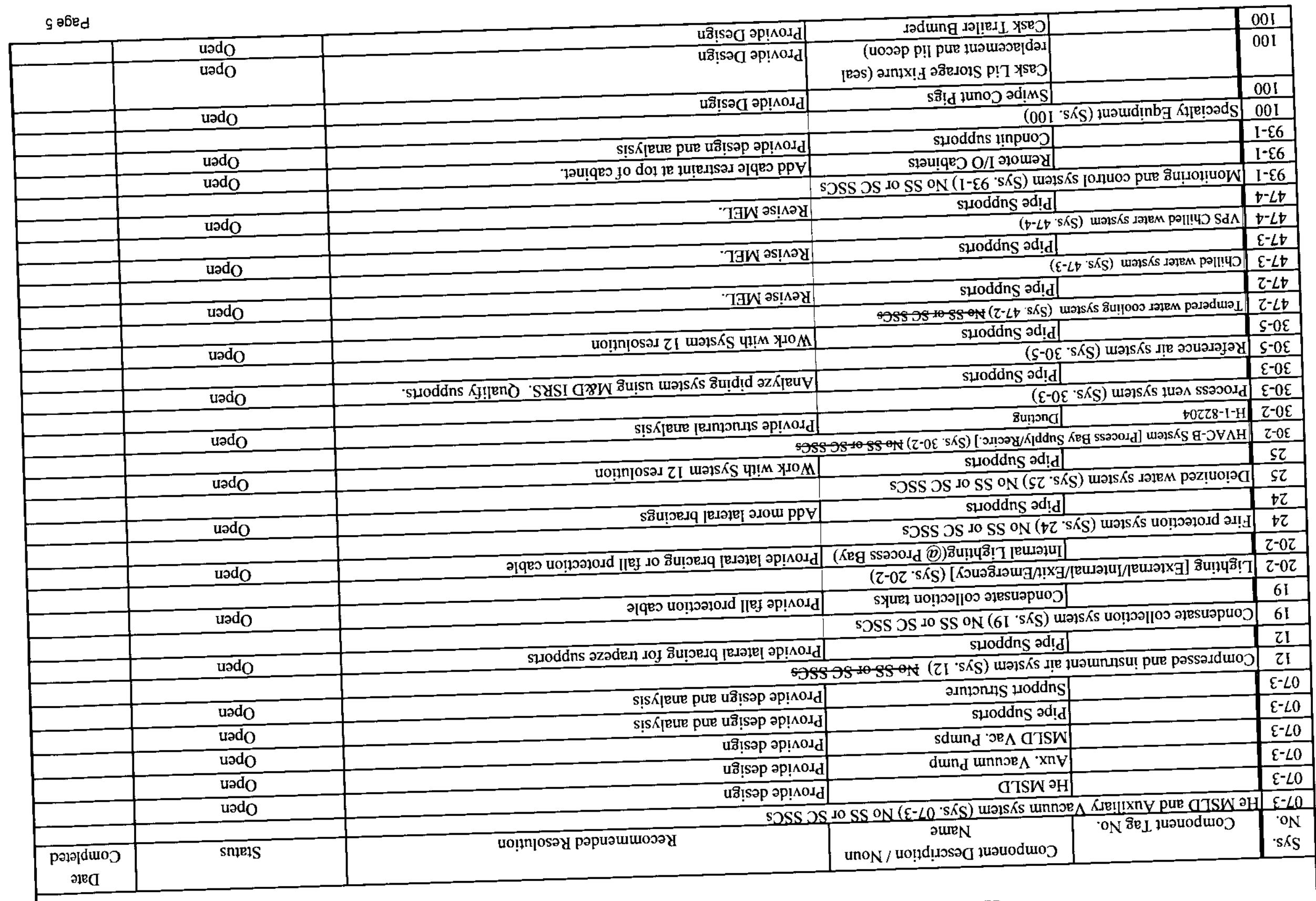

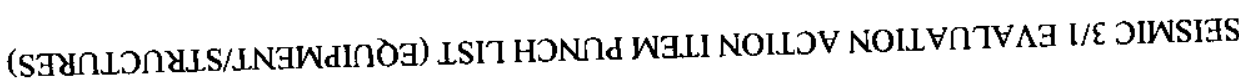




\begin{tabular}{|c|c|c|c|c|c|}
\hline \multicolumn{6}{|c|}{ SEISMIC 3/1 EVALUATION ACTION ITEM PUNCH LIST (EQUIPMENT/STRUCTURES) } \\
\hline $\begin{array}{l}\text { Sys. } \\
\text { No. }\end{array}$ & Component Tag No. & $\begin{array}{c}\text { Component Description / Noun } \\
\text { Name } \\
\end{array}$ & Recommended Resolution & Status & $\begin{array}{c}\text { Date } \\
\text { Completed }\end{array}$ \\
\hline $\mathrm{N} / \mathrm{A}$ & & $\begin{array}{l}\text { SCHe Panel A \& B Enclosure for } \\
\text { Missile Barrier }\end{array}$ & $\begin{array}{l}\text { Perform dynamic analysis in accordance with HNF-PRO-097 to show } \\
\text { structural adequacy and displacements to prevent interaction with } \\
\text { SCHe components. Provide allowable impact force (lbf) to be } \\
\text { imparted by a 3/1 SCE to the enclosure to prevent toppling. Provide } \\
\text { allowable weights (lbs) for the } 3 / 1 \text { SCE to prevent perforation of the } \\
\text { expanded metal. }\end{array}$ & Open & \\
\hline N/A & $\mathrm{N} / \mathrm{A}$ & $\mathrm{PC} 3$ stair and mezzanine & $\begin{array}{l}\text { Perform displacement calculations for the stair to verify deflection at } \\
\text { SCIC cabinet height for interaction evaluation. Provide justification } \\
\text { for using Hilti HVA anchors that are not approved for Hanford Site } \\
\text { use on PC3 components. }\end{array}$ & Open & \\
\hline N/A & $\mathrm{N} / \mathrm{A}$ & Mezzanine Handrail & $\begin{array}{l}\text { Perform structural analysis for the handrails using the mezzanine } \\
\text { ISRS to prevent interaction with MCO auxillary systems when the } \\
\text { cask is in the process bay. }\end{array}$ & Open & \\
\hline N/A & & SCHe Panel A \& B & $\begin{array}{l}\text { Revise the anchor bolt design to use Hanford Site approved type and } \\
\text { brand for PC3 installation instead of the Hilti HVA. }\end{array}$ & On-going & \\
\hline & 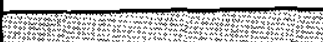 & | & & & \\
\hline
\end{tabular}




\section{SEISMIC 3/1 EVALUATION ACTION ITEM PUNCH LIST (EQUIPMENT/STRUCTURES)}

\begin{tabular}{|c|c|c|c|c|c|}
\hline $\begin{array}{l}\text { Sys. } \\
\text { No. }\end{array}$ & Component Tag No. & $\begin{array}{l}\text { Component Description / Noun } \\
\text { Name }\end{array}$ & Recommended Resolution & Status & $\begin{array}{c}\text { Date } \\
\text { Completed }\end{array}$ \\
\hline 100 & & Cask Trailer Wheel Chocks & Provide Design & Open & \\
\hline 100 & & $\begin{array}{l}\text { Cask Transporter Air Supply Glad } \\
\text { Hand }\end{array}$ & Provide Design & Open & \\
\hline 100 & & Process Hood Lift Fixture & Provide Design & Open & \\
\hline 100 & & $\begin{array}{l}\text { Storage Rack/Enclosure for } \mathrm{He} \\
\text { Leak Test Tools }\end{array}$ & Provide Design & Open & \\
\hline 100 & & $\begin{array}{l}\text { Storage Rack/Enclosure for MCO- } \\
\text { Cask Tools }\end{array}$ & Provide Design & Open & \\
\hline 101 & Special Tools (Sys. 101) & o SS or SC SSCs & & & \\
\hline 101 & & MCO Temporary Vent Connector & Provide Design & Open & \\
\hline 101 & & $\begin{array}{l}\text { Cask Lid Bolting Torque } \\
\text { Calibration Tool/Standard }\end{array}$ & Provide Design & Open & \\
\hline 101 & & $\begin{array}{l}\text { Cask Lid Bolting Torque Wrench } \\
\text { (Pneumatic) and Sockets }\end{array}$ & Provide Design & Open & \\
\hline 101 & & $\begin{array}{l}\text { Cask Lid Vent Port Cover } \\
\text { Removal and Installation Tools }\end{array}$ & Provide Design & Open & \\
\hline 101 & & Cask Lower Port Cover Tool & Provide Design & Open & \\
\hline 101 & & $\begin{array}{l}\text { Cask Lower Port SC Spoolpiece } \\
\text { Installation Tool }\end{array}$ & Provide Design & Open & \\
\hline 101 & & $\begin{array}{l}\text { MCO/VPS Process Port Connector } \\
\text { Bolt Torque Wrench }\end{array}$ & Provide Design & Open & \\
\hline 101 & & $\begin{array}{l}\text { MCO/NPS Process Port Connector } \\
\text { Handling Tool (T-Handle, } 2 \text { sizes) }\end{array}$ & Provide Design & Open & \\
\hline 101 & & $\begin{array}{l}\text { MCONPS Process Port Connector } \\
\text { He Leak Test Tools }\end{array}$ & Provide Design & Open & \\
\hline 101 & & $\begin{array}{l}\text { MCO/VPS Process Port Cover } \\
\text { Removal and Installation Tools }\end{array}$ & Provide Design & Open & \\
\hline N/A & & Safety Equipment List (Ref 1) & Update SEL to resolve Finding No. 1 & Open & \\
\hline N/A & N/A & $\begin{array}{l}\text { SCHe piping system under the } \\
\text { mezzanine }\end{array}$ & $\begin{array}{l}\text { Perform dynamic analysis using mezzanine ISRS for piping and } \\
\text { Unistrut channel supports for Finding No. } 3\end{array}$ & Open & \\
\hline
\end{tabular}




\begin{tabular}{|c|c|c|c|c|c|}
\hline \multicolumn{6}{|c|}{ SEISMIC 3/1 EVALUATION ACTION ITEM PUNCH LIST (EQUIPMENT/STRUCTURES) } \\
\hline $\begin{array}{l}\text { Sys. } \\
\text { No. }\end{array}$ & Component Tag No. & $\begin{array}{l}\text { Component Description / Noun } \\
\text { Name }\end{array}$ & Recommended Resolution & Status & $\begin{array}{c}\text { Date } \\
\text { Completed }\end{array}$ \\
\hline N/A & & $\begin{array}{l}\text { SCHe Panel A \& B Enclosure for } \\
\text { Missile Barrier }\end{array}$ & $\begin{array}{l}\text { Perform dynamic analysis in accordance with HNF-PRO-097 to show } \\
\text { structural adequacy and displacements to prevent interaction with } \\
\text { SCHe components. Provide allowable impact force (lbf) to be } \\
\text { imparted by a 3/1 SCE to the enclosure to prevent toppling. Provide } \\
\text { allowable weights (lbs) for the } 3 / 1 \text { SCE to prevent perforation of the } \\
\text { expanded metal. }\end{array}$ & Open & \\
\hline $\mathrm{N} / \mathrm{A}$ & $\mathrm{N} / \mathrm{A}$ & PC3 stair and mezzanine & $\begin{array}{l}\text { Perform displacement calculations for the stair to verify deflection at } \\
\text { SCIC cabinet height for interaction evaluation. Provide justification } \\
\text { for using Hilti HVA anchors that are not approved for Hanford Site } \\
\text { use on PC3 components. }\end{array}$ & Open & \\
\hline N/A & $\mathrm{N} / \mathrm{A}$ & Mezzanine Handrail & $\begin{array}{l}\text { Perform structural analysis for the handrails using the mezzanine } \\
\text { ISRS to prevent interaction with MCO auxillary systems when the } \\
\text { cask is in the process bay. }\end{array}$ & Open & \\
\hline N/A & & SCHe Panel A \& B & $\begin{array}{l}\text { Revise the anchor bolt design to use Hanford Site approved type and } \\
\text { brand for PC3 installation instead of the Hilti HVA. }\end{array}$ & On-going & \\
\hline & 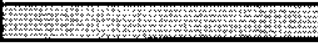 & 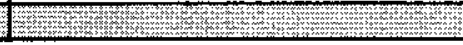 & & & \\
\hline
\end{tabular}




\begin{tabular}{|c|c|c|c|c|c|}
\hline \multicolumn{6}{|c|}{ SEISMIC $3 / 1$ EVALUATION ACTION ITEMS PUNCH LISTSEISMIC 3/1 EVALUATION ACTION ITEMS PUNCH LIST (PIPING) } \\
\hline $\begin{array}{l}\text { Sys. } \\
\text { No. }\end{array}$ & Component Tag No. & Component Description/Noun Name & Recommended Resolution & Status & Date Complete \\
\hline $07-3$ & \multicolumn{2}{|c|}{ He MSLD and Auxiliary Vacuum system (Sys. 07-3) } & & & \\
\hline $07-3$ & VPS-tbd & MSLD Line & Complete design & Open & \\
\hline 12 & \multicolumn{2}{|c|}{ Compressed and instrument air system (Sys. 12) } & & & \\
\hline 12 & IA-*01-SS-1" & Compressed Air & $\begin{array}{l}\text { Provide piping code compliance stress calculation using seismic } 3 / 1 \text { load } \\
\text { requirements }\end{array}$ & On-going & \\
\hline 12 & IA-*01-SS-1: & Instrument Air to PES Skid & $\begin{array}{l}\text { Provide piping code compliance stress calculation using seismic } 3 / 1 \text { load } \\
\text { requirements }\end{array}$ & On-going & \\
\hline 12 & IA-001-SS-1/2" & Instrument Air Supply to PWC skid & $\begin{array}{l}\text { Provide piping code compliance stress calculation using seismic } 3 / 1 \text { load } \\
\text { requirements }\end{array}$ & On-going & \\
\hline 12 & IA-002-SS-1/2" & Instrument Air Supply to PWC skid & $\begin{array}{l}\text { Provide piping code compliance stress calculation using seismic } 3 / 1 \text { load } \\
\text { requirements }\end{array}$ & On-going & \\
\hline 13 & Helium systems (Sys. 13) & & & & \\
\hline 13-1 & \multicolumn{2}{|c|}{ General Service Helium system (Sys. 13-1) } & & & \\
\hline 13-1 & He-*01-SS-1" & General Service Helium Supply on PES Skid & $\begin{array}{l}\text { Provide piping code compliance stress calculation using seismic } 3 / 1 \text { load } \\
\text { requirements }\end{array}$ & & \\
\hline 13-1 & He-*01-SS-1" & General Service Helium Supply in Bays & $\begin{array}{l}\text { Provide piping code compliance stress calculation using seismic } 3 / 1 \text { load } \\
\text { requirements }\end{array}$ & & \\
\hline 13-1 & He-101-SS-3/4" & General Service Helium Supply to Bays & $\begin{array}{l}\text { Provide piping code compliance stress calculation using seismic } 3 / \text { load } \\
\text { requirements }\end{array}$ & & \\
\hline $13-1$ & He-*01-SS-1/2" & General Service Helium Supply in Bays & $\begin{array}{l}\text { Provide piping code compliance stress calculation using seismic } 3 / 1 \text { load } \\
\text { requirements }\end{array}$ & & \\
\hline $13-1$ & He-*03-SS-1" & $\begin{array}{l}\text { General Service Helium Supply to PES Skid } 4 \text { Psig } \\
\text { Service }\end{array}$ & $\begin{array}{l}\text { Provide piping code compliance stress calculation using seismic } 3 / 1 \text { load } \\
\text { requirements }\end{array}$ & & \\
\hline $13-1$ & He-*05-SS-1/2" & GS Helium Supply to SCHe & $\begin{array}{l}\text { Provide piping code compliance stress calculation using seismic } 3 / 1 \text { load } \\
\text { requirements }\end{array}$ & On-going & \\
\hline $13-1$ & He-"06-SS-1/2" & GS Helium Supply to SCHe & $\begin{array}{l}\text { Provide piping code compliance stress calculation using seismic } 3 / 1 \text { load } \\
\text { requirements }\end{array}$ & On-going & \\
\hline $13-1$ & He-*07-ST-1/2" & GS Helium Supply to SCHe & $\begin{array}{l}\text { Provide piping code compliance stress calculation using seismic } 3 / 1 \text { load } \\
\text { requirements }\end{array}$ & On-going & \\
\hline $13-1$ & He-*08-ST-1/2" & GS Helium Supply to SCHe & $\begin{array}{l}\text { Provide piping code compliance stress calculation using seismic } 3 / 1 \text { load } \\
\text { requirements }\end{array}$ & On-going & \\
\hline $13-1$ & He-*09-ST-1/2" & GS Helium Supply to MCO DI flush line & $\begin{array}{l}\text { Provide piping code compliance stress calculation using seismic } 3 / 1 \text { load } \\
\text { requirements }\end{array}$ & On-going & \\
\hline 13-1 & $\mathrm{He}-001-\mathrm{SS}-1 "$ & GS Helium Supply - Balance of Plant & $\begin{array}{l}\text { Provide piping code compliance stress calculation using seismic } 3 / 1 \text { load } \\
\text { requirements }\end{array}$ & On-going & \\
\hline 24 & Fire protection system ( & s. 24) & & & \\
\hline
\end{tabular}




\begin{tabular}{|c|c|c|c|c|c|}
\hline & 8u! & 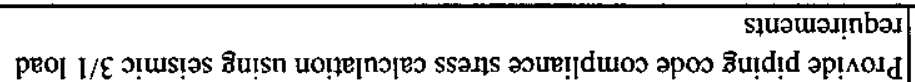 & p!Xs $\supset M d$ IR $O M d$ & ¿Z/I I-SS- $-00-3 M d$ & $1-9 t$ \\
\hline & ริบ!̣อิ-น० & 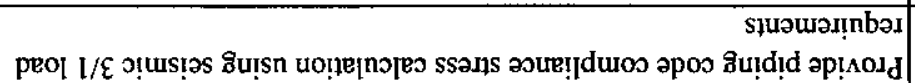 & p!ys $3 M d$ de $\supset M d$ & „Z/I I-SS-E00-כMd & $\mathrm{I}-9 \mathrm{t}$ \\
\hline & ริน!กอิ-นO & 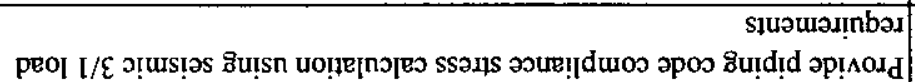 & p!Ys $5 M d$ te OMd & „Z-SS-Z00-JMd & $\lceil-9 b$ \\
\hline & 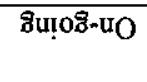 & 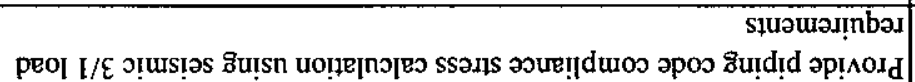 & u!edg 's & "I-SS- $\$ 0 *-J M d$ & $\mathrm{I}-9 \mathrm{t}$ \\
\hline & sิu! & 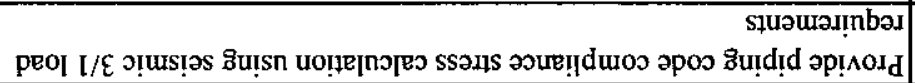 & 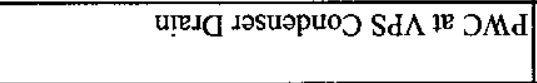 & "I-SS-Z0*-OMd & $\mathrm{I}-9 \mathrm{t}$ \\
\hline & ชีน!กชิ-บO & 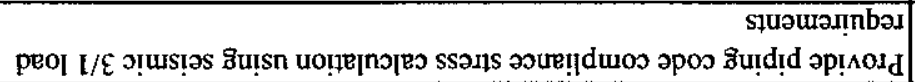 & p!YS $\supset M d$ qe $\supset M d$ & "I-SS-I00-OMd & $I-9 t$ \\
\hline & ริน!กชิ-นิO & 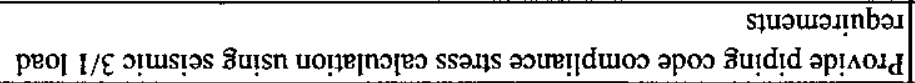 & p!ys $\supset M d$ IP $כ M d$ & "I-SS-I00-JMd & {$[-9 b$} \\
\hline & 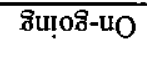 & 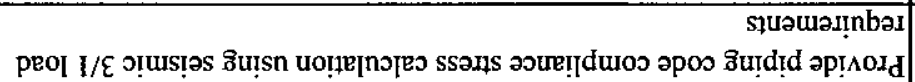 & 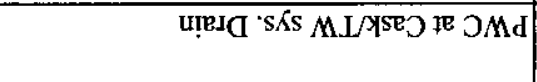 & 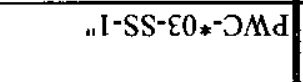 & {$[-97$} \\
\hline & & & $(\mathrm{I}-9 \mathrm{t} \cdot \mathrm{s} \Lambda \mathrm{S})$ wäls $\delta \mathrm{s}$ & 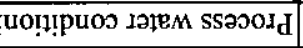 & $\mathrm{I}-9 \mathrm{t}$ \\
\hline & 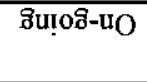 & 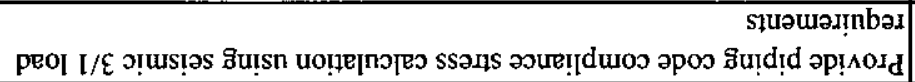 & 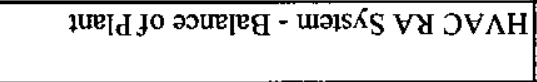 & $\forall Y$ & $\varsigma-0 \varepsilon$ \\
\hline & & & $(\varsigma-0 \varepsilon$ & 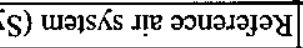 & $\varsigma-0 \varepsilon$ \\
\hline & 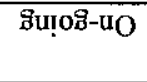 & 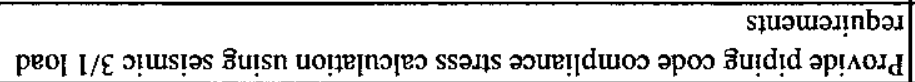 & 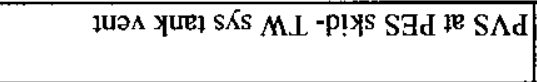 & 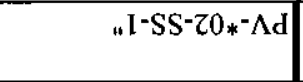 & $\varepsilon-0 \varepsilon$ \\
\hline & & & 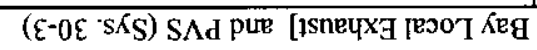 & 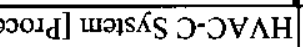 & $\mathcal{E}-0 \mathcal{E}$ \\
\hline & 8ิu!̣o $-\mathrm{u}_{\mathrm{O}}$ & 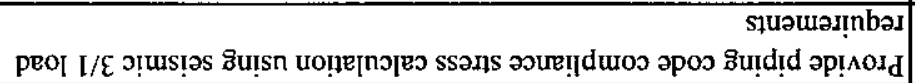 & 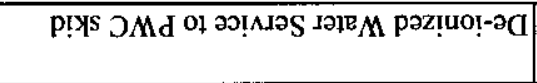 & „Z/I I-SS-tI0-IG & $\$ 2$ \\
\hline & ธิบ!̣ดภี-บO & peo| $\mathrm{l} / \mathcal{E}$ ọ̣us!๋̣s & 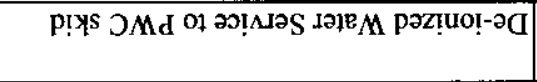 & "Z/I-SS-tI0-IC & $\varsigma Z$ \\
\hline & 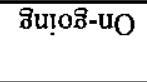 & 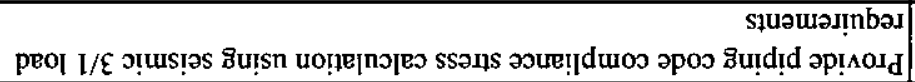 & 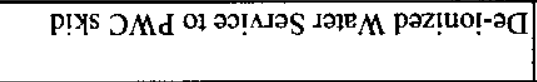 & „Z/I-SS-EI0-IG & $\varsigma \mathcal{Z}$ \\
\hline & ริแ!อชี-นO & 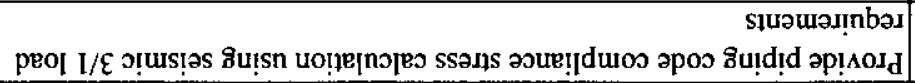 & 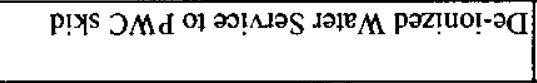 & "Z/I-SS-ZI0-IG & $\varsigma Z$ \\
\hline & รินฺุดชิ-นO & 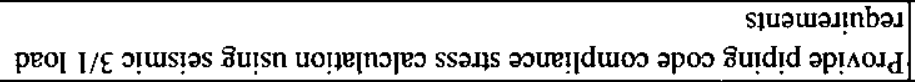 & 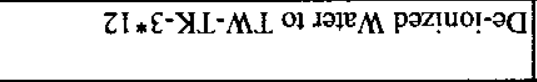 & "I-SS-Z0*-IC & $\varsigma Z$ \\
\hline & & & \multicolumn{2}{|c|}{ 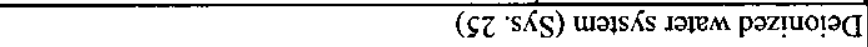 } & $\varsigma Z$ \\
\hline & 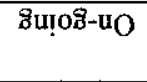 & 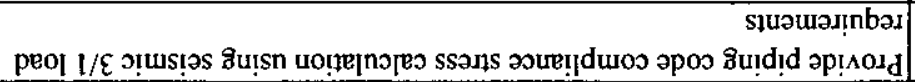 & 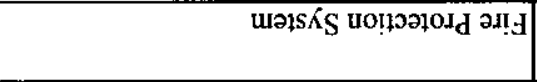 & SdH & $t z$ \\
\hline 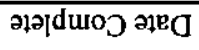 & Snְ̨EIS & uo!̣n [osay papuatuuosay & aure $\mathrm{N}$ unoN/uo!̣d!̣osəd luəuodwoว & oN $\mathrm{ate}_{\mathrm{L}}$ iuauoduo & ON \\
\hline
\end{tabular}

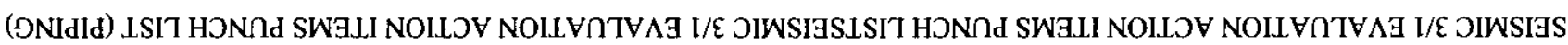




\begin{tabular}{|c|c|c|c|c|c|}
\hline \multicolumn{6}{|c|}{ SEISMIC 3/1 EVALUATION ACTION ITEMS PUNCH LISTSEISMIC 3/1 EVALUATION ACTION ITEMS PUNCH LIST (PIPING) } \\
\hline $\begin{array}{l}\text { Sys. } \\
\text { No. }\end{array}$ & Component Tag No. & Component Description/Noun Name & Recommended Resolution & Status & Date Complete \\
\hline 46-1 & PWC-005-SS-1 1/2" & PWC at PWC skid & $\begin{array}{l}\text { Provide piping code compliance stress calculation using seismic } 3 / 1 \text { load } \\
\text { requirements }\end{array}$ & On-going & \\
\hline $46-1$ & PWC-006-SS-1 1/2" & PWC at PWC skid & $\begin{array}{l}\text { Provide piping code compliance stress calculation using seismic } 3 / 1 \text { load } \\
\text { requirements }\end{array}$ & On-going & \\
\hline 46-1 & PWC-007-SS-1 1/2" & PWC at PWC skid & $\begin{array}{l}\text { Provide piping code compliance stress calculation using seismic } 3 / 1 \text { load } \\
\text { requirements }\end{array}$ & On-going & \\
\hline $46-1$ & PWC-008-SS-1 1/2" & PWC at PWC skid & $\begin{array}{l}\text { Provide piping code compliance stress calculation using seismic } 3 / 1 \text { load } \\
\text { requirements }\end{array}$ & On-going & \\
\hline 46-1 & PWC-009-SS-1 1/2" & PWC at PWC skid & $\begin{array}{l}\text { Provide piping code compliance stress calculation using seismic } 3 / 1 \text { load } \\
\text { requirements }\end{array}$ & On-going & \\
\hline 46-1 & PWC-010-SS-1" & PWC at PWC skid & $\begin{array}{l}\text { Provide piping code compliance stress calculation using seismic } 3 / 1 \text { load } \\
\text { requirements }\end{array}$ & On-going & \\
\hline $46-1$ & PWC-011-SS-1 1/2" & PWC at PWC skid and CVDF tank room & $\begin{array}{l}\text { Provide piping code compliance stress calculation using seismic } 3 / 1 \text { load } \\
\text { requirements }\end{array}$ & On-going & \\
\hline 46-1 & PWC-012-SS-1 1/2" & PWC at PWC skid & $\begin{array}{l}\text { Provide piping code compliance stress calculation using seismic } 3 / 1 \text { load } \\
\text { requirements }\end{array}$ & On-going & \\
\hline 46-1 & PWC-013-SS-2" & PWC at PWC skid & $\begin{array}{l}\text { Provide piping code compliance stress calculation using seismic } 3 / 1 \text { load } \\
\text { requirements }\end{array}$ & On-going & \\
\hline $46-1$ & PWC-014-SS-1" & PWC at PWC skid & $\begin{array}{l}\text { Provide piping code compliance stress calculation using seismic } 3 / 1 \text { load } \\
\text { requirements }\end{array}$ & On-going & \\
\hline 46-1 & PWC-015-SS-1 1/2" & PWC at PWC skid & $\begin{array}{l}\text { Provide piping code compliance stress calculation using seismic } 3 / 1 \text { load } \\
\text { requirements }\end{array}$ & On-going & \\
\hline $46-1$ & PWC-016-SS-1 1/2" & PWC in the CVDF tank room & $\begin{array}{l}\text { Provide piping code compliance stress calculation using seismic } 3 / 1 \text { load } \\
\text { requirements }\end{array}$ & On-going & \\
\hline $46 \cdot 1$ & PWC-017-SS-1" & PWC in the CVDF tank room & $\begin{array}{l}\text { Provide piping code compliance stress calculation using seismic } 3 / 1 \text { load } \\
\text { requirements }\end{array}$ & On-going & \\
\hline $46-1$ & |PWC-018-SS-1" & PWC in the CVDF tank room & $\begin{array}{l}\text { Provide piping code compliance stress calculation using seismic } 3 / 1 \text { load } \\
\text { requirements }\end{array}$ & On-going & \\
\hline $46-1$ & |PWC-019-SS-2" & PWC in the CVDF tank room & $\begin{array}{l}\text { Provide piping code compliance stress calculation using seismic } 3 / 1 \text { load } \\
\text { requirements }\end{array}$ & On-going & \\
\hline $46-1$ & PWC-020-SS-1" & PWC in the CVDF tank room & $\begin{array}{l}\text { Provide piping code compliance stress calculation using seismic } 3 / 1 \text { load } \\
\text { requirements }\end{array}$ & On-going & \\
\hline
\end{tabular}




\subsection{PERSONNEL QUALIFICATIONS AND TRAINING}

NAME: Ernesto C. Ocoma

\section{EDUCATION:}

1964 B.S. Mechanical Engineering

National University, Manila, Philippines

\section{SUMMARY OF EXPERIENCE:}

More than 31 years of experience covering broad range of engineering activities related to design and seismic evaluation for systems and components, systems preoperational testing and development of acceptance test procedures, development of design criteria for safety class systems and components, and safety analysis. Familiar with the new Department of Energy (DOE) Orders (STD-1000 series) and DOE 6430.1A Design Criteria. Project field engineering and construction duties during construction of Fast Flux Test Facility (FFTF).

Listed are several seismic evaluation projects that Mr. Ocoma has performed:

- Performed as a team member, the Seismic Category II/I evaluation by walkdown for the SCEs at the Fast Flux Test Facility during the last stage of construction and during the pre-operational testing phase.

- $\quad$ Conducted Seismic Category II/I evaluation by walkdown for the SCEs at the Fuel Storage Facility (FSF) after construction and during pre-operational testing.

- Performed as a team member, the Safety Class $3 / 1$ seismic evaluation by walkdown, the SCEs at the Plutonium Finishing Plant (PFP) Complex prior to the plant restart.

- $\quad$ Conducted Safety Class $3 / 1$ seismic evaluation by walkdown, the SCEs at Buildings 324, 325, and 327 for PNNL

- Carried out as a team member, the Safety Class 3/1 seismic evaluation by walkdown, the SCEs at the 70-foot level of Fuel Cycle Plant (FCP or FMEF).

- Performed piping systems structural evaluation for the various Hanford tank farms' Waste Transfer Systems in the $200 \mathrm{~W} \& \mathrm{E}$ Areas to provide resolution for the flammable gas explosion concern during waste transfer activities,

- Developed for Hanford Site use, the criteria and guidelines for the seismic evaluation of safety class double encased buried waste transfer systems based on ASME code and DOE standards and requirements.

- Evaluated and developed seismic upgrades for the safety class systems and components in the PFP Complex to current DOE standards and design criteria for the Safety Analysis Report compliance.

- Conducted the seismic evaluation for the sodium transfer systems to transfer the liquid sodium from the primary and secondary heat transport systems to the new storage vessels at the FFTF. 
- Directed the seismic evaluation efforts for the ventilation systems and equipment in the plutonium storage vault complex at the PFP. Developed the evaluation criteria based on DOE standards and guidelines.

- Developed for Hanford Site use, the criteria and guidelines for the seismic evaluation of new safety class piping systems and components. Developed the generic seismic evaluation procedure for existing safety class systems and components using experience data. Developed the seismic evaluation guidelines and criteria for existing non-safety class systems and components in safety class structures.

\section{TRAINING ATTENDED:}

DOE Certification Training Course on SQUG/EPRI Walkdown Screening and Seismic Evaluation on the 22 Classes of Equipment, LLNL, March 21-25, 1994

DOE Workshop on NPH Design and Evaluation Criteria for DOE Facilities, Washington D.C. April 5-8, 1993

DOE Workshop and Orientation on NPH Walkthrough Field Guide and SQUG/EPRI Seismic Evaluation, San Francisco, December 2-3, 1992

Savannah River Seismic Training on the Application of SQUG/EPRI Methodology to the Savannah River Site, March 2-6, 1992

First DOE Workshop on NPH Design and Evaluation Criteria for DOE Facilities, Albuquerque, May 9-12, 1989

\section{SELECTED PUBLICATIONS:}

1989, "Seismic Evaluation of Safety Class Systems and Components in Existing Non-Reactor Nuclear Facilities at Hanford Site," presented at Second DOE Natural Phenomena Hazards Mitigation Conference, Knoxville, TN. October 1989

1991, "Evaluation of Safety Class Systems and Components in Existing Facilities at Hanford Site," presented at ASME Pressure Vessel and Piping Conference, San Diego, June 2327,1991

1992, "Seismic Evaluation of Safety Class 3 and Non-Safety Class 4 Systems, Components, and Equipment at the Hanford Site," with D. G. Honegger, presented at ASME Pressure Vessel and Piping Conference, New Orleans, June 21-25, 1992 


\subsection{REFERENCES}

1 HNF-SD-SNF-SEL-002, Rev. 6A, Spent Nuclear Fuel Project Cold Vacuum Drying Facility Safety Equipment List, Numatec Hanford Corporation, Richland, Washington.

2 HNF-SD-GN-DGS-30006, Rev. 2, Guidelines for Assessing the Seismic Adequacy of Existing Performance Category Equipment at the Hanford Site, Fluor Daniel Hanford, Inc., Richland, Washington.

3 Documented Analyses identified in Tables A-1A, A-2A, and A-4A under the column 'Seismic Calculation References'.

4 HNF-PRO-097, Rev. O, Engineering Design and Evaluation, Fluor Daniel Hanford, Inc., Richland, Washington.

$5 \quad$ NFPA 13, 1991, Standards for the Installation of Sprinkler System, National Fire Protection Agency, Quincy, Massachusetts.

6 ICBO, 1994, Uniform Building Code, International Conference of Building Officials, Whittier, California.

7 SNF-4148, Rev. OA, Spent Nuclear Fuel Project Cold Vacuum Drying Facility Master Equipment List, Numatec Hanford Corporation, Richland, Washington. 
HNF-4291, Rev. 0

\subsection{CALCULATIONS}




\section{3/1 EVALUATIONS}

Client

Subject CVDF SEISMIC 3/1 EVALUATION

WO/Job No.

Evaluate pipe supports for PWC-001-SS-1: (Ref. H-1-8225, 82231)

Supports are 2-way, $Y \& Z$ direction restraint ( $X$-direction which is north/south is not restrained). Pipe is 1 " sch 160 ss

For carbon steel pipe, lb./ft $\quad{ }^{w}$ pipe $:=2.844 \cdot \frac{\mathrm{lb}}{\mathrm{ft}} \cdot(1.02)$ for SS material, increase wt of CS by $2 \%$

$$
w_{\text {pipe }}=2.9^{\circ} \frac{\mathrm{lb}}{\mathrm{ft}}
$$

Wt. of water in 1"pipe, $\mathrm{lb} / \mathrm{ft} \quad \mathrm{w}_{\mathrm{wtr}}:=0.2261 \cdot \frac{\mathrm{lb}}{\mathrm{ft}}$

Unsupported span length is $6^{\prime} 6^{\prime \prime} . \quad L:=6.5 \cdot \mathrm{ft}$

Total weight, $\quad \mathrm{W}_{\mathrm{p}}:=\left(\mathrm{w}_{\text {pipe }}+\mathrm{w}_{\mathrm{wtr}}\right) \cdot \mathrm{L} \quad \mathrm{w}_{\mathrm{p}}=20.33 \mathrm{lb} \quad$ (Use $50 \mathrm{lb}$ )

$$
\mathrm{W}_{\mathrm{p}}:=50 \cdot \mathrm{lb}
$$

From WHC-SD-GN-DGS-30006, Table 2-3: $\quad \mathrm{A}_{\mathrm{h}}:=3.12$

$$
\begin{array}{ll}
\mathrm{f}_{\mathrm{y}}:=\mathrm{W}_{\mathrm{p}} \cdot \mathrm{A}_{\mathrm{h}} \cdot(0.67) & \mathrm{f}_{\mathrm{y}}=104.52 \mathrm{lb} \\
\mathrm{f}_{\mathrm{z}}:=\mathrm{W}_{\mathrm{p}} \cdot \mathrm{A}_{\mathrm{h}} & \mathrm{f}_{\mathrm{z}}=156 \mathrm{lb}
\end{array}
$$

Check U-bolt for 1" pipe. Allowable from H-4-36511, sht 231

$$
F_{y}:=1220 \cdot 1 b \quad F_{z}:=636 \cdot 1 b
$$

Interaction $I R_{\text {ubolt }}:=\frac{f_{y}}{F_{y}}+\frac{f_{z}}{F_{z}} \quad I R$ ubolt $=0.33 \quad$ (less than 1.0 therefore $U$-bolt is $O K$ )

Check anchor bolt HKBII 1/2" $\times 2$ 1/4" embed. $\mathrm{f}^{\prime}=4000 \mathrm{psi}$

$$
F_{T}:=1360 \cdot 1 \mathrm{~b} \text { allowable tension capacity } \quad F_{V}:=1470 \cdot 1 b \text { allowable shear capacity }
$$

$$
\begin{array}{lll}
\text { Tension, } T & T:=\frac{f_{y} \cdot(4)}{6 \cdot(2)}+\frac{f_{z}}{4} & T=73.84 \mathrm{lb} \\
\text { Shear, } V & V:=\frac{f_{y}}{4} & V=26.13 \mathrm{lb}
\end{array}
$$

Interaction $\quad \mathrm{IR}_{\text {abolt }}:=\frac{\mathrm{T}}{\mathrm{F}_{\mathrm{T}}}+\frac{\mathrm{V}}{\mathrm{F}_{\mathrm{V}}} \quad \mathrm{IR}_{\text {abolt }}=0.07 \quad$ (less than 1.0 therefore anchor bolt is $\mathrm{OK}$ ) 


\section{3/1 EVALUATIONS}

Client

Subject CVDF SEISMIC 3/1 EVALUATION

Location $100 \mathrm{~K}$
WO/Job No.

Date $4 / 2 / 99$
$\& 0$

By EC Ocoma

Check anchorage for Fire Protection System Supports - 1st Floor

Note: The $3 / 1$ criteria use $3.12 \mathrm{~g}$ seismic lateral acceleration while NFPA 13 use $0.50 \mathrm{~g}$.

A partial model of the system for the first floor shown in H-1-82237 was analyzed (see Appendix A) to verify the structural adequacy of the supports.

Check the transverse sway brace at node $\mathrm{A} 07$.

Brace is assumed as type $\mathrm{H} 7$ per drawing $\mathrm{H}-1-82240$.

The calculated tension load at node A07 from piping output is 2724 lbs.

From Grinnell catalogue, for fitting Fig. 112 and 113, the allowable load is $950 \mathrm{lbs}<2724 \mathrm{lbs}$ (No Good)

Tension capacity of $1 / 2 "$ HKBII $\times 21 / 4$ embed. in 4000 psi concrete $=1360 \mathrm{lbs}<2724 \mathrm{lbs}$. (No Good) x $31 / 2$ embed.

$=2250 \mathrm{lbs}<2724 \mathrm{lbs}$ NO Good

Pipe clamp Grinnell Fig. 212 (4"dia.) capacity = 1040 lbs. $<$ than 2724 lbs. No Good.

Add more braces to resolve the overloading. 


\section{3/1 EVALUATIONS}

Client

Subject CVDF SEISMIC 3/1 EVALUATION

\section{Monitoring and Control System I/O Panel GFE CP *01}

Check anchorage attachment of the Panel to the concrete floor to prevent potential seismic interaction with the SCHe Panel B caused by overturning or toppling. The SCHe Panel is located on the south side of the 1/O panel therefore only the overturning in the $+Z$ direction (south) will be evaluated.

\section{WEIGHTS}

Panel has $12 \mathrm{ga}$. thk. enclosure

(1) enc $:=3.80 \cdot \frac{\mathrm{lb}}{\mathrm{ft}^{2}} \quad \mathrm{t}_{12 \mathrm{ga}}:=0.093 \cdot$ in

\section{Area of Enclosure}

$A_{\text {enc }}:=\frac{(12 \cdot \mathrm{in} \cdot(74 \cdot \mathrm{in})+74 \cdot \mathrm{in} \cdot(72 \cdot \mathrm{in})+12 \cdot \mathrm{in} \cdot(72 \cdot \mathrm{in})) 2}{144 \cdot \frac{\mathrm{in}^{2}}{\mathrm{ft}^{2}}}$

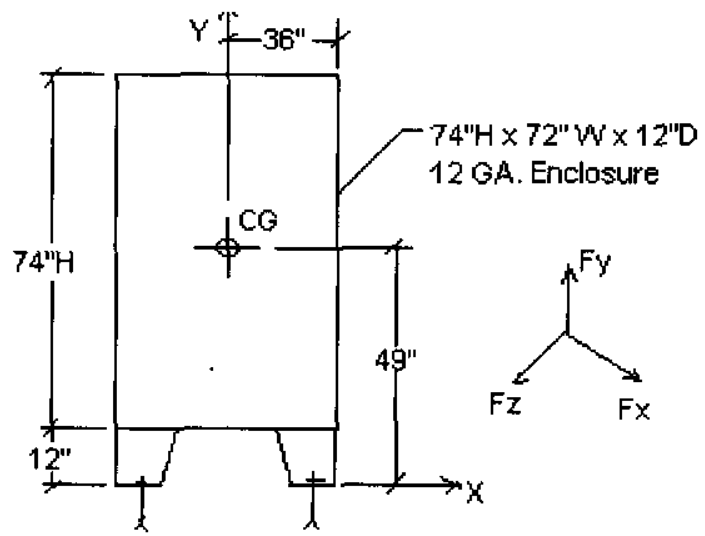

$A_{\text {enc }}=98.33 \mathrm{ft}^{2}$

\section{EAST ELEVATION}

Weight of Enclosure

$\mathrm{W}_{\text {wt.enc }}:=\mathrm{A}_{\mathrm{enc}} \mathrm{c}^{(\omega)}$ enc

$\mathrm{W}_{\text {wt.enc }}=373.67 \mathrm{lb}$

Removable $10 \mathrm{ga}$. panel inside the enclosure

Panel length: $L_{1}:=69.7$ in

Panel width: $\quad \mathrm{W}_{1}:=67.9 \cdot$ in

Panel unit wt. ${ }^{(1)}$ panel $:=5.02 \cdot \frac{\mathrm{lb}}{\mathrm{ft}^{2}}$

Weight of Panel, $W_{\text {wt.panel }}:=\mathrm{L}_{1} \cdot \mathrm{W}_{1}{ }^{\cdot(0)}$ panel

$$
\mathrm{W}_{\text {wt.panel }}=164.98 \mathrm{lb}
$$

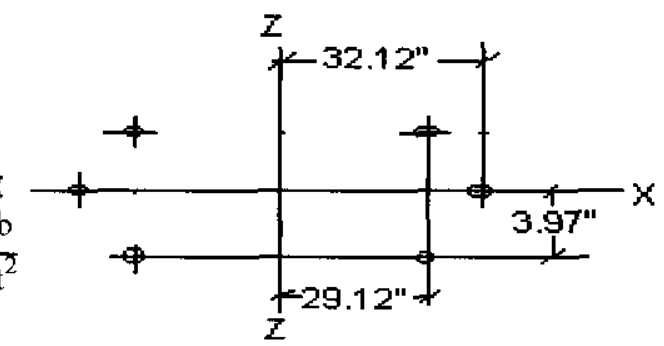

ANCHOR BOLT PATTERN 3/8" HKB II, 4 1/4" Embed. 4000 psi concrete

Assume cummulative weight of stiffeners, bolts, nuts,clamps, center post, and stands:

$$
\mathrm{W}_{\text {wt.misc }}:=30 \cdot \mathrm{lb}
$$

Assume weight of equipment inside the cabinet:

$$
\begin{aligned}
& \mathrm{W}_{\text {wt.equip }}:=30 \cdot \mathrm{lb} \\
& \mathrm{W}_{\text {wt.total }}:=\mathrm{w}_{\text {wt.enc }}+\mathrm{W}_{\text {wt.panel }}+\mathrm{W}_{\text {wt.misc }}+\mathrm{W}_{\text {wt.equip }} \\
& \mathrm{W}_{\text {wt.total }}=598.65 \mathrm{lb}
\end{aligned}
$$




\section{3/1 EVALUATIONS}

Client

Subject CVDF SEISMIC 3/1 EVALUATION
WO/Job No.

Date $6 / 7 / 9 p$

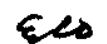

By EC Ocoma

Location $100 \mathrm{~K}$

Cabinet is located at grade. Assume cabinet is flexible.

From Reference 8.2, Table 2-3:

$A_{h}:=0.78 \quad$ Horizontal seismic acceleration per SD-30006. No value was given for vertical seismic accel.

From Ref. 8.4, Table 6, the horiz. and vertical peak ground accelerations are $0.26 \mathrm{~g}$ and $0.18 \mathrm{~g}$ respectively.

$$
\text { Ratio }:=\frac{.18}{.26}
$$

$$
\begin{array}{ll}
A_{V}:=R a t i o \cdot A_{h} & \text { Vertical seismic acceleration } \\
A_{V}=0.54 &
\end{array}
$$

Assume C.G. is located at mid-height $\quad \mathrm{H}_{\mathrm{c} . \mathrm{g} .}:=49$.in

\section{LOADS}

$$
\begin{aligned}
& \mathrm{F}_{\mathrm{X}}:=\mathrm{A}_{\mathrm{h}} \cdot \mathrm{W}_{\text {wt.total }} \quad \mathrm{F}_{\mathrm{X}}=466.95 \mathrm{lb} \quad \mathrm{F}_{\mathrm{Z}}:=\mathrm{A}_{\mathrm{h}} \cdot \mathrm{W}_{\text {wt.total }} \quad \mathrm{F}_{\mathrm{Z}}=466.95 \mathrm{lb} \\
& F_{y}:=A_{V} \cdot W_{\text {wt.total }} \quad F_{y}=323.27 \mathrm{lb}
\end{aligned}
$$

ANCHOR BOLT ALLOWABLE CAPACITIES (From ICBO Report ER-4627, dated July 1, 1996)

Tension $\quad T_{A}:=1350 \cdot \mathrm{lb} \quad$ (with special inspection during installation per ICBO)

Shear $\quad \mathrm{V}_{\mathrm{A}}:=1111 \mathrm{lb} \quad$ (with special inspection during installation per ICBO)

\section{CHECK OVERTURNING IN THE + Z DIRECTION:}

In this condition, the outermost row of bolts (2) are in tension

$$
\begin{aligned}
& D_{z 1}:=6 \cdot \text { in } \\
& D_{z 2}:=9.97 \cdot \text { in }
\end{aligned}
$$

\section{Resisting Moment: RM}

$$
\begin{aligned}
& \mathrm{RM}:=\mathrm{W}_{\text {wt.total }} \cdot \mathrm{D}_{\mathrm{z} 1} \\
& \mathrm{RM}=299.33 \mathrm{lb} \cdot \mathrm{ft}
\end{aligned}
$$

Overturning Moment: OM (100\%-40\%-40\% combination)

$$
\begin{aligned}
& \mathrm{OM}:=\mathrm{F}_{\mathrm{z}} \cdot \mathrm{H}_{\text {c.g. }}+\mathrm{F}_{\mathrm{y}} \cdot \mathrm{D}_{\mathrm{zl}} \cdot(0.40) \\
& \mathrm{OM}=1.97 \cdot 10^{3} \mathrm{lb} \cdot \mathrm{ft}
\end{aligned}
$$

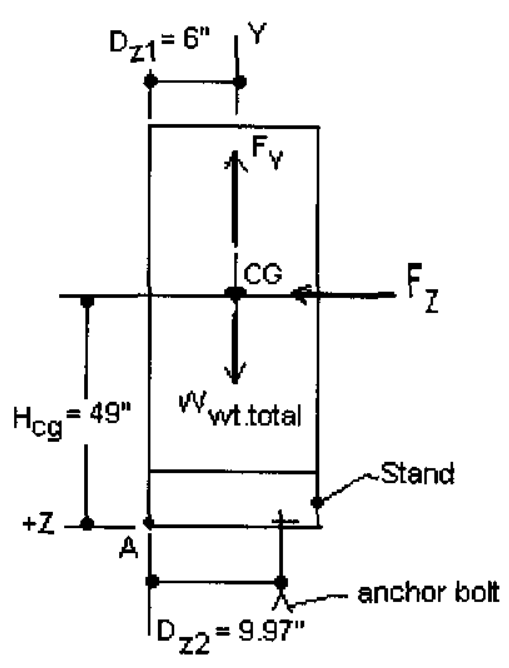




\section{3/1 EVALUATIONS}

Client

WO/Job No.

Date $\varphi / 7 / q \varphi$

$\varepsilon \infty$

By EC Ocoma

Subject CVDF SEISMIC 3/1 EVALUATION

Location $100 \mathrm{~K}$

Net Overturning Moment: $O M_{\text {net }}$

$\mathrm{OM}_{\text {net }}:=\mathrm{OM}-\mathrm{RM} \quad \mathrm{OM}$ net $=1.67 \cdot 10^{3} \mathrm{lb} \cdot \mathrm{ft}$

Net Tension load on outer row bolts

$\mathrm{N}_{\text {bolt.ten }}:=2 \quad$ Number of bolts under tension (outermost row) for overturning only.

$T_{\text {overturn }}:=\frac{O M_{\text {net }}}{D_{z 2} \cdot N_{\text {bolt.ten }}}$

$\mathrm{T}_{\text {overturn }}=1.01 \cdot 10^{3} \mathrm{lb} \quad$ Less than the allowable tension of $1350 \mathrm{lbs}$. The 2 bolts that are under tension will not pullout, therefore the anchor bolts are OK.

Check weld between bottom of cabinet and stand.

Reference : Design of Welded Structures by Blodgett

Area of weld, $\quad A_{\text {weld }}:=4 \cdot \mathrm{in}+3 \cdot \operatorname{in} \cdot(2)$

$$
A_{\text {weld }}=0.83 \mathrm{ft} \quad \text { Use } A_{\text {weld }}:=3 \cdot \text { in }
$$

Vertical load per stand, $F_{y}$ stand

$$
\mathrm{F}_{y . \text { stand }}:=\mathrm{T}_{\text {overturn }} \quad \mathrm{F}_{\text {y.stand }}=1.0 \mathrm{I} \cdot 10^{3} \mathrm{lb}
$$

Force on weld: $f_{\text {weld }}$

$$
\begin{aligned}
f_{\text {weld }}: & =\frac{F_{z}}{A_{\text {weld }}} \\
f_{\text {weld }} & =155.65 \circ \frac{\mathrm{lb}}{\mathrm{in}}
\end{aligned}
$$

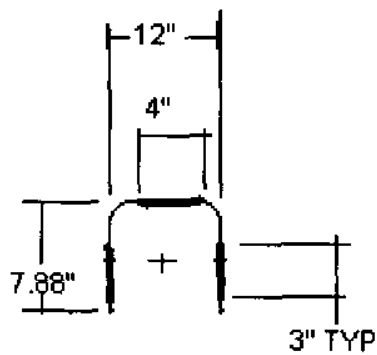

Weld lengths are field data. Weld size is larger than base metal thickness. Assume leg of fillet weld is equal to base metal thickness $\left(0.093^{\prime \prime}\right)$. Assume base metal is CS ASTM A36 Assume $\mathrm{E} 60$ weld rod.

$$
\begin{aligned}
& \mathrm{ULT}_{\text {basemetal }}:=58000 \cdot \frac{\mathrm{lb}}{\mathrm{in}^{2}} \\
& \text { ULT }_{\text {weldrod }}:=60000 \cdot \frac{\mathrm{lb}}{\mathrm{in}^{2}}
\end{aligned}
$$

$$
\begin{aligned}
& \mathrm{F}_{\mathrm{W}}:=(0.3) \cdot \mathrm{ULT}_{\text {basemetal }} \cdot(.707) \cdot \mathrm{t}_{12 \mathrm{ga}} \\
& \mathrm{F}_{\mathrm{W}}=1.14 \cdot 10^{3}{ }^{3} \frac{\mathrm{lb}}{\mathrm{in}}
\end{aligned}
$$

\section{Margin of Safety}

$$
\begin{aligned}
& M S_{\text {weld }}:=\frac{F W}{f_{\text {weld }}}-1 \\
& M S_{\text {weld }}=6.35 \quad>\text { than } 0.0 \text {, therefore weld is OK. }
\end{aligned}
$$




\section{3/1 EVALUATIONS}

Client

Subject CVDF SEISMIC 3/1 EVALUATION

WOIJob No. $\xi \infty$

By EC Ocoma

Location $100 \mathrm{~K}$

Check base plate of stand for overturning:

Width of base, $\quad b$ width $:=7.88 \cdot$ in

Plate thickness, $\mathrm{t}$ plate $:=0.093 \cdot$ in

Assume plate is ASTM A36

$$
F_{y} \cdot A 36:=36000 \cdot \frac{\mathrm{lb}}{\mathrm{in}^{2}}
$$

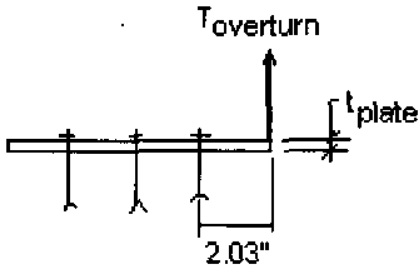

$$
\begin{aligned}
& F_{\text {b.plate }}:=0.75 \cdot \mathrm{F}_{\text {y.A36 }} \cdot(1.33) \quad \text { (Allowable bending) } \\
& F_{\text {b.plate }}=5.17 \cdot 10^{6} \frac{\mathrm{lb}}{\mathrm{ft}^{2}}
\end{aligned}
$$

Calculate plate thickness required, $t_{\text {platereqd }}$

$$
\begin{aligned}
& \mathrm{t}_{\text {platereqd }}:=\sqrt{\frac{6 \cdot\left(\mathrm{T}_{\text {overturn }}\right) \cdot(2.03 \cdot \mathrm{in})}{\mathrm{b}_{\text {width }} \mathrm{F}_{\text {b.plate }}}} \\
& { }^{\mathrm{t}} \text { platereqd }=0.21 \text { in }>\text { than } \mathrm{t}_{\text {plate }}=0.09 \text { \% in No Good }
\end{aligned}
$$

\section{Margin of Safety:}

$$
\text { MS } \text { plate }:=\frac{{ }^{t} \text { plate }}{t \text { platereqd }}-1 \quad \text { MS plate }=-0.55 \quad \text { (Negative Margine of Safety is not acceptable) }
$$

Calculate bending stress: $f_{b}$

$$
\begin{aligned}
f_{b}:=\frac{6 \cdot T \text { overturn } \cdot(2.03 \cdot i n)}{b_{\text {width }} \cdot\left({ }^{t} \text { plate }\right)^{2}} \\
f_{b}=1.8 \cdot 10^{5} \frac{\mathrm{lb}}{\mathrm{in}^{2}} \quad \gg>\text { greater than } 36000 \text { psi yield. No good. }
\end{aligned}
$$

The base plate will yield when subjected to the seismic load in the z-direction which is towards the SCHe Panel. The I/O Panel can potentially interact with the SCHe Panel. Provide additional restraint at the top of the I/O Panel to prevent toppling. The restraint may be in the configuration of a cable threaded through the eye of the I/O Panel lifting lugs (located on top) and the ends attached to the wall using anchor bolts. The cable shall not be tight to prevent the wall displacement from being transferred to the Panel. 


\section{3/1 EVALUATIONS}

Client

Subject CVDF SEISMIC 3/1 EVALUATION

Wo/Job No

By EC Ocoma

Location $100 \mathrm{~K}$

\section{CONDENSATE COLLECTION TANK}

Reference : $\mathrm{H}-1-82225$

The support type is a trapeze with $3 / 8^{\prime \prime}$ dia threaded rods for vertical members. The tank capacity is 15 gallons. The empty weight is $51 \mathrm{lbs}$. The weight of condensate, if tank is full equals $125 \mathrm{lbs}$. Total weight equals $176 \mathrm{lbs}$. The hanger rods are attached to the mezzanine structural members at the top and to unistrut channels at the bottom with double nuts. The rod connections are considered in Reference 2 as fixed rotation or not pinned when using double nuts. The rods are ASTM A36 all thread.

$$
\begin{aligned}
& \mathrm{d}_{\text {rod }}:=0.298 \cdot \mathrm{in} \quad \mathrm{h}_{\text {rod }}:=14 \cdot \mathrm{in} \quad \mathrm{L}_{\text {uni }}:=14 \cdot \mathrm{in} \\
& \mathrm{F}_{\mathrm{y} . \mathrm{rod}}:=36000 \cdot \frac{\mathrm{lb}}{\mathrm{in}^{2}} \quad \mathrm{~F}_{\text {allow.rod }}:=0.75 \cdot(\mathrm{F} \text { y.rod }) \quad \mathrm{F}_{\text {allow.rod }}=2.7 \cdot 10^{4} \cdot \frac{\mathrm{lb}}{\mathrm{in}^{2}}
\end{aligned}
$$

$\mathrm{w}_{\mathrm{p}}:=\frac{176 \cdot \mathrm{lb}}{2} \quad \mathrm{w}_{\mathrm{p}}=88 \mathrm{lb}$
$\mathrm{A}_{\text {hnew }}:=3.12$
A $_{\text {vnew }}:=\frac{2}{3} \cdot\left(A_{\text {hnew }}\right)$
$\mathrm{A}_{\text {vnew }}=2.08$
(Seismic accel. per Ref. 2)

Support is idealized as Case 41/8 in Reference 4.

Moment of Inertia

$$
\begin{aligned}
& \mathrm{J}_{1}:=\frac{\pi \cdot \mathrm{d}_{\text {rod }}^{4}}{64} \quad \mathrm{~J}_{1}=3.87 \cdot 10^{-4} \operatorname{oin}^{4} \\
& \mathrm{~J}_{2}:=0.185 \cdot \mathrm{in}^{4} \quad \text { (from Unistrut catalogue) } \\
& \mathrm{k}:=\frac{\mathrm{J}_{2}}{\mathrm{~J}_{1}} \cdot \frac{\mathrm{h}_{\text {rod }}}{\mathrm{L} \text { uni }} \quad \mathrm{k}=477.9 \\
& \mathrm{~N}_{1}:=\mathrm{k}+2 \\
& \mathrm{~N}_{2}:=6 \cdot \mathrm{k}+1 \quad \mathrm{~N}_{1}=479.9
\end{aligned}
$$

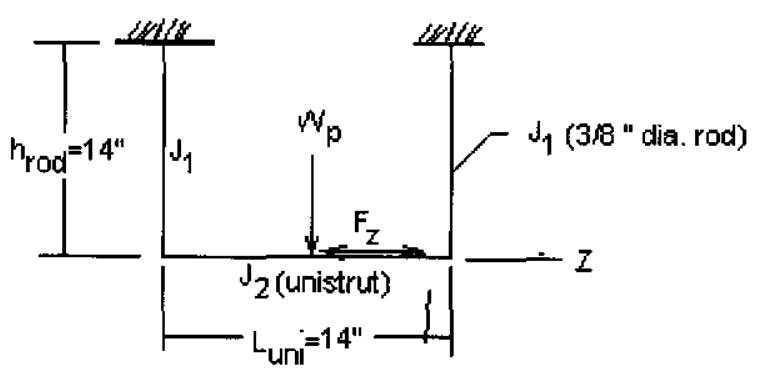

Check rod bending in $\mathrm{Z}$ - direction

$$
\begin{aligned}
& \mathrm{F}_{\mathrm{z}}:=\frac{\mathrm{W}_{\mathrm{p}} \cdot \mathrm{A}_{\text {hnew }}}{2} \\
& \mathrm{~F}_{\mathrm{z}}=137.28 \mathrm{lb} \\
& \mathrm{M}_{\mathrm{Az}}:=\frac{\mathrm{F}_{\mathrm{z}} \cdot \mathrm{h} \operatorname{rod}}{2} \cdot\left(\frac{3 \cdot \mathrm{k}+1}{\mathrm{~N}_{2}}\right) \\
& \mathrm{M}_{\mathrm{Az}}=40.05 \mathrm{lb} \cdot \mathrm{ft}
\end{aligned}
$$




\section{3/1 EVALUATIONS}

Client

Subject CVDF SEISMIC 3/1 EVALUATION

WO/Job No.

Date $6 / 7 / 99$ $\varepsilon \infty$

By EC Ocoma

Location $100 \mathrm{~K}$

Bolt tensile stress area, from AISC Manual

$$
A_{\text {rod }}:=0.078 \cdot \mathrm{in}^{2} \quad N:=\frac{16}{\text { in }} \quad \text { thread/in. }
$$

$\mathrm{D}_{\text {rod }}:=\frac{.9743}{\mathrm{~N}}+\sqrt{\frac{\mathrm{A}_{\text {rod }}}{.7854}} \quad \mathrm{D}_{\text {rod }}=0.38$ oin

Section Modulus of rod

$\mathrm{S}_{\mathrm{z}}:=.098175 \cdot \mathrm{D}_{\mathrm{rod}^{3}} \mathrm{~S}_{\mathrm{z}}=5.22 \cdot 10^{-3} \operatorname{oin}^{3}$

Bending stress:

$f_{b z}:=\frac{M_{A z}}{S_{z}} \quad f_{b z}=9.21 \cdot 10^{4} \circ \frac{\mathrm{lb}}{\mathrm{in}^{2}}$

Margin of Safety, $\quad$ MS $:=\frac{F \text { allow.rod }(1.33)}{f_{b z}}-1$

$$
\text { MS }=-0.61 \text { Negative margin of safety --- NO GOOD }
$$

Provide lateral restraints or fall protection cable or relocate Condensate Tank outside the zone of influence of the SCHe tubing and Panel (approximately 4 feet horizontal distance). 


\section{3/1 EVALUATIONS}

Client

Subject CVDF SEISMIC 3/1 EVALUATION

WO/Job No

Date $C / 7 / q \varphi$
80

By EC Ocoma

Location 100K

\section{SEISMIC ZONE OF INFLUENCE}

The seismic zone of influence for falling items (source) is primarily applied to items that are located above grade. The calculation to establish the zone requires the horizontal peak seismic acceleration $(\mathrm{g})$ at the elevation point and the corresponding frequency from the in-structure response spectra. There are no building in-structure response spectra that are generated for various elevations up to the roof, where the peak acceleration can be obtained from. The peak horizontal acceleration that will be used, as established in Reference 2, for flexible components located above grade that are potential interaction items is $3.12 \mathrm{~g}$. The frequency range at the peak of the spectra for $5 \%$ damping will be taken from Table 6 of HNF-PRO-97. The frequency is $5 \mathrm{~Hz}$. In this evaluation, the source will be assumed as a horizontal projectile.

From HWS - 1386, Rev. 12, velocity Vo is:

$$
\begin{aligned}
& \mathrm{f}_{\mathrm{hz}}:=\frac{5}{\mathrm{sec}} \quad A_{\text {hnew }}:=3.12 \cdot \mathrm{g} \\
& \mathrm{V}_{\mathrm{o}}:=\frac{\mathrm{A}_{\text {hnew }}}{2 \cdot \pi \cdot \mathrm{f}_{\mathrm{hz}}} \quad \mathrm{V}_{\mathrm{o}}=2.180^{\circ} \mathrm{mi} \\
& \text { Use } \quad \mathrm{V}_{\mathrm{o}}:=4 \cdot \frac{\mathrm{ft}}{\mathrm{sec}} \quad \text { for conservatism }
\end{aligned}
$$

\section{Governing Equations:}

For a horizontal projectile, the horizontal $(R)$ and the vertical $(H)$ distance travelled at any time $\left(t_{\text {sec }}\right)$ is calculated as follows:

$$
\begin{aligned}
& R:=V_{0} \cdot t \sec \\
& H:=-\frac{1}{2} \cdot g \cdot t \sec ^{2}
\end{aligned}
$$

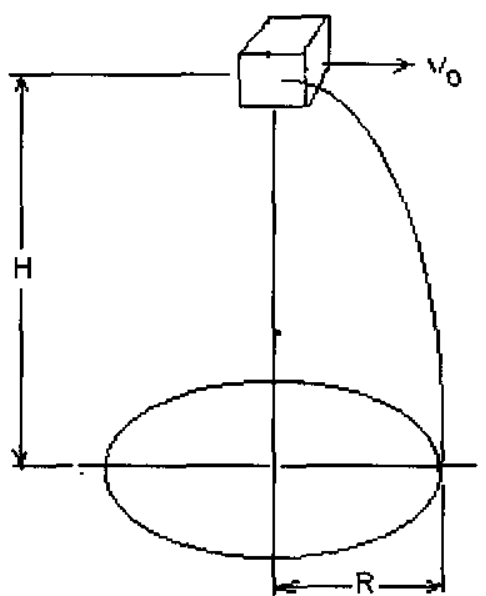

$V_{0}=$ initial horizontal velocity $\mathrm{H}=$ Height of source from target $\mathrm{R}=$ Horizontal distance travelled by source 
NUMATEC HANFORD COMPANY

\section{3/1 EVALUATIONS}

Client

Subject CVDF SEISMIC 3/1 EVALUATION

WOlJob No.
Date $6 / 7 / 99$ $\varepsilon \infty$

By EC Ocoma

Location $100 \mathrm{~K}$

Time of flight, $t_{\mathrm{sec}}$

$$
\mathrm{t}_{\mathrm{sec}}:=\left[\begin{array}{c}
0 \\
.25 \\
.5 \\
.75 \\
1 \\
1.25 \\
1.5 \\
1.75 \\
2 . \\
2.25
\end{array}\right] \cdot \mathrm{sec}
$$

Horizontal distance travelled by the source in $t_{\text {sec }}$

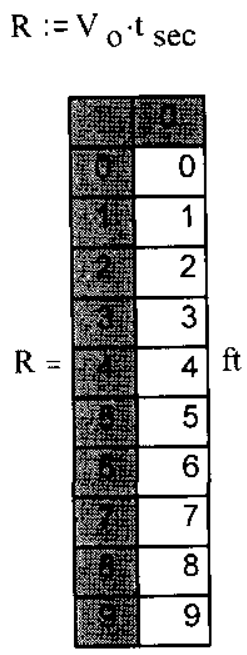

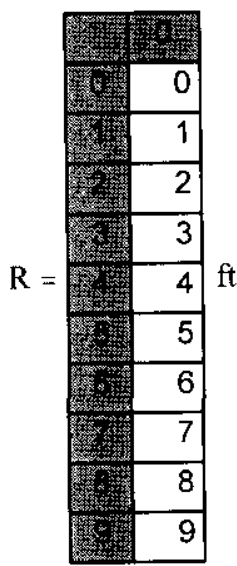

Vertical distance travelled by the source in $t_{\text {sec }}$

$$
\begin{aligned}
& H_{h t}:=\frac{-1}{2} \cdot g \cdot\left(t_{\text {sec }}\right)^{2}
\end{aligned}
$$

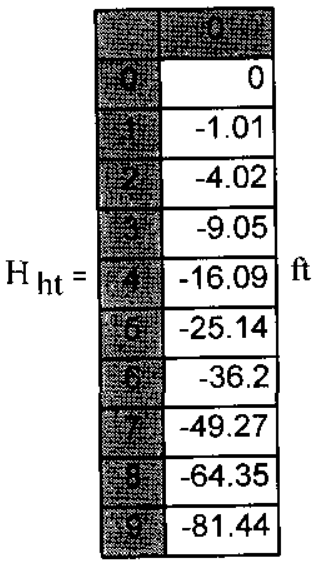


HNF-4291

REV. $O$

Figure 4.1: SEISMIC ZONE OF INFLUENCE CVDF PROCESS BAYS

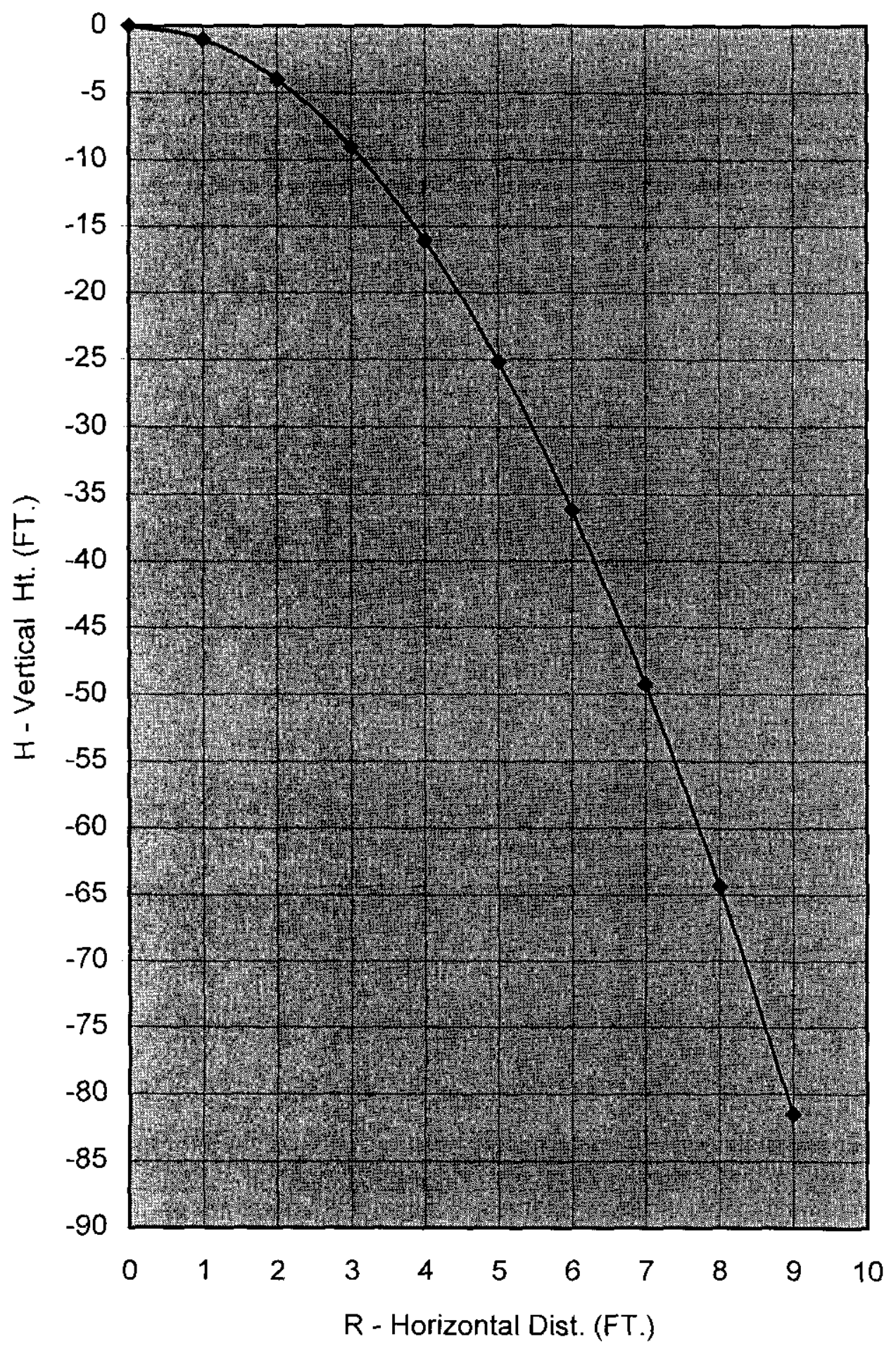

PAGE 25 
Figure 4.1: SEISMIC ZONE OF INFLUENCE CVDF PROCESS BAYS

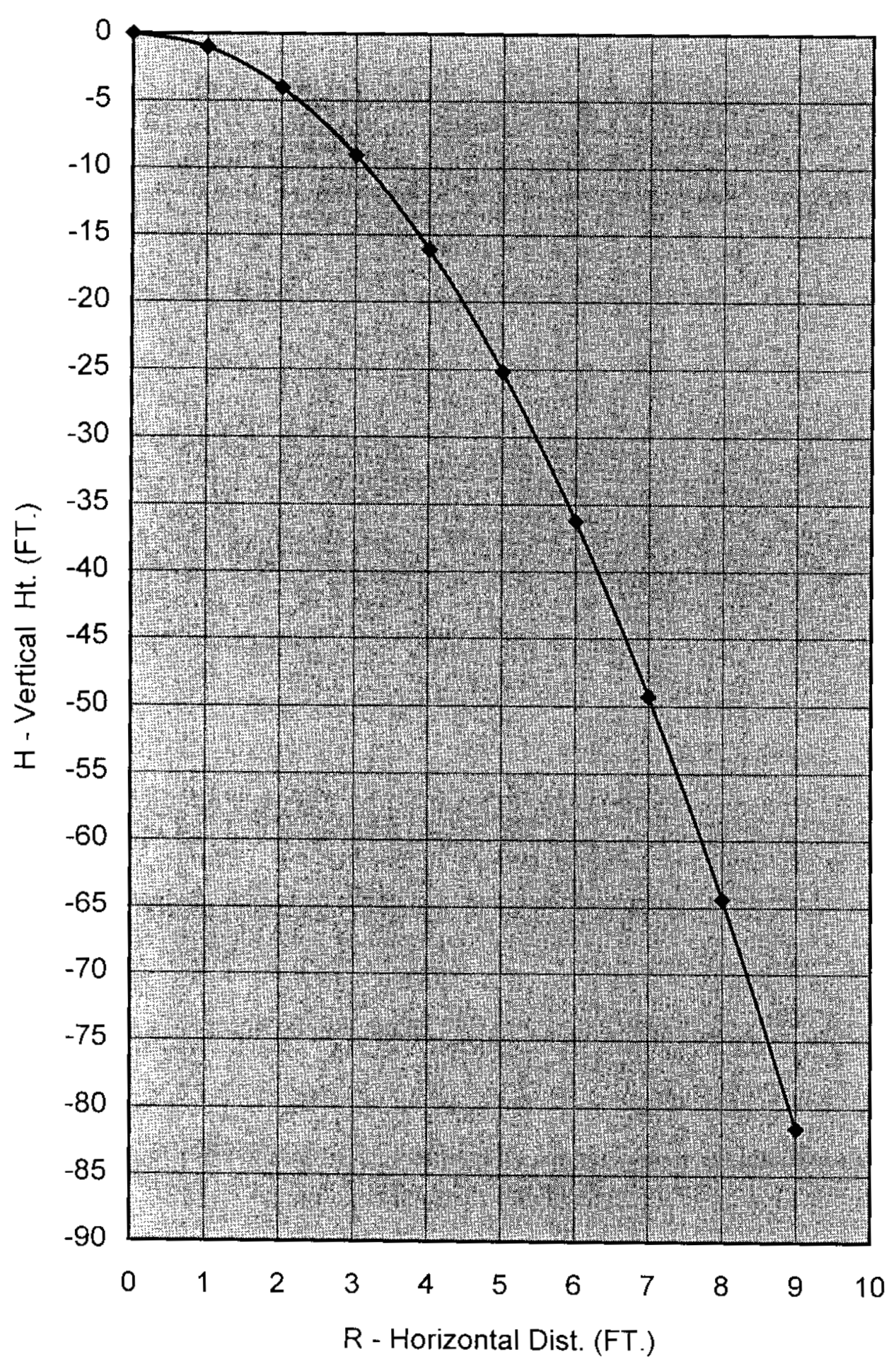




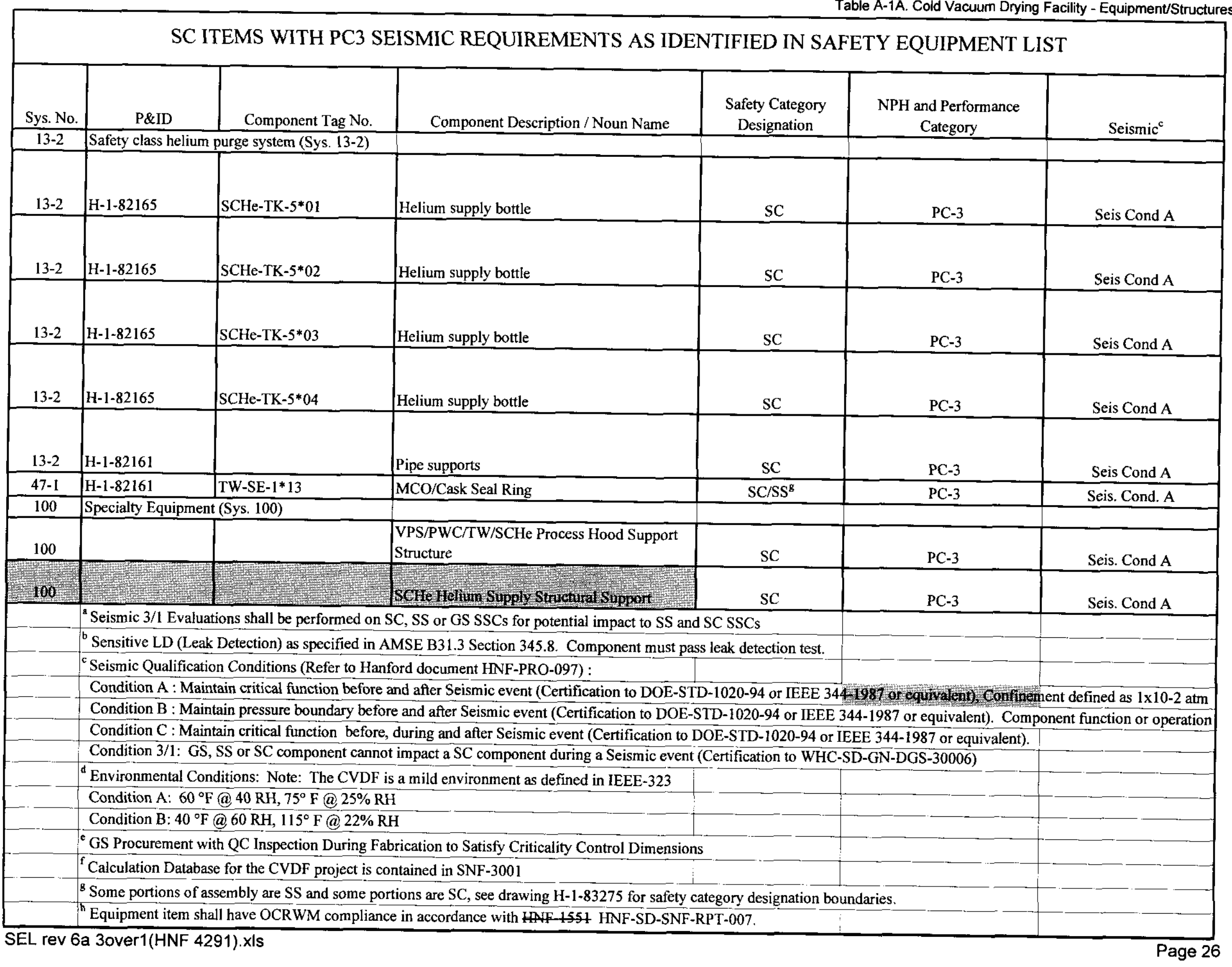


HNF-4291, Rev, 0

Table A-2A. Cold Vacuum Drying Facility - Piping

\begin{tabular}{|c|c|c|c|c|c|c|}
\hline \multicolumn{7}{|c|}{ SC ITEMS WITH PC3 SEISMIC REQUIREMENTS AS IDENTIFIED IN SAFETY EQUIPMENT LIST } \\
\hline Sys. No. & P\&ID & Component Tag No. & Component Description/Noun Name & Safety Category Designation & $\begin{array}{l}\text { NPH and Performance } \\
\text { Category }\end{array}$ & Seismic $^{c}$ \\
\hline 07 & \multicolumn{2}{|c|}{ Vacuum Purge system (Sys. 07) } & & & & \\
\hline $07-1$ & $\mathrm{H}-1-82161$ & VPS-*01-SS-1" & Vacuum Purge System & $\mathrm{SC}$ & PC-3 & Seis Cond A \\
\hline $07-1$ & $\mathrm{H}-1-82161$ & VPS-*02-SS-2" & Vacuum Purge System & SC From VPS-V-*010 to GOV- $1 * 05$ & $\begin{array}{c}\begin{array}{c}\text { PC-3 From VPS-V-*010 } \\
\text { to GOV-1*05 }\end{array} \\
\end{array}$ & Seis Cond A \\
\hline 13 & \multirow{2}{*}{\multicolumn{2}{|c|}{\begin{tabular}{|l} 
Helium systems (Sys. 13) \\
General Service Helium system (Sys. 13-1) \\
\end{tabular}}} & & & & \\
\hline $13-1$ & & & & & & \\
\hline 13-1 & $\mathrm{H}-1-82161$ & $\mathrm{He}-{ }^{*} 01-\mathrm{SS}-1 "$ & $\begin{array}{l}\text { General Service Helium Supply to PES Skid, } \\
\text { MCO Purge }\end{array}$ & $\mathrm{SC}$ from FE-1*21 to VPS-*01-SS-1" & $\begin{array}{l}\text { PC-3 from FE-1*21 to } \\
\text { VPS-*01-SS-1" }\end{array}$ & Seis Cond A \\
\hline $13-2$ & \multicolumn{3}{|c|}{ Safety class helium purge system (Sys. 13-2) } & & & \\
\hline $13-2$ & H-1-82165 & SCHe-*01-ST-1/4" & Safety Class Helium System & $\mathrm{SC}$ & $\mathrm{PC}-3$ & Seis Cond A \\
\hline $13=2$ & $1+182165$ & 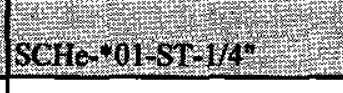 & Safey class Helinin System Dex line & 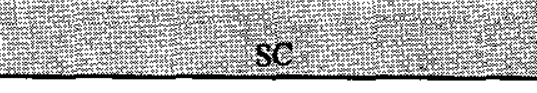 & reses & Scis eridt4 \\
\hline $13-2$ & $\mathrm{H}-1-82165$ & SCHe-*02-ST-1/4" & Safety Class Helium System & $\mathrm{SC}$ & PC-3 & Seis Cond A \\
\hline 132 & H1-82165 & 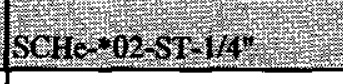 & 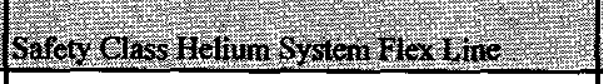 & 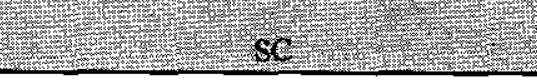 & $\operatorname{Pec}$ & $\operatorname{sers} \operatorname{cond} A$ \\
\hline $13-2$ & $\mathrm{H}-1-82165$ & SCHe-*03-ST-1/4" & Safety Class Helium System & $\mathrm{SC}$ & $\mathrm{PC}-3$ & Seis Cond $\mathrm{A}$ \\
\hline 132 & $141-82165$ & sche to3.ST14\% & Safety Class helium System Hiex Line & Vy- SC & PCs & Seis cond $x$ \\
\hline $13-2$ & $\mathrm{H}-1.82165$ & SCHe-*04-ST-1/4" & Safety Class Helium System & $\mathrm{SC}$ & $\mathrm{PC}-3$ & Seis Cond A \\
\hline 132 & 11182165 & SCHe-04:STI4: & Garejy Class I Ielium System Hex Line. & 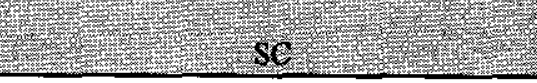 & 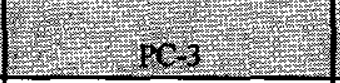 & Seis Cond A \\
\hline $13-2$ & $\mathrm{H}-1-82165$ & SCHe-*05-ST-1/4" & Safety Class Helium System & $\mathrm{SC}$ & $\mathrm{PC}-3$ & Seis Cond A \\
\hline $13-2$ & $\mathrm{H}-1-82165$ & SCHe-*06-ST-1/4" & Safety Class Helium System & $\mathrm{SC}$ & $\mathrm{PC}-3$ & Seis Cond A \\
\hline $13-2$ & $\mathrm{H}-1-82165$ & SCHe-*07-ST-1/4" & Safety Class Helium System & $\mathrm{SC}$ & $\mathrm{PC}-3$ & Seis Cond A \\
\hline $13-2$ & H-1-82165 & SCHe-*08-ST-1/4" & Safety Class Helium System & $\mathrm{SC}$ & $\mathrm{PC}-3$ & Seis Cond A \\
\hline $13-2$ & $\begin{array}{l}\mathrm{H}-1-82161 \\
\mathrm{H}-1-82165\end{array}$ & SCHe-*09-SS-1" & Safety Class Helium System & $\mathrm{SC}$ & $\mathrm{PC}-3$ & Seis Cond $\mathrm{A}$ \\
\hline $13-2$ & $\begin{array}{l}\mathrm{H}-1-82161 \\
\mathrm{H}-1-82165\end{array}$ & SCHe-*10-SS-1" & Safety Class Helium System & $\mathrm{SC}$ & PC-3 & Seis Cond $\mathrm{A}$ \\
\hline
\end{tabular}


HNF-4291, Rev, 0

Table A-2A. Cold Vacuum Drying Facility - Piping

\begin{tabular}{|c|c|c|c|c|c|c|}
\hline \multicolumn{7}{|c|}{ SC ITEMS WITH PC3 SEISMIC REQUIREMENTS AS IDENTIFIED IN SAFETY EQUIPMENT LIST } \\
\hline Sys. No. & P\&ID & Component Tag No. & Component Description/Noun Name & Safety Category Designation & $\begin{array}{c}\text { NPH and Performance } \\
\text { Category }\end{array}$ & Seismic $^{c}$ \\
\hline $13-2$ & $\begin{array}{l}\mathrm{H}-1-82161 \\
\mathrm{H}-1-82165\end{array}$ & SCHe-*11-SS-1" & Safety Class Helium System & $\mathrm{SC}$ & $\mathrm{PC}-3$ & Seis Cond A \\
\hline $13-2$ & $\begin{array}{l}\mathrm{H}-1-82161 \\
\mathrm{H}-1-82165\end{array}$ & SCHe-*12-SS-I" & Safety Class Helium System & $\mathrm{SC}$ & $\mathrm{PC}-3$ & Seis Cond $\mathrm{A}$ \\
\hline 46 & \multicolumn{3}{|c|}{ Process water conditioning system (Sys. 46) } & & & \\
\hline $46-1$ & \multicolumn{3}{|c|}{ Process water conditioning system (Sys. 46-1) } & & & \\
\hline $46-1$ & $\mathrm{H}-1-82161$ & PWC-*01-SS-1" & Process Water Conditioning at MCO & $\mathrm{SC}$ from GOV-1*03 to VPS-V-*019" & $\mathrm{PC}-3$ & Seis Cond $\mathrm{A}$ \\
\hline 47 & \multicolumn{2}{|c|}{ Cooling water system (Sys. 47) } & & & & \\
\hline $47-1$ & \multicolumn{2}{|c|}{ MCO-tempered water system (Sys. 47-1) } & & & & \\
\hline $47-1$ & $\mathrm{H}-1-82161$ & TW-*01-SS-1 1/2" & Tempered Water System & SC from Cask Conn. to SP-87 & PC-3 & Seis Cond $\mathrm{A}$ \\
\hline \multirow[t]{16}{*}{$47-1$} & $\mathrm{H}-1-82161$ & TW-*02-SS-1 1/2" & Tempered Water System & SC from Cask Conn. to SP-87 & $\mathrm{PC}-3$ & Seis Cond $\bar{A}$ \\
\hline & \multicolumn{4}{|c|}{ 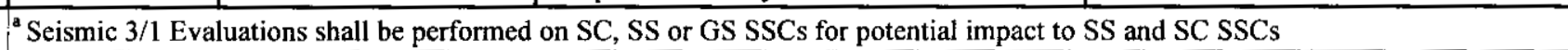 } & & \\
\hline & \multicolumn{4}{|c|}{${ }^{b}$ Sensitive LD (Leak Detection) as specified in AMSE B31.3 Section 345.8. Component must pass leak detection test. } & & \\
\hline & \multicolumn{4}{|c|}{${ }^{c}$ Seismic Qualification Conditions (Refer to Hanford document HNF-PRO-097): } & & \\
\hline & \multicolumn{6}{|c|}{ Condition A : Maintain critical function before and after Seismic event (Certification to DOE-STD-1020-94 or IEEE 344-1987 or equivalent), Confinement defined as $1 \times 10-2$ atm*ml } \\
\hline & \multicolumn{6}{|c|}{ Condition B : Maintain pressure boundary before and after Seismic event (Certification to DOE-STD-1020-94 or IEEE 344-1987 or equivalent). Component function or operation is } \\
\hline & \multicolumn{5}{|c|}{ Condition C : Maintain critical function before, during and after Seismic event (Certification to DOE-STD-1020-94 or IEEE 344-1987 or equivalent). } & \\
\hline & \multicolumn{5}{|c|}{ Condition 3/1: GS, SS or SC component cannot impact a SC component during a Seismic event (Certification to WHC-SD-GN-DGS-30006) } & \\
\hline & \multicolumn{5}{|c|}{${ }^{d}$ Environmental Conditions: Note: The CVDF is a mild environment as defined in IEEE-323 } & \\
\hline & \multicolumn{3}{|c|}{ Condition A: 60\% $\mathrm{F} @ 40 \mathrm{RH}, 75^{\circ} \mathrm{F} @ 25 \% \mathrm{RH}$} & & & \\
\hline & \multicolumn{3}{|c|}{ Condition B: $40^{\circ} \mathrm{F} @ 60 \mathrm{RH}, 115^{\circ} \mathrm{F} @ 22 \% \mathrm{RH}$} & & & \\
\hline & \multicolumn{3}{|c|}{ f Calculation Database for the CVDF project is contained in SNF-3001 } & & & \\
\hline & \multicolumn{4}{|c|}{ The base requirements of the $133 \mathrm{I}$. Code, for Safety Chss (SC), category M puping is angmented with the following: } & & \\
\hline & \multicolumn{4}{|c|}{ Thypection by an / whorized Wweleri Inspoctor } & & \\
\hline & \multicolumn{4}{|c|}{ 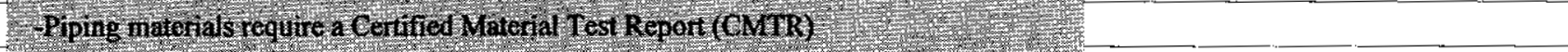 } & & \\
\hline & \multicolumn{4}{|c|}{ Tdditional $20 \%$ in process examination in addition to code required non-destuctive examination } & & \\
\hline
\end{tabular}




\begin{tabular}{|c|c|c|c|c|c|c|c|}
\hline \multicolumn{8}{|c|}{ SC ITEMS WITH PC3 SEISMIC REQUIREMENTS AS IDENTIFIED IN SAFETY EQUIPMENT LIST } \\
\hline $\begin{array}{l}\text { Sys. } \\
\text { No. }\end{array}$ & P\&ID & $\begin{array}{c}\text { Component Tag } \\
\text { No. } \\
\end{array}$ & Component Noun Name & Safety Function & $\begin{array}{c}\text { Safety } \\
\text { Category } \\
\text { Designation }\end{array}$ & $\begin{array}{c}\text { NPH and } \\
\text { Performance } \\
\text { Category }\end{array}$ & Seismic $^{c}$ \\
\hline 07 & \multicolumn{7}{|c|}{ Vacuum Purge system (Sys. 07) } \\
\hline $07-1$ & $\mathrm{H}-1-82161$ & PI-1*40 & MCO-ACC-PRESS-MON & Thermal Runaway and $\mathrm{H} 2$ Explosion prevention & $\mathrm{SC}$ & PC-3 & Seis Cond $\mathrm{A}$ \\
\hline $07-1$ & $\mathrm{H}-1-82161$ & PI-1*41 & MCO-ACC-PRESS-MON & Thermal Runaway and H2 Explosion prevention & $\mathrm{SC}$ & $\mathrm{PC}-3$ & Seis Cond $\mathrm{A}$ \\
\hline $07-1$ & $\mathrm{H}-1-82161$ & PT-1*08 ${ }^{\mathrm{h}}$ & MCO-DISCH-PRESS-XMTTR-TRN-A & $\begin{array}{l}\text { Thermal Runaway and H2 Explosion prevention; Pressure boundary } \\
\text { is seismic, signal is non-seismic }\end{array}$ & $\mathrm{SC}$ & PC-3 & Seis Cond B \\
\hline $07-1$ & $\mathrm{H}-1.82161$ & PT $-1 * 10^{\mathrm{h}}$ & MCO-DISCH-PRESS-XMTTR-TRN-B & $\begin{array}{l}\text { Thermal Runaway and } \mathrm{H} 2 \text { Explosion prevention; Pressure boundary } \\
\text { is seismic, signal is non-seismic }\end{array}$ & $\mathrm{SC}$ & $\mathrm{PC}-3$ & Seis Cond B \\
\hline $07-1$ & $\mathrm{H}-1-82161$ & PT- $1 * 36$ & MCO-DISCH-PRESS-XMTTR-TRN-A & $\begin{array}{l}\text { Thermal Runaway and H2 Explosion prevention; Pressure boundary } \\
\text { is seismic, signal is non-seismic }\end{array}$ & $\mathrm{SC}$ & $\mathrm{PC}-3$ & Seis Cond B \\
\hline $13-1$ & \multicolumn{7}{|c|}{ General Service Helium system (Sys. 13-1) } \\
\hline $13-1$ & $\mathrm{H}-1.82161$ & PT-1*34 & He-SUPPLY-MCO-PRESS & $\begin{array}{l}\text { Thermal Runaway and H2 Explosion prevention; pressure boundary } \\
\text { only }\end{array}$ & $\mathrm{SC}$ & $\mathrm{PC}-3$ & Seis Cond B \\
\hline $13-1$ & $\mathrm{H}-1-82161$ & $\mathrm{PT}-1 * 35$ & He-SUPPLY-MCO-PRESS & $\begin{array}{l}\text { Thermal Runaway and H2 Explosion prevention; pressure boundary } \\
\text { only }\end{array}$ & $\mathrm{SC}$ & PC-3 & Seis Cond B \\
\hline $13-2$ & \multicolumn{7}{|c|}{ Safety class helium purge system (Sys. 13-2) } \\
\hline $13-2$ & $\mathrm{H}-1-82165$ & $\mathrm{FI}-5^{*} 10$ & SCHe Flow Indication to $\mathrm{MCO}$ & $\begin{array}{l}\text { Thermal Runaway and H2 Explosion prevention; pressure boundary } \\
\text { only }\end{array}$ & $\mathrm{SC}$ & PC-3 & Seis Cond B \\
\hline $13-2$ & $\mathrm{H}-1-82165$ & FI-5*29 & SCHe Flow Indication to $\mathrm{MCO}$ & $\begin{array}{l}\text { Thermal Runaway and } \mathrm{H} 2 \text { Explosion prevention; pressure boundary } \\
\text { only }\end{array}$ & $\mathrm{SC}$ & PC-3 & Seis Cond B \\
\hline $13-2$ & $\mathrm{H}-1-82165$ & $\mathrm{FI}-5^{*} 49$ & SCHe Flow Indication to $\mathrm{MCO}$ & $\begin{array}{l}\text { Thermal Runaway and } \mathrm{H} 2 \text { Explosion prevention; pressure boundary } \\
\text { only }\end{array}$ & $\mathrm{SC}$ & $\mathrm{PC}-3$ & Seis Cond B \\
\hline $13-2$ & $\mathrm{H}-1-82165$ & FI $-5 * 69$ & SCHe Flow Indication to $\mathrm{MCO}$ & $\begin{array}{l}\text { Thermal Runaway and } \mathrm{H} 2 \text { Explosion prevention; pressure boundary } \\
\text { only }\end{array}$ & $\mathrm{SC}$ & PC-3 & Seis Cond B \\
\hline $13-2$ & $\mathrm{H}-1.82165$ & FI-5*76 & SCHe Flow Indication to $\mathrm{MCO}$ & $\begin{array}{l}\text { Thermal Runaway and H2 Explosion prevention; pressure boundary } \\
\text { only }\end{array}$ & $\mathrm{SC}$ & PC-3 & Seis Cond B \\
\hline $13-2$ & $\mathrm{H}-1-82165$ & FI-5*77 & SCHe Flow Indication to $\mathrm{MCO}$ & $\begin{array}{l}\text { Thermal Runaway and } \mathrm{H} 2 \text { Explosion prevention; pressure boundary } \\
\text { only }\end{array}$ & $\mathrm{SC}$ & $\mathrm{PC}-3$ & Seis Cond B \\
\hline $13-2$ & $\mathrm{H}-1-82165$ & Fl-5*78 & SCHe Flow Indication to $\mathrm{MCO}$ & $\begin{array}{l}\text { Thermal Runaway and H2 Explosion prevention; pressure boundary } \\
\text { only }\end{array}$ & $\mathrm{SC}$ & $\mathrm{PC}-3$ & Seis Cond B \\
\hline-8 & $\mathrm{H}-1-82165$ & FI-5*79 & SCHe Flow Indication to $\mathrm{MCO}$ & $\begin{array}{l}\text { Thermal Runaway and H2 Explosion prevention; pressure boundary } \\
\text { only }\end{array}$ & SC & PC-3 & Seis Cond B \\
\hline $13-2$ & $\mathrm{H}-1-82165$ & PI-5*02 & \#REF! & $\begin{array}{l}\text { Thermal Runaway and } \mathrm{H} 2 \text { Explosion prevention, accident } \\
\text { monitoring }\end{array}$ & $\mathrm{SC}$ & PC-3 & Seis Cond A \\
\hline $13-2$ & H-1-82165 & $\mathrm{PI}-5^{*} 07$ & 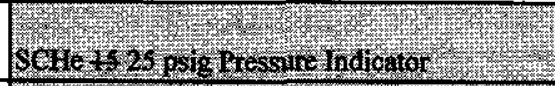 & $\begin{array}{l}\text { Thermal Runaway and H2 Explosion prevention; pressure boundary } \\
\text { only }\end{array}$ & $\mathrm{SC}$ & $\mathrm{PC}-3$ & Seis Cond B \\
\hline $13-2$ & $\mathrm{H}-1-82165$ & PI-5*09 & 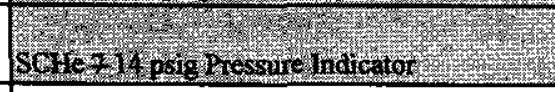 & $\begin{array}{l}\text { Thermal Runaway and H2 Explosion prevention; pressure boundary } \\
\text { only }\end{array}$ & $\mathrm{SC}$ & PC-3 & Seis Cond $\mathrm{B}$ \\
\hline $13-2$ & $\mathrm{H}-1-82165$ & $\mathrm{PI}-5 * 21$ & \#REF! & $\begin{array}{l}\text { Thermal Runaway and } \mathrm{H} 2 \text { Explosion prevention, accident } \\
\text { monitoring }\end{array}$ & $\mathrm{SC}$ & PC-3 & Seis Cond A \\
\hline $13-2$ & $\mathrm{H}-1-82165$ & PI-5*26 & Sche 425 psig pressure indicator & $\begin{array}{l}\text { Thermal Runaway and } \mathrm{H} 2 \text { Explosion prevention; pressure boundary } \\
\text { only }\end{array}$ & $\mathrm{SC}$ & PC-3 & Seis Cond B \\
\hline
\end{tabular}




\begin{tabular}{|c|c|c|c|c|c|c|c|}
\hline \multicolumn{8}{|c|}{ SC ITEMS WITH PC3 SEISMIC REQUIREMENTS AS IDENTIFIED IN SAFETY EQUIPMENT LIST } \\
\hline $\begin{array}{l}\text { Sys. } \\
\text { No. }\end{array}$ & P\&ID & $\begin{array}{l}\text { Component Tag } \\
\text { No. }\end{array}$ & Component Noun Name & Safety Function & $\begin{array}{c}\text { Safety } \\
\text { Category } \\
\text { Designation }\end{array}$ & $\begin{array}{c}\text { NPH and } \\
\text { Performance } \\
\text { Category }\end{array}$ & Seismic $^{\mathrm{c}}$ \\
\hline $13-2$ & H-1-82165 & PI.5*28 & SCHe 714 psig Pressure ladicator & $\begin{array}{l}\text { Thermal Runaway and } \mathrm{H} 2 \text { Explosion prevention; pressure boundary } \\
\text { only }\end{array}$ & $\mathrm{sC}$ & PC-3 & Seis Cond B \\
\hline $13-2$ & $\mathrm{H}-1-82165$ & PI $-5 * 41$ & \#REF! & $\begin{array}{l}\text { Thermal Runaway and H2 Explosion prevention, accident } \\
\text { monitoring }\end{array}$ & $\mathrm{SC}$ & $\mathrm{PC}-3$ & Seis Cond A \\
\hline $13-2$ & H-1-82165 & PI-5*46 & SCHe 1525 psig Pressure lindicator. & $\begin{array}{l}\text { Thermal Runaway and } \mathrm{H} 2 \text { Explosion prevention; pressure boundary } \\
\text { only }\end{array}$ & $\mathrm{SC}$ & PC-3 & Seis Cond B \\
\hline $13-2$ & H-1-82165 & PI-5*48 & \#REF! & $\begin{array}{l}\text { Thermal Runaway and H2 Explosion prevention; pressure boundary } \\
\text { only }\end{array}$ & $\mathrm{SC}$ & PC-3 & Seis Cond B \\
\hline $13-2$ & H-1-82165 & PI-5*61 & \#REF! & $\begin{array}{l}\text { Thermal Runaway and } \mathrm{H} 2 \text { Explosion prevention, accident } \\
\text { monitoring }\end{array}$ & $\mathrm{SC}$ & PC-3 & Seis Cond A \\
\hline $13-2$ & $\mathrm{H}-1-82165$ & PI-5*66 & Sche 1525 psig dressure Indicator & $\begin{array}{l}\text { Thermal Runaway and } \mathrm{H} 2 \text { Explosion prevention; pressure boundary } \\
\text { only }\end{array}$ & $\mathrm{SC}$ & PC-3 & Seis Cond B \\
\hline $13-2$ & H-1-82165 & PI-5*68 & \#REF! & $\begin{array}{l}\text { Thermal Runaway and H2 Explosion prevention; pressure boundary } \\
\text { only }\end{array}$ & $\mathrm{SC}$ & PC-3 & Seis Cond B \\
\hline $13-2$ & H-1-82165 & PSL-5*03 & \#REF! & $\begin{array}{l}\text { Thermal Runaway and } \mathrm{H} 2 \text { Explosion prevention; pressure boundary } \\
\text { only }\end{array}$ & SC & $\mathrm{PC}-3$ & Seis Cond $\mathrm{B}$ \\
\hline $13-2$ & $\mathrm{H}-1-82165$ & PSL-5*06 & sche 15 25 psig Pressire Switch Low & $\begin{array}{l}\text { Thermal Runaway and } \mathrm{H} 2 \text { Explosion prevention; pressure boundary } \\
\text { only }\end{array}$ & $\mathrm{SC}$ & PC-3 & Seis Cond B \\
\hline $13-2$ & H-1-82165 & PSL-5*22 & \#REF! & $\begin{array}{l}\text { Thermal Runaway and } \mathrm{H} 2 \text { Explosion prevention; pressure boundary } \\
\text { only }\end{array}$ & $\mathrm{SC}$ & $\mathrm{PC}-3$ & Seis Cond B \\
\hline $13-2$ & $\mathrm{H}-1-82165$ & PSL-5*25 & solle 1525 psig Pressure Switch Low & $\begin{array}{l}\text { Thermal Runaway and H2 Explosion prevention; pressure boundary } \\
\text { only }\end{array}$ & $\mathrm{SC}$ & PC-3 & Seis Cond B \\
\hline $13-2$ & H-1-82165 & PSL-5*42 & \#REF! & $\begin{array}{l}\text { Thermal Runaway and } \mathrm{H} 2 \text { Explosion prevention; pressure boundary } \\
\text { only }\end{array}$ & SC & PC-3 & Seis Cond B \\
\hline $13-2$ & $\mathrm{H}-1-82165$ & PSL-5*45 & Sefle 15 25 psig Pressure Switch Low & $\begin{array}{l}\text { Thermal Runaway and H2 Explosion prevention; pressure boundary } \\
\text { only }\end{array}$ & $\mathrm{SC}$ & PC-3 & Seis Cond B \\
\hline $13-2$ & H-1-82165 & PSL-5*62 & $50=1$ & $\begin{array}{l}\text { Thermal Runaway and } \mathrm{H} 2 \text { Explosion prevention; pressure boundary } \\
\text { only }\end{array}$ & $\mathrm{SC}$ & PC-3 & Seis Cond B \\
\hline $13-2$ & H-1-82165 & PSL-5*65 & SCfie is 25 psig Pressure Swich Low & $\begin{array}{l}\text { Thermal Runaway and } \mathrm{H} 2 \text { Explosion prevention; pressure boundary } \\
\text { only }\end{array}$ & $\mathrm{SC}$ & PC-3 & Seis Cond B \\
\hline $13-2$ & H-1-82165 & PT $-5 * 01$ & \#REF! & $\begin{array}{l}\text { Thermal Runaway and H2 Explosion prevention; pressure boundary } \\
\text { only }\end{array}$ & $\mathrm{SC}$ & PC-3 & Seis Cond B \\
\hline $13-2$ & H-1-82165 & PT $-5 * 20$ & \#REF! & $\begin{array}{l}\text { Thermal Runaway and } \mathrm{H} 2 \text { Explosion prevention; pressure boundary } \\
\text { only }\end{array}$ & sc & $\mathrm{PC}-3$ & Seis Cond B \\
\hline $13-2$ & H-1-82165 & PT $-5 * 40$ & \#REF! & $\begin{array}{l}\text { Thermal Runaway and H2 Explosion prevention; pressure boundary } \\
\text { only }\end{array}$ & $\mathrm{sc}$ & PC-3 & Seis Cond B \\
\hline $13-2$ & $\mathrm{H}-1-82165$ & PT $-5 * 60$ & \#REF! & $\begin{array}{l}\text { Thermal Runaway and H2 Explosion prevention; pressure boundary } \\
\text { only }\end{array}$ & SC & PC-3 & Seis Cond B \\
\hline 47 & Cooling wat & ystem (Sys. 47) & & & & & \\
\hline $47-1$ & MCO-tempe & water system (Sy) & $.47-1)$ & & & & \\
\hline
\end{tabular}




\begin{tabular}{|c|c|c|c|c|c|c|c|}
\hline \multicolumn{8}{|c|}{ SC ITEMS WITH PC3 SEISMIC REQUIREMENTS AS IDENTIFIED IN SAFETY EQUIPMENT LIST } \\
\hline $\begin{array}{l}\text { Sys. } \\
\text { No. }\end{array}$ & P\&ID & $\begin{array}{l}\text { Component Tag } \\
\text { No. }\end{array}$ & Component Noun Name & Safety Function & $\begin{array}{c}\text { Safety } \\
\text { Category } \\
\text { Designation } \\
\end{array}$ & $\begin{array}{l}\text { NPH and } \\
\text { Performance } \\
\text { Category }\end{array}$ & Seismic $^{\mathrm{c}}$ \\
\hline $47-1$ & $\mathrm{H}-1-82161$ & LG-1*24 & TW-ANNULUS-LVL-GAGE-OUT & $\begin{array}{l}\text { Accident Monitoring of Cask Annulus water level for Runaway } \\
\text { Reaction Prevention (part of level alarm function for LSH } 1 * 24\end{array}$ & $\mathrm{SC}$ & PC-3 & Seis Cond $\mathrm{A}$ \\
\hline $47-1$ & $\mathrm{H}-1-82161$ & LG-1*25 & TW-ANNULUS-LVL-GAGE-IN & $\begin{array}{l}\text { Accident Monitoring of Cask Annulus water level for Runaway } \\
\text { Reaction Prevention (part of level alarm function for LSH } 1 * 25\end{array}$ & $\mathrm{SC}$ & $\mathrm{PC}-3$ & Seis Cond A \\
\hline $93-2$ & \multicolumn{7}{|c|}{ Safety class $1 \&$ C system (Sys. 93-2) } \\
\hline $93-2$ & TBD & 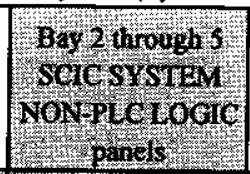 & CP- $211,310,411,510$ & H2 Explosion prevention; Runaway Reaction Prevention & $\mathrm{SC}$ & PC-3 & Seis Cond C \\
\hline $93-2$ & LBD & 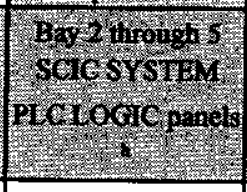 & $\operatorname{cr} 210,311,410,511$ & WE Explosion prevention; Runaway Reaction Prevention & $\mathrm{se}$ & & Seis Cond C \\
\hline $93-2$ & TBD & $\begin{array}{c}\text { SC Wiring, conduit } \\
\text { and supports }\end{array}$ & NA & H2 Explosion prevention; Runaway Reaction Prevention & $\mathrm{SC}$ & PC-3 & Seis Cond C \\
\hline $93-2$ & TBD & ATR-S436 5235 & Cr 220 Seisnic Recorder Bay 2 . & $\begin{array}{l}\text { Seismic trip for H2 Explosion prevention; Runaway Reaction } \\
\text { Prevention }\end{array}$ & Sc & PC-3 & Seis Cond $\mathrm{C}$ \\
\hline $93-2$ & TBD & ATR S335 5336 & Ge320 Seismic Recorder Bay 3 . S & $\begin{array}{l}\begin{array}{l}\text { Seismic trip for H2 Explosion prevention; Runaway Reaction } \\
\text { Prevention }\end{array} \\
\end{array}$ & $\mathrm{SC}$ & PC-3 & Seis Cond C \\
\hline $93-2$ & TBD & itw 3527.547 & EP 480 -Seismic Recorder Bay 4 & $\begin{array}{l}\text { Seismic trip for H2 Explosion prevention; Runaway Reaction } \\
\text { Prevention }\end{array}$ & $\mathrm{SC}$ & PC-3 & Seis Cond $\mathrm{C}$ \\
\hline $93-2$ & TBD & $\operatorname{cor} 120 \times 1 \times-528$ & EP120-Seismic Anctioneerng Panel Train $\mathrm{A}$ & $\begin{array}{l}\text { Seismic trip for } \mathrm{H} 2 \text { Explosion prevention; Runaway Reaction } \\
\text { Prevention }\end{array}$ & SC & $\mathrm{PC}-3$ & Seis Cond C \\
\hline 93-2 & TBD & $\operatorname{cr}-121 \mathrm{Ax}=5329$ & 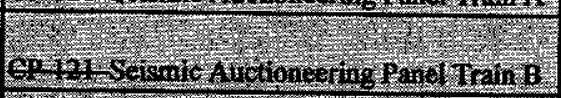 & $\begin{array}{l}\text { Seismic trip for } \mathrm{H} 2 \text { Explosion prevention; Runaway Reaction } \\
\text { Prevention }\end{array}$ & $\mathrm{SC}$ & PC-3 & Seis Cond $\mathrm{C}$ \\
\hline 932 & $\mathrm{gaD}$ & $\mathrm{or}_{122}$ & Seismio Butivi ranal rmin $\mathrm{A}$. & 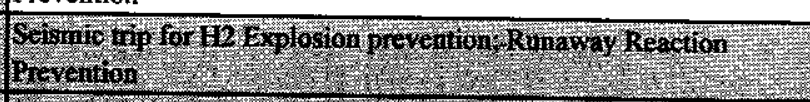 & SC: & $\mathrm{PC}-3$ & Sen Cond C \\
\hline $93-2$ & $\tan 2$. & 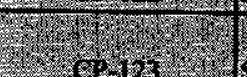 & Soismic Buffer Panth Trin B & 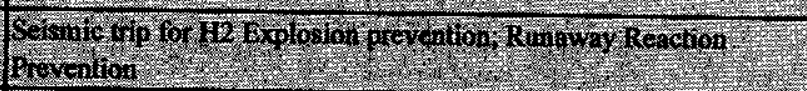 & & $\mathrm{rC}_{3} 3$ & Scis Cond C \\
\hline 932 & IBD & 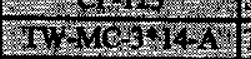 & 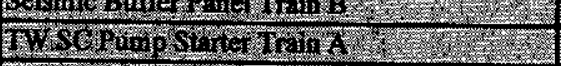 & 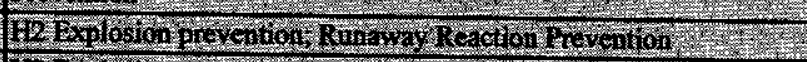 & $\operatorname{se}$ & PC-3 & Seis CondC \\
\hline 932 & Tid & 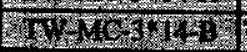 & 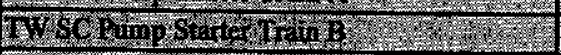 & 62 Explosion prevention, Ronaviy Regetion Provention & SC. & DSC-3 & Sciscond C \\
\hline 93.2. & 180. & TWMC-3HTA & 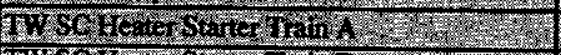 & H2 Explostion provention, Ruhaway Resction Prevention & se. & Pe-3 & Sers coud Cl \\
\hline 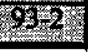 & IDOW & 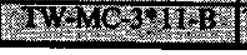 & IN SC Reater Strier Train B & 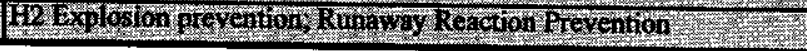 & & PC-3 & Seisconde \\
\hline & ${ }^{\mathrm{a}}$ Seismic 3/1 E & valuations shall be pe & eerformed on SC, SS or GS SSCs for potential in & & & & \\
\hline & ${ }^{\mathrm{c}}$ Seismic Qual & ification Conditions ( & (Refer to Hanford document HNF-PRO-097) : & & & & \\
\hline & & & & & & $0-2 \mathrm{~atm}^{*}$ & or less. \\
\hline & Condition B : & Maintain pressure & 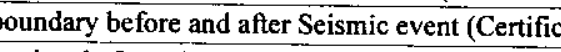 & & & & \\
\hline & Condition C: & Maintain critical $\mathrm{f}$ & & 4 or IEEE $344-1987$ or equiv & & & \\
\hline & & 1: GS, SS or SC comp & aponent cannot impact a SC compone & smic event (certification to wh & & & \\
\hline
\end{tabular}




\begin{tabular}{|c|c|c|c|c|c|c|c|c|c|c|}
\hline 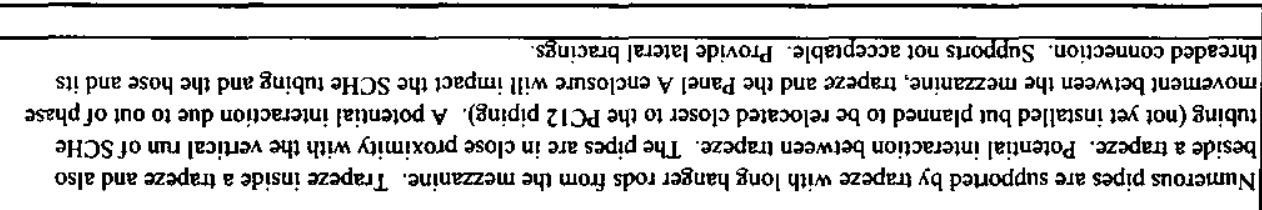 & 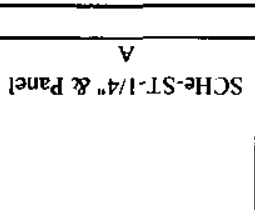 & & $\mathrm{JZJdEI}^{\prime} \mathrm{CH}$ & $1 / \mathcal{E}$ & $.1-\mathrm{dd}$ & S5 & spuddns כold & 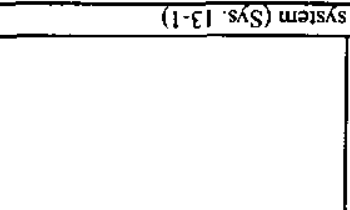 & 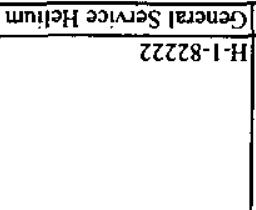 & 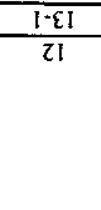 \\
\hline & & & & & & & 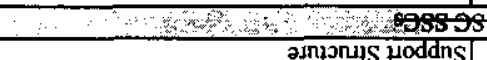 & 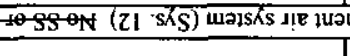 & isul pue & 21 \\
\hline 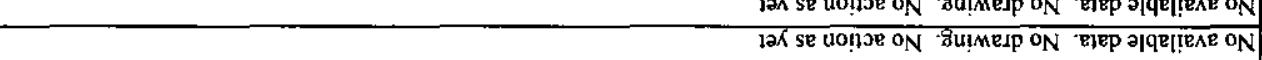 & & & & $\frac{1 / / / 6}{1 / \mathcal{E}}$ & 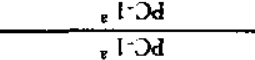 & $\frac{25}{25}$ & 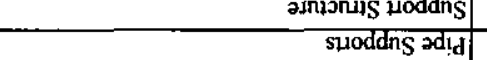 & - & 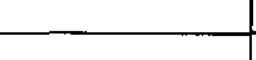 & $\begin{array}{lll}\varepsilon<-20 \\
\varepsilon<-20\end{array}$ \\
\hline 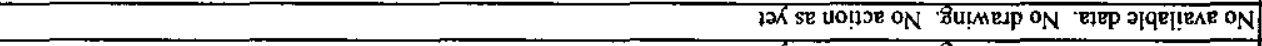 & & & & $1 / \varepsilon$ & $8-3 \mathrm{~d}$ & S5 & $\operatorname{sduind} \cdot \mathfrak{P}_{\Lambda} \overline{\mathrm{q} T \mathrm{TSN}}$ & & & $\varepsilon-20$ \\
\hline 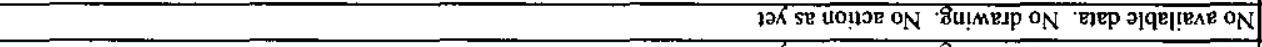 & & & & $1 / \varepsilon$ & ilod & SD & 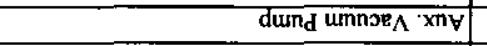 & & & $\varepsilon=20$ \\
\hline 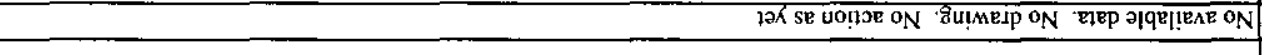 & & & & $\mathrm{t} / \mathrm{s}$ & il-Dd & s5 & 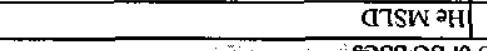 & & & $\varepsilon=20$ \\
\hline 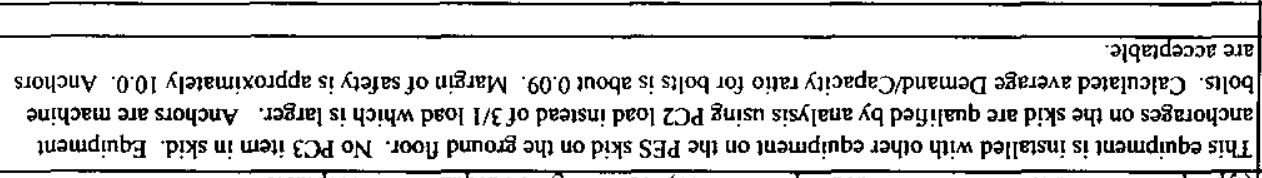 & 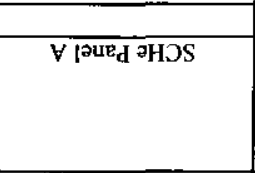 & VZI-S-88zz & p.yS SYd & $1 / \varepsilon$ & $e^{1-\partial d}$ & so & 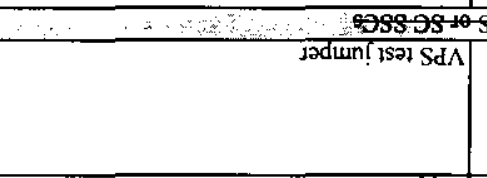 & 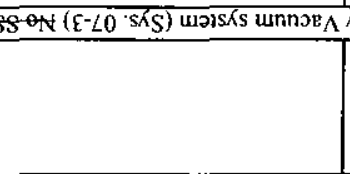 & 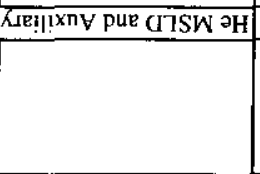 & $\frac{\varepsilon-20}{1-\angle 0}$ \\
\hline 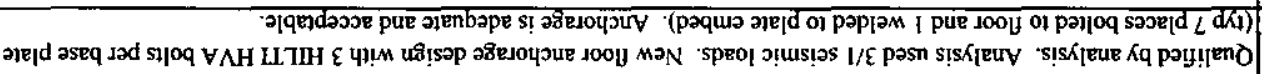 & 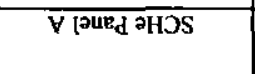 & $9.09 \mathrm{IZ9ZIIWN}$ & 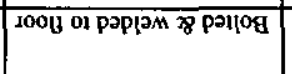 & t/డ & $.2-3 d$ & So & Sad '2minonus roddns & & $19178 \cdot 1 \cdot \mathrm{H}$ & $1-20$ \\
\hline & 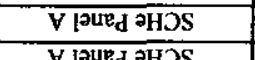 & 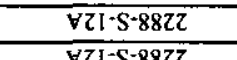 & 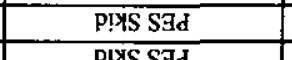 & $\frac{1 / \varepsilon}{1 / \varepsilon}$ & 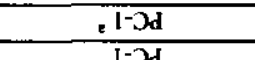 & $\frac{52}{S 0}$ & 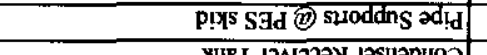 & & 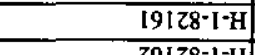 & $1-\angle 0$ \\
\hline 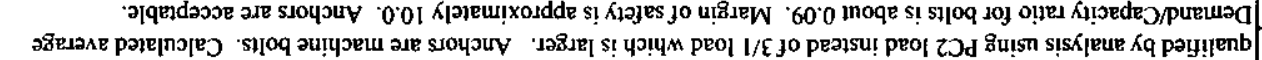 & 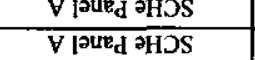 & $\frac{\nabla Z 1-588 z 2}{\forall z-588 z 2}$ & $\frac{\text { PI!YY Sad }}{\text { PI:YS Sad }}$ & $\frac{1 / / \varepsilon}{1 / \varepsilon}$ & $\frac{11-09}{1-09}$ & $\frac{\text { So }}{S 2}$ & 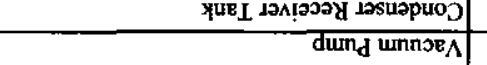 & 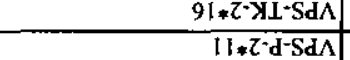 & $z 92[28-1-1-1]$ & $\begin{array}{l}1-\angle 0 \\
1-20\end{array}$ \\
\hline 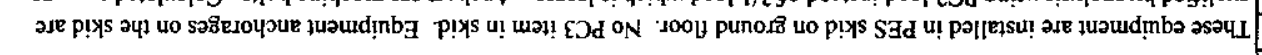 & 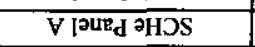 & VZI-S-S8zz & PIYS SId & $1 / \mathcal{E}$ & it-Jd & so & נasuapuog & $\varepsilon 1_{* 2}-\mathrm{aNOJ} \cdot \mathrm{Sd} \Lambda$ & $29178-1-\mathrm{H} \mid$ & $\frac{1-20}{1-L 0}$ \\
\hline & 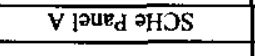 & VZI-S-88zZ & PIYS Sidd & $1 / \varepsilon$ & 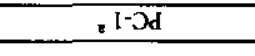 & S5 & 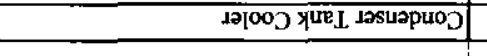 & 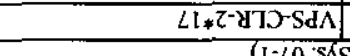 & 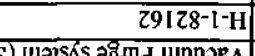 & $\overline{T-L 0}$ \\
\hline 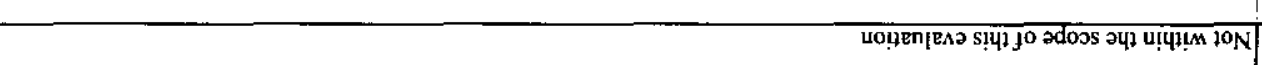 & & & & $1 / \varepsilon$ & $z-O d$ & so & 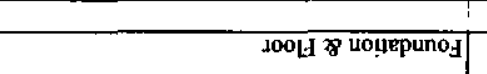 & 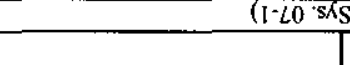 & 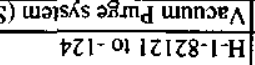 & $\frac{I \angle 0}{1-90}$ \\
\hline 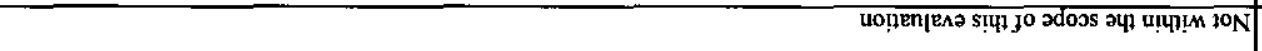 & & & & $\overline{t / \varepsilon}$ & $z-\partial d$ & S5 & 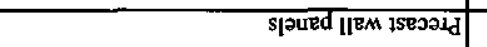 & & DZI- ol IZIZZ-i-H & 590 \\
\hline 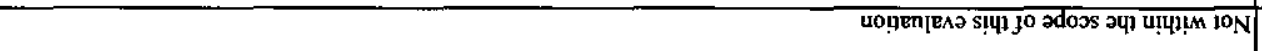 & & & & $1 / \varepsilon$ & $\overline{z-\partial d}$ & SD & emanis joov & & $01 I^{\circ} 8 z I z 8-1 \cdot H$ & $\square=90$ \\
\hline 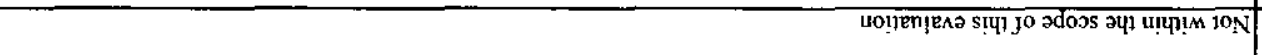 & & & & $T / \varepsilon$ & 7-Od & SD & 8ụtuey [emmonis & & oEI ' $6 \mathrm{ZIZZ-1-H}$ & 590 \\
\hline 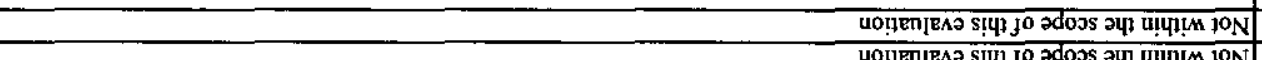 & & & & $1 / \varepsilon$ & $z=\mathrm{d}$ & 59 & 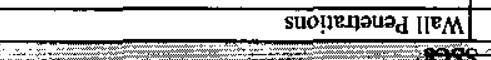 & 2mannis & 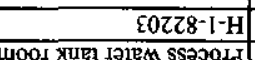 & $\frac{790}{500}$ \\
\hline 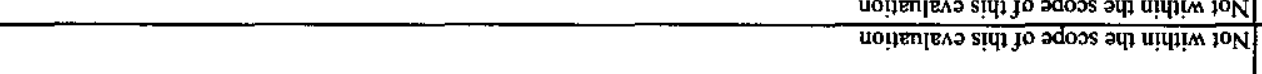 & & & $=2$ & $1 / \varepsilon$ & $\overline{z \cdot O d}$ & S5 & ssooly pue uoliepunos & & 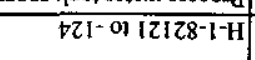 & $\frac{x \rightarrow 0}{\varepsilon-90}$ \\
\hline 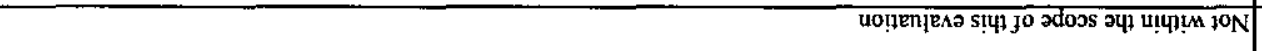 & & & & $1 / \varepsilon$ & $\tau-\mathrm{Od}$ & SD & SIIPM & & gZI'SZIZ8-I-H & $\varepsilon=90$ \\
\hline 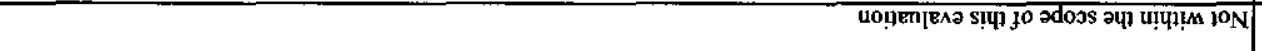 & & & & $1 / \varepsilon$ & $2-\partial d$ & SD & 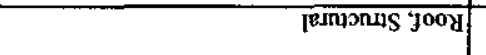 & & $011 \times 8 z 178-[-H$ & $\varepsilon=90$ \\
\hline 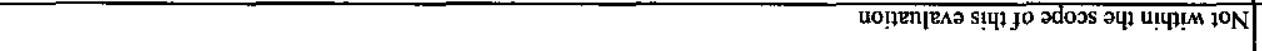 & & & & $1 / \varepsilon$ & $z-\mathrm{Od}$ & So & 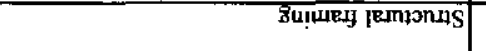 & & OEI '6ZIZ8-I-H & $\varepsilon=90$ \\
\hline 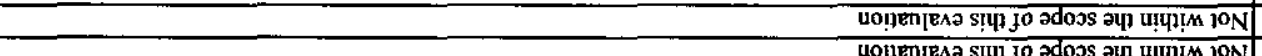 & & & 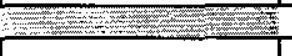 & & & & 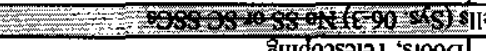 & 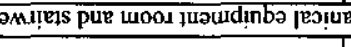 & 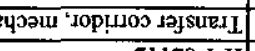 & $\varepsilon-90$ \\
\hline 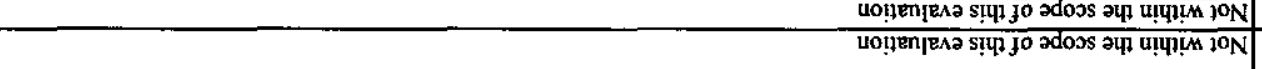 & & & & $\frac{1 / \varepsilon}{1 / \delta}$ & 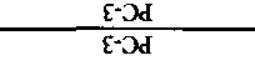 & $\frac{S 9}{S 9}$ & 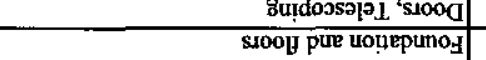 & & 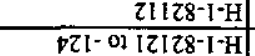 & $\frac{z-90}{\tau-90}$ \\
\hline 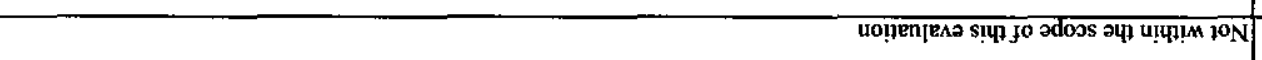 & & & & $1 / \mathcal{E}$ & $\varepsilon=\partial d$ & So & 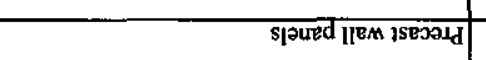 & & 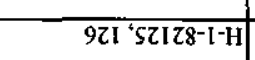 & $z-90$ \\
\hline 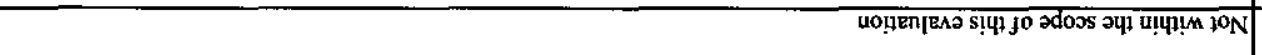 & & & & $\mathrm{T/ \varepsilon}$ & $\varepsilon=O d$ & So & Jermonns joov & & 011 '8ZIZ8-I-H & $\tau-90$ \\
\hline 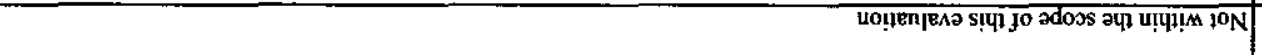 & & & & $t / \varepsilon$ & $\varepsilon=\mathrm{Od}$ & so & Sựuey [emmonus & & 0 0हा' $62128 \cdot-\mathrm{H}$ & $z-90$ \\
\hline U: & & & 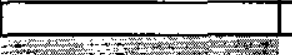 & $1 / \varepsilon$ & $\varepsilon=2 d$ & S5 & 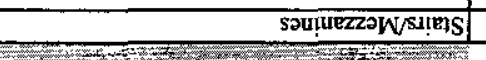 & (2) & 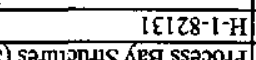 & $z-90$ \\
\hline 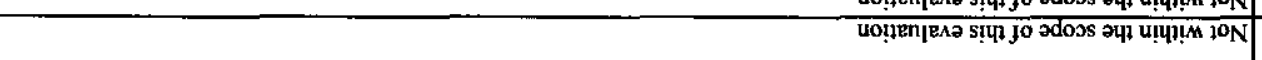 & & & & $\overline{l / \varepsilon}$ & $.10 d$ & SD & 8uguexy femonus & ס & 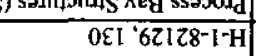 & $\frac{c-90}{1-90}$ \\
\hline 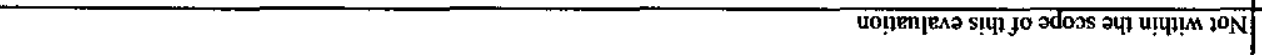 & & & & $\overline{1 / \varepsilon}$ & $.1 \cdot 2 d$ & So & 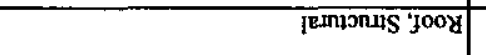 & & 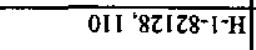 & $1-90$ \\
\hline 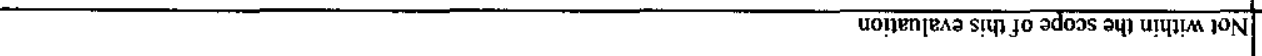 & & & & $1 / \varepsilon$ & .10d & So & $S_{\| \mathbb{M}}$ & & 9zI' 'szlz8-1-H & $1-90$ \\
\hline 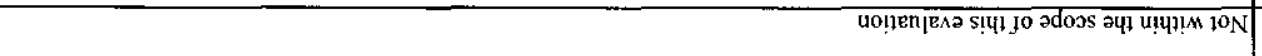 & & & & $1 / \varepsilon$ & $\operatorname{Ri}_{1-9}$ & SO & silooly pue uog!epunof & & 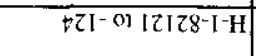 & $1-90$ \\
\hline รцгошюว & 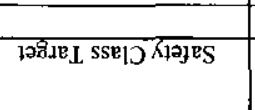 & 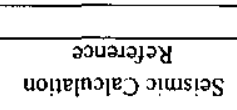 & 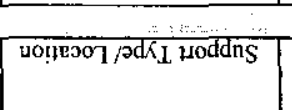 & 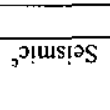 & 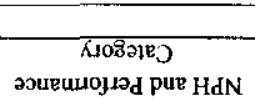 & 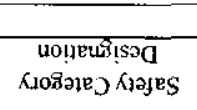 & 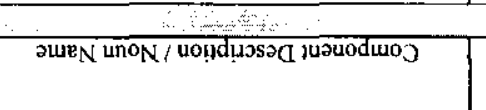 & 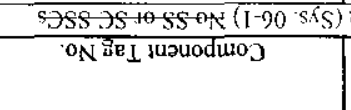 & 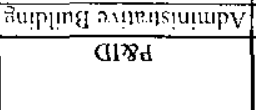 & $\frac{1-90}{0^{N} \cdot 26 \mathrm{~S}}$ \\
\hline
\end{tabular}




\begin{tabular}{|c|c|c|c|c|c|c|c|c|c|c|}
\hline \multicolumn{11}{|c|}{ SEISMIC 3/1 ITEMS IDENTIFIED IN MASTER EQUIPMENT LIST } \\
\hline Sys. No. & P\&ID & Component Tag No. & Component Description / Noun Name & $\begin{array}{c}\text { Safery Category } \\
\text { Designation } \\
\end{array}$ & $\begin{array}{c}\text { NPH and Performance } \\
\text { Category } \\
\end{array}$ & Seismic $^{c}$ & Support Type/ Location & $\begin{array}{c}\text { Seismic Calculation } \\
\text { Reference }\end{array}$ & \begin{tabular}{|l|l|} 
Safety Class Target \\
\end{tabular} & Conmments \\
\hline$\frac{13-1}{14}$ & $\frac{\mathrm{H}-1-82222}{\text { Cranes and hoists (Sys.1 }}$ & 14) No SS ar SCSSES & Pipe Supports - GS & $\underline{G S}$ & $P C \cdot 1^{2}$ & $3 / 1$ & H7, Trapeze & & SCIle-ST-1/1/4 \& Panel & 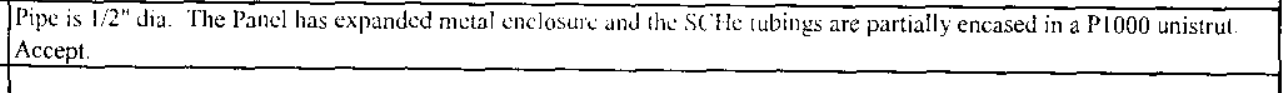 \\
\hline$\frac{14}{19}$ & \begin{tabular}{|l}
$\mathrm{H} \cdot 1-\mathrm{-} 21232$ \\
Condensate collection sy
\end{tabular} & | & Process Bay Overhead Crane & GS & $\mathrm{PC}-1^{2}$ & $3 / 1$ & 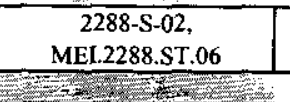 & & Process Hood & Designed for PC3 seismic loads. Accept. \\
\hline$\frac{19}{20-1}$ & $\frac{\mathrm{H}-1-82223}{\text { Electrical power distribu }}$ & ution system (Sys. 20-1) & Condensate collection tanks & GS & $\mathrm{PC}-1^{2}$ & $3 / 1$ & H-1.82225, detain 1 & HNF -4291 & \begin{tabular}{|c|c|c|c|} 
SCHe-ST-1/4" \& Panel \\
B
\end{tabular} & $\begin{array}{l}\text { Calculation attached. Support ot acceptable. Provide lateral bracings of fall protection cable to prevent falling on SCHe } \\
\text { Panel B located below the tank. }\end{array}$ \\
\hline$\frac{20 \cdot 1}{20 \cdot 2}$ & Lighting Exxemal/ntren & nal[Exit/Emergency]_(Sys. 20-2) & Distribution Panels(@ Process Bay) & GS & $\mathrm{PC}-1^{2}$ & $3 / 1$ & $\mathrm{DCN} \mathrm{W-441-193, \textrm {pg } 5 / 2 6}$ & & SCIC Control Panel & $\begin{array}{l}\text { Instalataion of distribution panels in one of the process bays is almosst complete. Evaluated adequacy by field walkdown. } \\
\text { Anchorage is adequate. }\end{array}$ \\
\hline$\frac{20-2}{24}$ & $\begin{array}{l}\text { H-1-822241, } 242,-246,- \\
247,-248, \\
\text { Fire protection system (S) }\end{array}$ & Sys. 24) & Intemal Lighing(@ Process Bay) & GS & ${\mathrm{PC}-\mathrm{I}^{2}}^{2}$ & 3/1 & & & $\begin{array}{c}\mathrm{scic} \text { CP, } 1 / 4 \text { " sCHe \& } \\
\text { Proc Hood }\end{array}$ & Evaluated by walkdown. Supports not adequate. Provide fall protection cable for suspended light fixtures. \\
\hline$\frac{24}{25}$ & \begin{tabular}{|l} 
H.1-1.82237 H.1-82240 \\
Deionized water system
\end{tabular} & 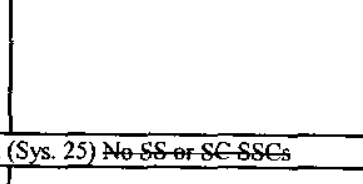 & Pipe Supports & GS & $\mathrm{PC}-2^{2}$ & $3 / 1$ & NFPA-13 & & $\begin{array}{c}\text { SCIC CP, } 1 / 4 \text { "sCHe \& } \\
\text { Proc Hood } \\
\end{array}$ & 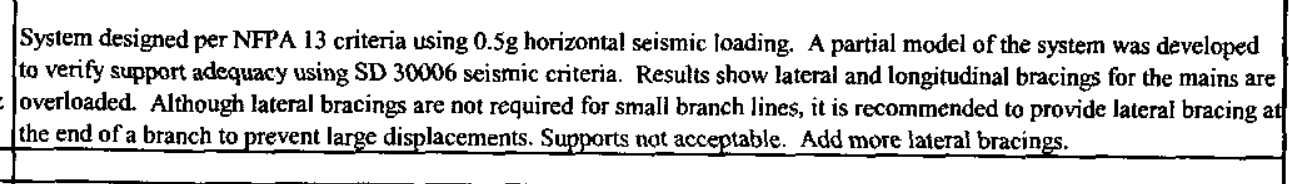 \\
\hline$\frac{25}{30-2}$ & Hi-1-82222 & is Bay Supply/Recirc.](Sys. 30-2)! & 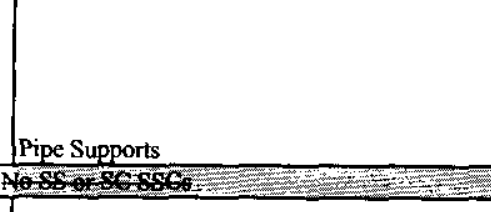 & GS & $P C-1^{2}$ & $3 / 1$ & H7, Trapeze & & SCHe-ST-1/4" \& Panel & 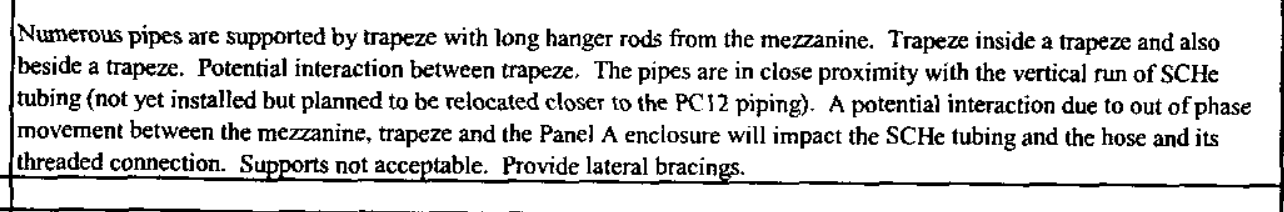 \\
\hline$-30-2$ & H-1-82204 & HVAC-CCL- $8 * 03$ & Cooling Coil & Gs & $\mathrm{PC}-1^{2}$ & 3/1 & Frame & MEL.2621.EQ.04 & \multirow{7}{*}{$\begin{array}{l}\text { SCHe systems in } \\
\text { Process Hood support } \\
\text { structure at the } \\
\text { mezzanine }\end{array}$} & Interconnected with heater, damper, filter, duct and fan. Qualified by analysis using $3 / 1$ seismic load per SD-30006. Accept. \\
\hline $30-2$ & H.1-1-82204 & HVAC-HTR $-8^{*} 04$ & Electrical Heater & GS & $\mathrm{PC}-1^{2}$ & $3 / 1$ & Frame & MEL.2621.EQ.04 & & Cooling coil and heater share the same supporr structure. Anchorage is adequate. \\
\hline $30-2$ & H-1.-82204 & HVAC-DMP- $8 * 01$ & Damper & Dess $=$ & SPE.2 & $3 / 1$ & Frame & 2288-S.011 & & Interconnected with heater, cooling coil, filter, duct and fan. Qualified by analysis using $3 / 1$ seismic load. Accept. \\
\hline 30.2 & H.1-82204 & HVACCF-8 802 & HEPA filter & GS & $\mathrm{PC}-1^{2}$ & $3 / 1$ & Frame & MEL.2621.EQ.03 & & Interconnected with heater, damper, cooling coil, duct and fan. Qualififed by analysis using $3 / 1$ seismic load. Accert. \\
\hline$\frac{30-2}{20-2}$ & $\frac{H-1-82204}{H-1.8204}$ & & pucting & GS & $\mathrm{PC}-1^{2}$ & $3 / 1$ & & & & 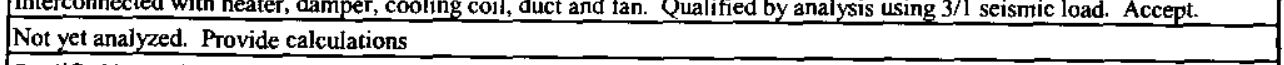 \\
\hline $30-2$ & $\mathrm{H}-1-82204$ & & Filler Housing \& Duct Supports & GS & $\mathrm{PC}-1^{2}$ & $3 / 1$ & Frame & MEL.2621.EQ.6 & & Qualified by analysis using $3 / 1$ seismic load. Accept. \\
\hline$\frac{30-2}{30.3}$ & H-1-82204 & HVVAC-FAN-8*05 & $\frac{\text { Fans }}{\text { FVent System (Sys. 30-3) }}$ & GS & ${\mathrm{PC}-1^{2}}^{2}$ & $3 / 1$ & Frame & MEL.2621.EQ.04 & & Interconnected with heater, damper, filter, duct and cooling coil. Qualified by analysis using $3 / 1$ seismic load. Accept. \\
\hline $30-3$ & H-1.-82206 - & HVAC-AMS-8044 & Air Flow Measuring Station & SS & PC-2.2 & $3 / 1$ & & & None & Located in Mechanical Room. There are no PC3 3 items in the room. No action reguired. \\
\hline$-\frac{30.3}{30.3}$ & $\frac{1-1-82206}{H-1-82206}$ & HVAC.F-8040 & HEPA filter & ss & $\mathrm{PC} \cdot 2^{2}{ }^{2}$ & $\frac{3 / 1}{3 / 1}$ & & & None & Located in Mechanical Room. There are no PCS items in the room. No action required. \\
\hline$\frac{30-3}{30-3}$ & H-1-822066 & & $\begin{array}{l}\text { Fuccing } \\
\text { Filter Housing \& Duct Supports }\end{array}$ & $\frac{S S}{s s}$ & $\frac{\mathrm{PC} \cdot 2^{2}}{\mathrm{PC} \cdot 2^{2}}$ & $\frac{31 / 1}{3 / 1}$ & & & $\frac{\text { None }}{N \text { Non }}$ & Located in Mechanical Room. There are no PC3 items in the room. No action required. \\
\hline 30.3 & $\mathrm{H}-1-82192 \mathrm{H}-1-8220$ & HVAC-DMP- $8 * 03$ & - & & & & & & None & Located in Mechanical Room. There are no PC3 items in the room. No action required. \\
\hline & & $\begin{array}{ll}\text { HVACDAMP-80.03 } \\
\text { HVAC-DMP-006,-007,- }\end{array}$ & famper & ss & $\mathrm{PC}-2^{2}$ & $3 / 1$ & & 2288-S.011 & None & Designed for $3 / 1$ loadings. Anchorage acceptable. \\
\hline$-\frac{30.3}{30-3}$ & H-1-82192 H-1-82206 & & $\begin{array}{l}\text { Dampers } \\
\text { Cask Venting/Purging Equipment } \\
\end{array}$ & $\frac{\text { ss }}{\text { ss }}$ & $\frac{\mathrm{PC}-2^{2}}{\mathrm{PC}-2}$ & $\frac{3 / 1}{3 / 1}$ & & & $\frac{\text { None }}{\text { None }}$ & 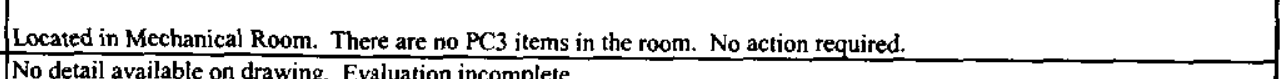 \\
\hline $30-3$ & H-1.82206 & HVAC-EXHF-8045, 8047 & Fans & $s s$ & & & & & None & \\
\hline & & CA-TK. $5 * 21$ & & $s \mathrm{SS}$ & PC. $-2^{2}$ & $3 / 1$ & & & None & Located in Mechanical Room. There are no PC3 items in the room. № action required. \\
\hline $\begin{array}{ll}30-3 \\
30-3 \\
\end{array}$ & $\begin{array}{l}\text { H-1-82206 } \\
\text { Process vent system }(S y\end{array}$ & $30-3\}$ & Compressed Air Tank & ss & $\mathrm{PC}-2$ & $3 / 1$ & mezzanine & & SCIC Panels & No construction drawing available. Tank vendor will provide anchorage calculation. Review calculation when provided. \\
\hline $30-3$ & H.1-82161 & PV-HOOD-1*12 & Process Hood & ss & $\mathrm{PC}-3$ & $3 / 1$ & Frame/Mezzanine & $2288-5.09 \mathrm{~A}, \mathrm{~B}, \mathrm{C}$ & \begin{tabular}{c|c|c|} 
Process Hood \& 1/4" \\
SCHe
\end{tabular} & $\begin{array}{l}\text { Process Hood support located on the mezzanine qualified by analysis as PC } 3 \text {. In Structure Response Spectra by Advent was } \\
\text { used. Anchorage acceppable. }\end{array}$ \\
\hline$\frac{30-3}{30-4}$ & H-1-82161 to-165 & ss General Supply] (Sys. 30-4) ${ }_{\text {NoS }}$ & $\begin{array}{l}\text { Pipe Supports } \\
\text { Ssoorsesses } \\
\end{array}$ & ss & $\mathrm{PC}-2$ & $3 / 1$ & Frame/Mezanine & 2288-S.015 & $1 / 4^{\prime \prime} \mathrm{SCHe}$ & Analysis did not use ISRS for the mezzanine. Some clamps are overloaded. Not acceppable. \\
\hline $30-4$ & H-1.1.82205 & HVAC-CCL-8004 & Cooling Coil & $\underline{\text { GS }}$ & $\mathrm{PC}-1^{2}$ & $3 / 1$ & & & None & $\begin{array}{l}\text { Located in Mechanical Roon. There are no } \mathrm{PC} 3 \text { items in the room. Should be } \mathrm{PC} 1 \mathrm{I} \text {. Both } \mathrm{PCl} \text { and } \mathrm{PC} 2 \text { use the same } \\
\text { seismic criteria so no action required. }\end{array}$ \\
\hline $30-4$ & H-1.-82205 & 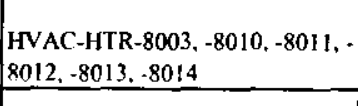 & Heater & GS & $\mathrm{PC}-1^{2}$ & $3 / 1$ & & & None & $\begin{array}{l}\text { Localed in mechanical Room. There are no PC3 items in the room. Should be PC } 1 / 2 \text {. Both } \mathrm{PCl} \text { and } \mathrm{PC} 2 \text { use the same } \\
\text { sismic critiria so o o action required. }\end{array}$ \\
\hline $30-4$ & H.1.-82205 & HVAC-AMS-8007 & Air Flow Measuring Station & Gs & ${\mathrm{PC}-\mathrm{I}^{2}}^{2}$ & $3 / 1$ & & & None & $\begin{array}{l}\text { Located in Mechanical Room. There are no PC3 items in the room. Should be PC } 1 / 2 \text {. Both PCI and PC2 use the same } \\
\text { seismic criteria so no action required. }\end{array}$ \\
\hline
\end{tabular}




\begin{tabular}{|c|c|c|c|c|c|c|c|c|c|c|}
\hline \multicolumn{11}{|c|}{ SEISMIC 3/1 ITEMS IDENTIFIED IN MASTER EQUIPMENT LIST } \\
\hline Sys. No. & P\&ID & Component Tag No. & Component Descriplion / Noun Name & 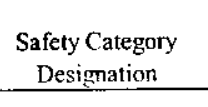 & $\begin{array}{l}\text { NPH and Performance } \\
\text { Category }\end{array}$ & Seismice & Support Typel Location & $\begin{array}{l}\text { Seesmic Calculation } \\
\text { Reference }\end{array}$ & S Safey Class Taryet & \\
\hline 30.4 & $\mathrm{H}-1.82205$ & IVNAS-AAN-800S & tans & is & $P(-)^{2}$ & $3 / 1 \cdot 1$ & & & Vone & 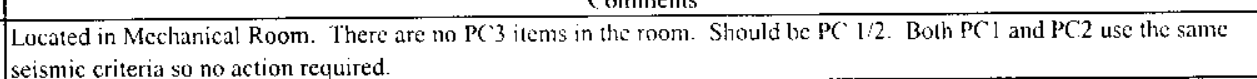 \\
\hline 30.4 & H-1.-82205 & HVAC-DMP-8001-8035 & Dampers & gs & $\mathrm{PC} \cdot 1^{\circ}$ & $3 / 1$ & & & None & 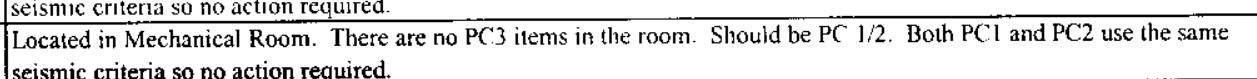 \\
\hline 30.4 & $\mathrm{H}-1.82205$ & HVAC.-8002 & HEPA filter & Gs & ${\mathrm{PC}-1^{2}}^{2}$ & $3 / 1$ & & & None & 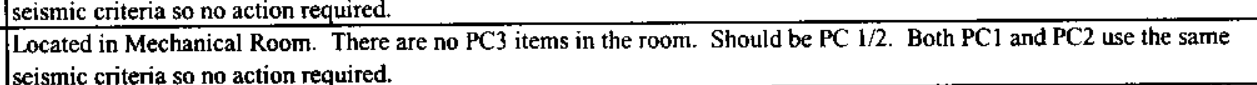 \\
\hline 30.4 & H.1-82205 & & Ducting & as & $\mathrm{PC}-1^{2}$ & $3 / 1$ & & & None & 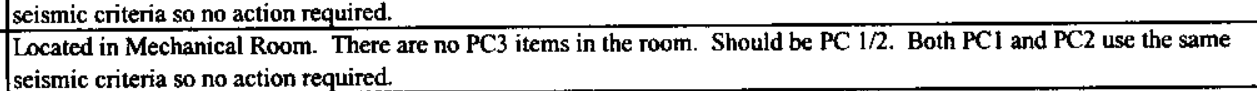 \\
\hline 30.4 & H.1.82205 & & Filiter Hosing & as & ${\mathrm{PC}-1^{2}}^{2}$ & $3 / 1$ & & & None & 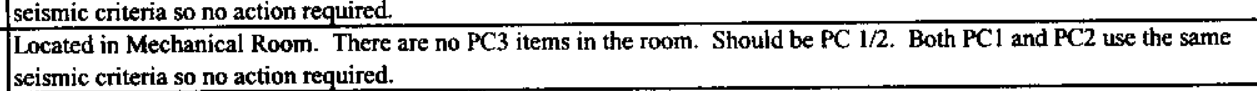 \\
\hline & H.1-82205 & & Duct Supports & Gs & $\mathrm{PC}-1^{2}$ & $3 / 1$ & & & None & \\
\hline$\frac{304}{304}$ & 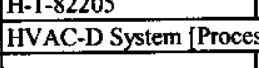 & ss General Exhauss] (Sys. 30-4) & & & & & & & & 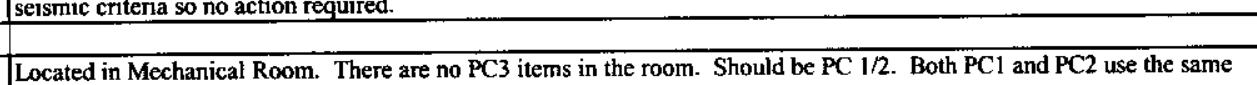 \\
\hline 304 & $\mathrm{H}-1-82206$ & HVAC-AMS-8024 & Air Flow Measuring Station & ss & $\mathrm{PC} \cdot 2^{2}$ & $3 / 1$ & & & None & \\
\hline 30.4 & H1-82206 & HVAC.F-8020 & HEPA filler & ss & $\mathrm{PC}-2^{2}$ & $3 / 1$ & & & None & 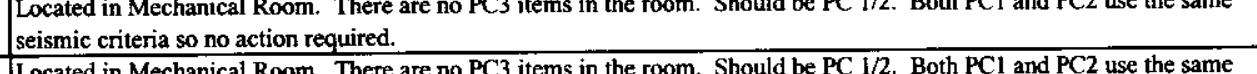 \\
\hline 30.4 & H-1.82206 & & Duccing & ss & PC. $2^{2}$ & $3 / 1$ & & & None & 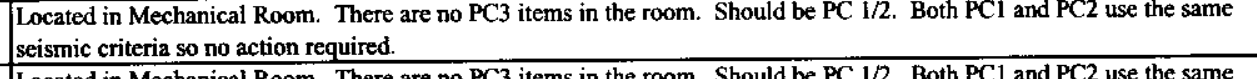 \\
\hline 304 & $\mathrm{H}-1-82206$ & & Filler Housing & ss & $\mathrm{PC}-2$ & $3 / 1$ & & & None & 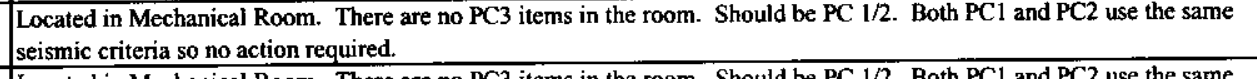 \\
\hline 304 & 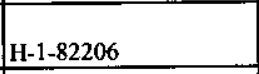 & & Duct Supports & ss & PC.2 2 & 311 & & & None & \\
\hline 304 & $\mathrm{H} 1.822206$ & HVAC-DMP- $8^{*} 02$ & Damper & ss & $\mathrm{PC}-2^{2}$ & $3 / 1$ & $22888-011$ & & None & 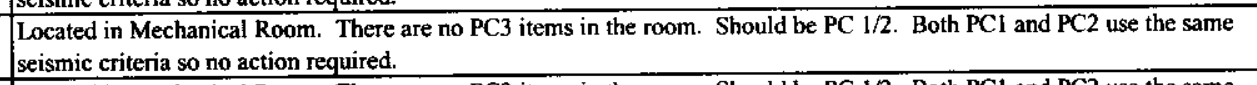 \\
\hline 30.4 & $\mathrm{H}-182206$ & HVAC-EXHF-8025,-8027 & Fans & as & $\mathrm{PC}-1^{2}$ & 3/1/ & & & None & 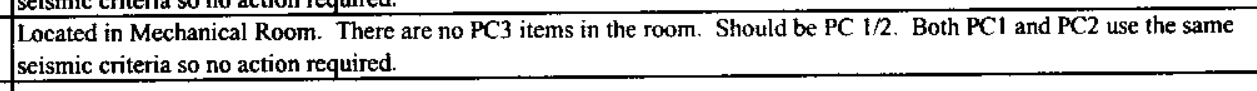 \\
\hline 30.5 & 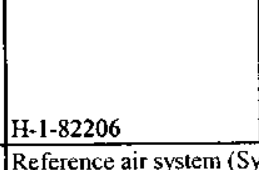 & 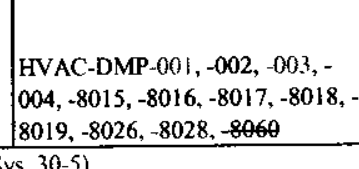 & Dampers & Gs & $\mathrm{PC}-2^{2}$ & $3 / 1$ & & & None & 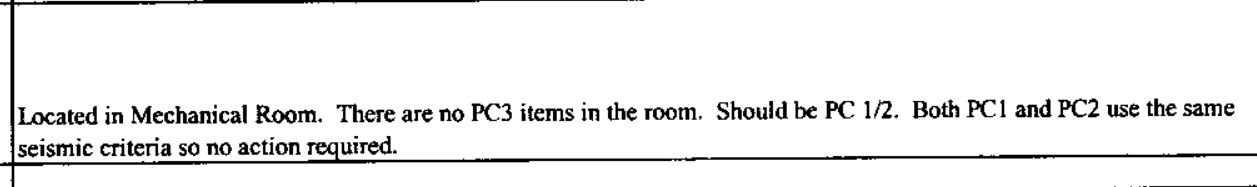 \\
\hline 46-5. & 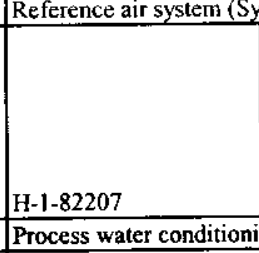 & & Pipe Suppors & Gs & $\mathrm{PC}-2$ & $3 / 1$ & H7, Trapeze & & sche-ST-1/4" \& Panel & 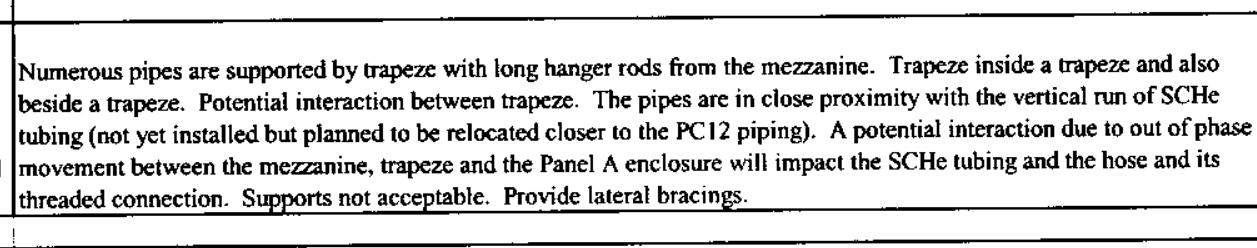 \\
\hline 46-1 & $\begin{array}{l}\text { Proceess water conditioni } \\
\text { H.1.82164 H.1.82223 }\end{array}$ & inipg system (SSy:-46-1) & 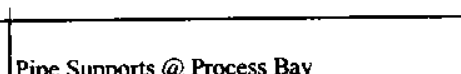 & & $\mathrm{PC} \cdot 2^{2}$ & 31 & н5, Н1-82225 & HNF-4291 & scic Control Panels & \\
\hline $46-1$ & H-1.-122164 H-1.-82223 & & Support Structure $Q$ Tank Room & ss & $\mathrm{PC}-2$ & $3 / 1$ & $\begin{array}{c}\mathrm{HS}, \mathrm{H}-1-82225 \\
\text { Tank Room }\end{array}$ & 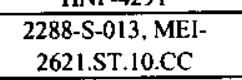 & \begin{tabular}{|c|c|} 
SCCIC Control Panels \\
None
\end{tabular} & 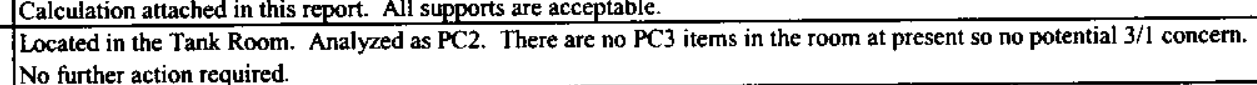 \\
\hline $46-1$ & 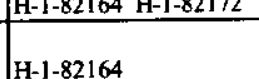 & PWC.FA042 & Filer & scisise & $\mathrm{PC}-2$ & $3 / 1$ & Tank Room & 2288.5.013 & None & 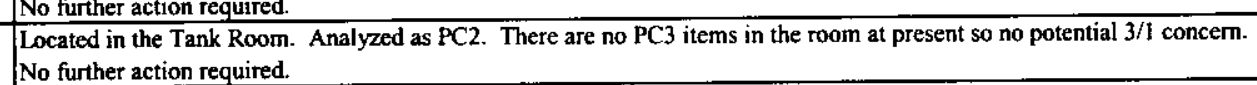 \\
\hline $46-1$ & H.1-182164 & Pwc. XXM-4037 & Ion Exchange Module & scclss & $\overline{\mathrm{PC} \cdot 2}$ & $3 / 1$ & Tank Room & 22288.5.013 & None & 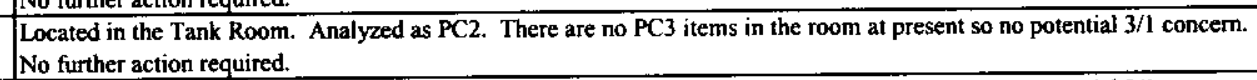 \\
\hline 46.1 & $\mathrm{H}-1.82164$ & PWC.-XM 4038 & Ion Exchange Module & scliss & PC.2. & 3/1 & Tank Room & 2288.5.013 & None & 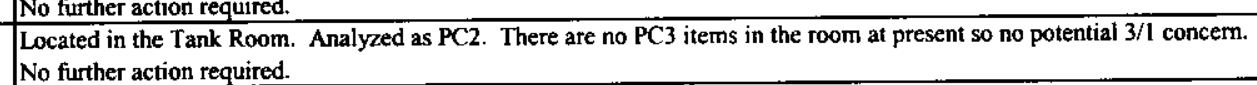 \\
\hline $46-1$ & H.1-82164 & PWC.TK-4032 & Receiver Tank & sc/ose & PC-2 & 311 & Tank Room & 2288.5.013 & None & 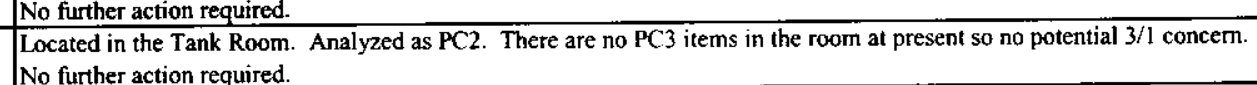 \\
\hline $46-1$ & H.1-1.82164 & PWC-TK 4033 & Receiver Tank & sc/ase & $\mathrm{PC} \cdot 2$ & $3 / 1$ & Tank Room & 2288-S-013 & None & 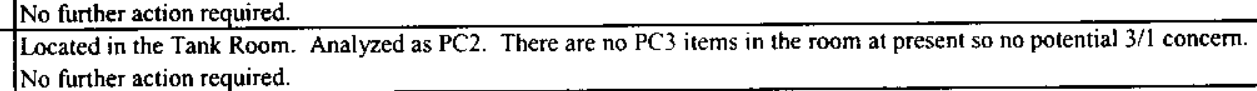 \\
\hline & & & & & & & & & & $\begin{array}{l}\text { Nof further action required. } \\
\text { Located in the Tank Room. Analyzed a s PC2. There are no PC3 items in the room at presen so no potential } 3 / 1 \text { concern. }\end{array}$ \\
\hline 6-1-1 & $\mathrm{H}-1-82164$ & PWC.EJR-4031 & Water Jet Ejector & cs & $\mathrm{PC} \cdot 2$ & $3 / 1$ & Tank Room & 2288.5013 & None & 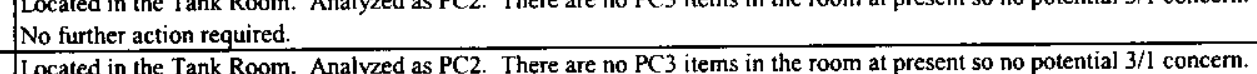 \\
\hline $46-1$ & $\mathrm{H}-1.82223$ & pwc-.001 & PWC Transporter Transfer Pump & Gs & $\mathrm{PC}-2$ & 3/1 & Tank Room & 22288.S-013 & None & 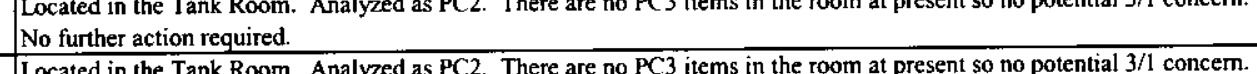 \\
\hline $46-1$ & H.1-82164 & PwC.P.4035 & Circulation Water Pump A & os & $\mathrm{PC}-2$ & 311 & Tank Room & 2288.5013 & None & 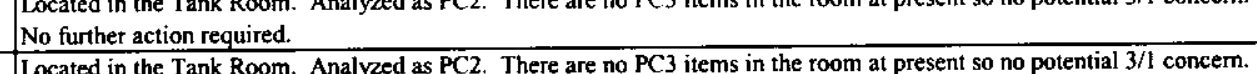 \\
\hline $46-1$ & H.1.828164 & PWC.P-4036 & Circulation Water Pump B & as & PC.2 & 311 & Tank Room & 2288.5.013 & None & \\
\hline $46-1$ & H.1.82223 & PWC.TK_4001 & Slorage tank & os & $\mathrm{PC}-2$ & $3 / 1$ & Tank Room & 2288.5.013 & None & 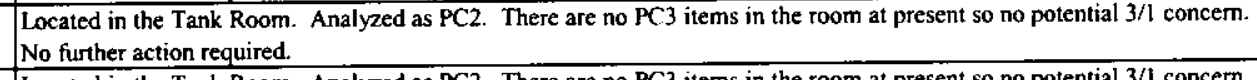 \\
\hline $46-1$ & H.-1.82223 & PWC-F.4043 & Storgage tank HEPA Filter & Gs & $\mathrm{PC}-2$ & $3 / 1$ & Tank Room & 2288.50.013 & None & 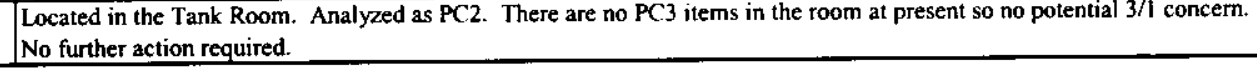 \\
\hline
\end{tabular}




\begin{tabular}{|c|c|c|c|c|c|c|c|c|c|c|}
\hline \multicolumn{11}{|c|}{ SEISMIC 3/1 ITEMS IDENTIFIED IN MASTER EQUIPMENT LIST } \\
\hline Sys. №. & P\&ID & Component Tag No. & Component Description / Noun Name & $\begin{array}{c}\text { Safety Category } \\
\text { Designation }\end{array}$ & $\begin{array}{l}\text { NPH and Performance } \\
\text { Catepory }\end{array}$ & Seismic $^{c}$ & Support Type/ Location & $\begin{array}{c}\text { Seismic Calculation } \\
\text { Reference }\end{array}$ & Safety Class Target & Comments \\
\hline$-\frac{46-1}{46-2}$ & $\begin{array}{l}111-1.82164 \text { H.1-1-82223 } \\
\text { Conditioned Water Ship }\end{array}$ & $\frac{1}{\text { ping System (Sys. } 46-2) \text { ito SS or }}$ & 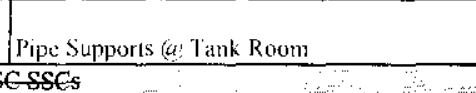 & Gis & $\mathrm{PC}-2$ & 3.1 & Tank Room & $2288-\mathrm{S}-013$ & Nonc & 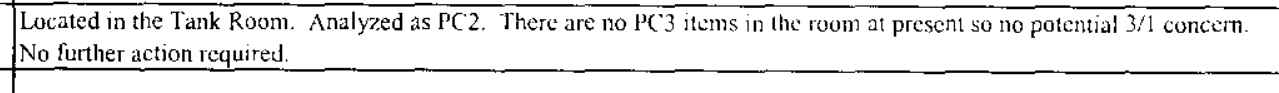 \\
\hline$\frac{46-2}{46-3}$ & Contaminated Water & mpling and Analysis (Sys.46-3) AN & 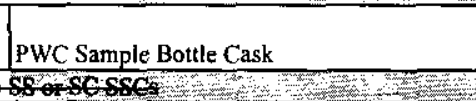 & as & $\mathrm{PC}-1^{2}$ & $3 / 1$ & Tank Room & 2288-S-013 & None & $\begin{array}{l}\text { Located in the Tank Room. Analyzed as PC2. There are no PC3 items in the room at present so no potential } 3 / \text { concern. } \\
\text { No further action required. }\end{array}$ \\
\hline $46-3$ & H-1.82164 & PWC-SMP-4039 & Automatic Sampler & GS & PC-2 & 3/1 & Tank Room & 2288-S.013 & None & $\begin{array}{l}\text { Iocated in the Tank Room. Analyzed as PC2. There are no PC3 items in the room at present so no potential } 3 / 1 \text { concern. } \\
\text { No further action reguired. }\end{array}$ \\
\hline $46-3$ & H-1-82164 & PWC-SMP-4040 & Automatic Sampler & GS & $\mathrm{PC}-2_{2}$ & $3 / 1$ & Tank Room & 2288-S-013 & None & $\begin{array}{l}\text { Located in the Tank Room. Analyzed as PC2. There are no PC3 items in the room at present so no potential } 3 / 1 \text { concerm. } \\
\text { No further action required. }\end{array}$ \\
\hline $46-3$ & $\mathrm{H}-1-82164$ & PWC-SMP-4041 & Automatic Sampler & GS & $\mathrm{PC}-2$ & $3 / 1$ & Tank Room & $2288-\mathrm{S}-013$ & None & $\begin{array}{l}\text { Located in the Tank Room. Analyzed as PC2. There are no } \mathrm{PC} 3 \text { items in the room at present so no potential } 3 / 1 \text { concerm. } \\
\text { No further action required. }\end{array}$ \\
\hline$\frac{46-3}{47-1}$ & $\frac{\text { H.1-1-82164 }}{\text { MCO-tempered water S }}$ & & Automatic Sampler Bottle & as & $\mathrm{PC}-2$ & $3 / 1$ & Tank Room & 2288-S-013 & None & $\begin{array}{l}\text { Located in the Tank Room. Analyzed as PC2. There are no PC } 3 \text { items in the room at present so no potential } 3 / \text { / concerm. } \\
\text { No further action required. }\end{array}$ \\
\hline $47-1$ & MCO-tempered waters & TW-CLR $-3 * 10$ & Cooler & as & $\mathrm{PC}-1^{2}$ & $3 / 1$ & Process Bay & $2288-\mathrm{S}-12,12 \mathrm{~A}$ & SCHe Panel A & 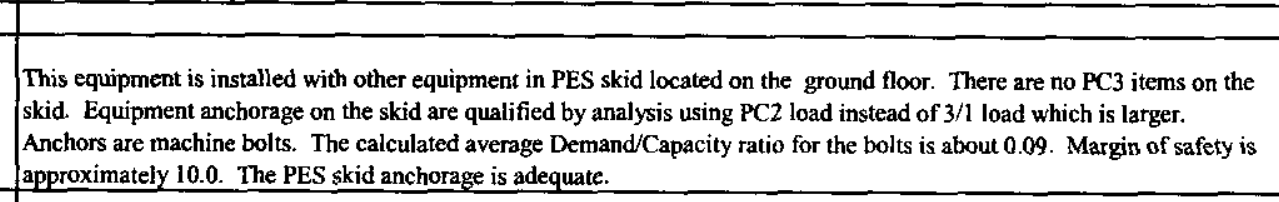 \\
\hline $47-1$ & $\mathrm{H}-1-82163$ & TW-HTR-3*11 & Heater & Gs & $\mathrm{PC}-1^{\mathrm{a}}$ & $3 / 1$ & Process Bay & $2288-\mathrm{S}-12,12 \mathrm{~A}$ & SCHe Panel A & 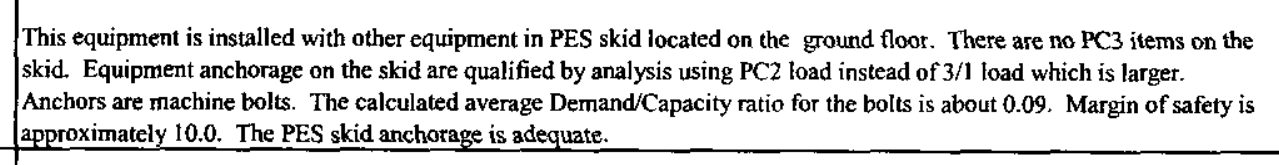 \\
\hline $47-1$ & H-1-82163 & TW-P.-3*14 & Pump. & GS & $\mathrm{PC}-1^{2}$ & $3 / 1$ & Process Bay & $2288-\mathrm{S}-12,12 \mathrm{~A}$ & SCHe Panel A & 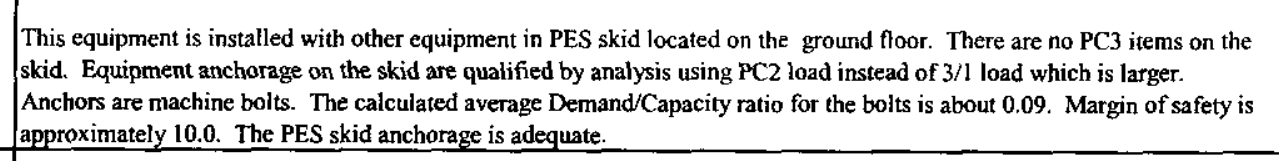 \\
\hline $47-1$ & Hail & TW-TK-3* $3^{*}$ & Expansion Tank & GS & $\mathrm{PC}-\mathrm{I}^{2}$ & $3 / 1$ & Process Bay & $2288-\mathrm{S} \cdot 12,12 \mathrm{~A}$ & SCHe Panel A & 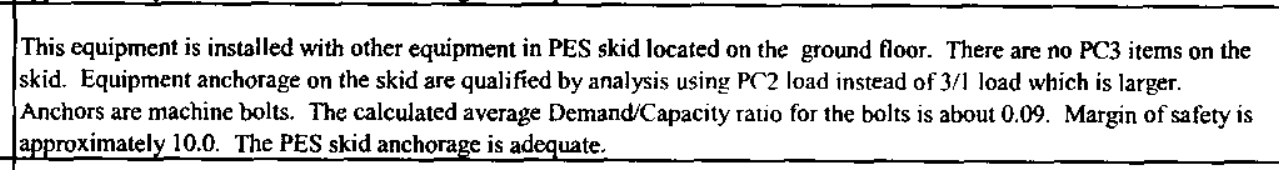 \\
\hline $47-1$ & $\begin{array}{l}\mathrm{H}-1-82241,-242,-246,- \\
247,-248\end{array}$ & & TW Heater SCR's (@ Process Bay) & GS & $\mathrm{PC}-1^{2}$ & $3 / 1$ & Process Bay & $2288-\mathrm{S}-12,12 \mathrm{~A}$ & SCHe Panel A & This recorder is installed on the wall away from the SCHe Panel. Acceptable. \\
\hline$\frac{-47-1}{47-2}$ & $\frac{\mathrm{H}-1-82161 \&-163}{\text { Tempered water coo }}$ & n (sys: 4/.2] & Pripe Support@ @ PES skid & Gs & $\mathrm{PC}-1^{2}$ & $3 / 1$ & Process Bay & $2288-\mathrm{S}-12,12 \mathrm{~A}$ & SCHe Panel A & 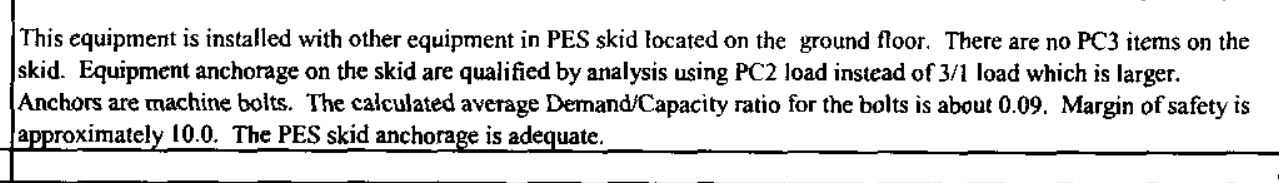 \\
\hline$\frac{47-2}{-47-3}$ & H-1-82224 & 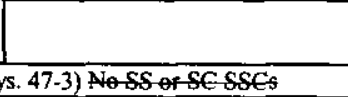 & Fipe Supports & Gs & $\mathrm{PC}-1$ & $3 / 1$ & & & & $\begin{array}{l}\text { All of hhe 47-2 piping systems in the MEL piping section are not } 3 / \text { th therefore pipe supports should not be } 3 / 1 \text { item. Revise } \\
\text { MEL to agree. }\end{array}$ \\
\hline$\frac{47-3}{47-4}$ & $\begin{array}{ll}\text { H-1-182208 } \\
\text { VPS chilled water systern }\end{array}$ & 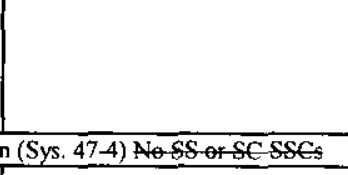 & Pipe Supports & GS & 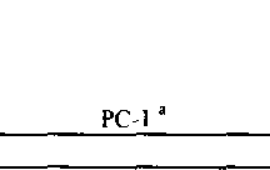 & $3 / 1$ & Mezzanine & MEI-2621.EQ.01 & None & 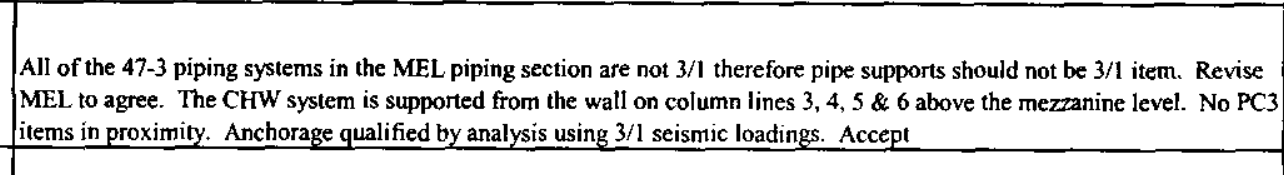 \\
\hline$-\frac{47-4}{93-1}$ & 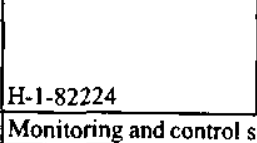 & 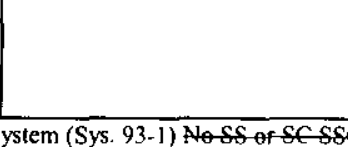 & Pipe Supports & GS & $P C-1^{2}$ & $3 / 1$ & & & None & 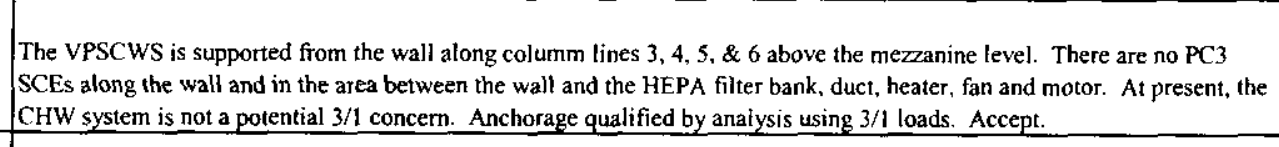 \\
\hline $93-1$ & H.1-82291 & & Remote VO Cabinets & GS & $\mathrm{PC}-1^{2}$ & $3 / 1$ & Process Bay & HNF-4291 & SCHe Panel B & Anchorage evaluation attached herein. Anchorage not adequate. Frovide additional lateral restraint. \\
\hline 93-1 & $\mathrm{H}-1-82291$ & & Conduit supports & GS & $\mathrm{PC}-1^{\mathrm{O}}$ & $3 / 1$ & & & & $\begin{array}{l}\text { The conduits and conduit supports are now PC3 per DCN-222. Provide support calculations using the mezzanine ISRS for } \\
\text { PC3 DBE. }\end{array}$ \\
\hline$\frac{100}{100}$ & Specialty Equipment (Sy & 5.100) & Swipe Count $\mathrm{f}$ & GS & 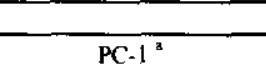 & $3 / 1$ & & & & 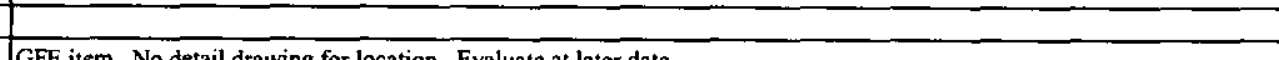 \\
\hline 100 & & & $\begin{array}{l}\text { Cask Lid Storage Fixture (seal replacement } \\
\text { and lid decon) }\end{array}$ & as & 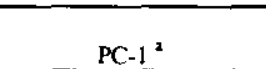 & $3 / 1$ & & & & GFF item No detaid drawing for location. Evaluate a later date. \\
\hline 100 & & & Cask Trailer Bumper & GS & $\mathrm{PC-1} \mathrm{I}^{\mathrm{2}}$ & $3 / 1$ & & & & GFE \\
\hline 100 & & & Cask Trailer Wheel Chocks & GS & 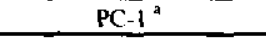 & 3/1 & & & & GFE item. № detail drawing for location. Evaluate a l later date. \\
\hline
\end{tabular}




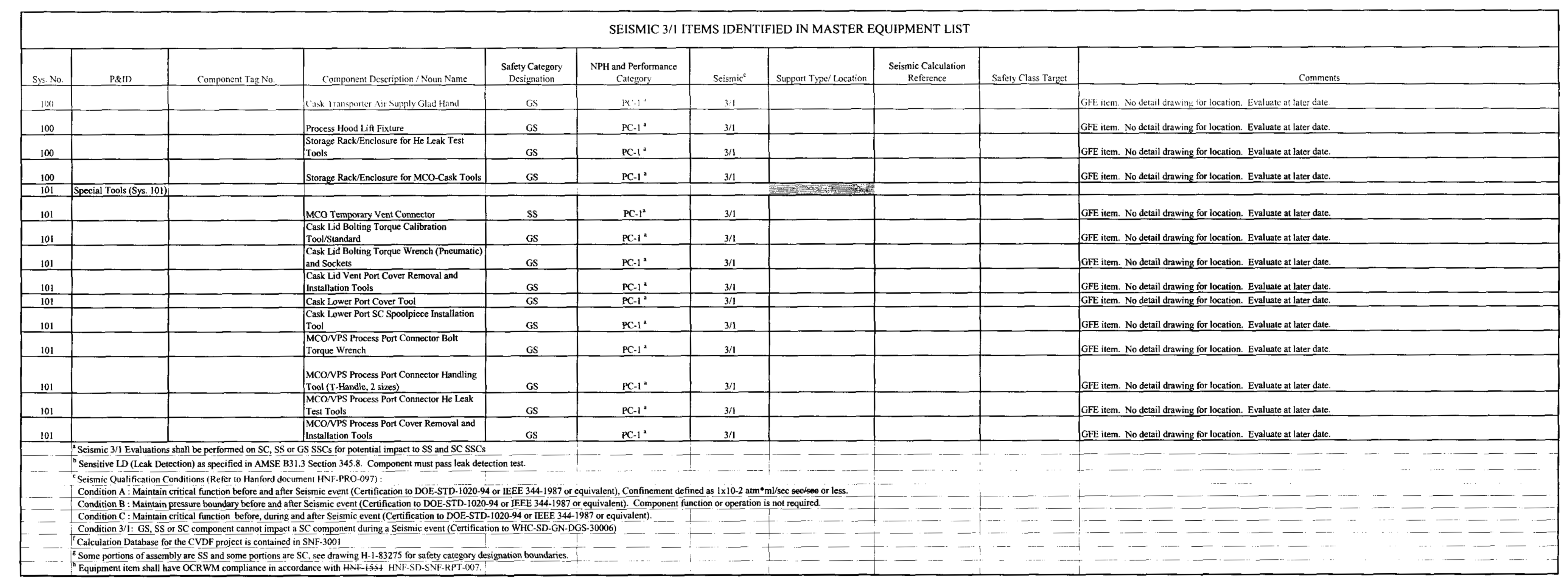




\begin{tabular}{|c|c|c|c|c|c|c|c|c|c|}
\hline \multicolumn{10}{|c|}{ SEISMIC $3 / 1$ ITEMS IDENTIFIED IN MASTER EQUIPMENT LIST } \\
\hline$\frac{\mathrm{Sys} . \mathrm{N}_{0} .}{07}$ & $\frac{\text { P\&iD }}{\text { Vacuum Purge system? }}$ & $\frac{1 \text { Component lag No. }}{1 \text { (S) }}$ & Componem Descrerpion Noun Name & $\begin{array}{l}\text { Safety Catconory } \\
\text { Designation }\end{array}$ & $\begin{array}{c}\text { XPlt and Performance } \\
\text { Calegory }\end{array}$ & Seismic & Safery Class Target & \begin{tabular}{|l|} 
Seismic Caicularion Reterence \\
\end{tabular} & Comments \\
\hline & 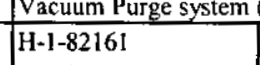 & $T_{1}^{l(S 58.07)}$ & & & & & & & \\
\hline $07-1$ & $\mathrm{H}-1-82162$ & VPS-*02-SS-2" & Vacuum Purge System & GS from GOV.1*05 & PC-1 ${ }^{2}$ from GOV $-1 * 05$ & $3 / 1$ & SCHe system & 2288-S-12 & Installed in PES skid. SC target not within zone of influence. \\
\hline 07.1 & $\mathrm{H}-1-82162$ & VPS-*03-SS-2" & Vacuum Purge System & GS & ${\mathrm{PC}-1^{2}}^{2}$ & $3 / 1$ & SCHe system & $2288-S-12$ & Installed in PES skid. SC target not within zone of influence. \\
\hline $07-1$ & $\mathrm{H}-1-82162$ & VPS-*04-SS-1" & Vacuum Purge System & GS & ${\mathrm{PC}-1^{2}}^{2}$ & $3 / 1$ & SCHe system & $2288-\mathrm{S}-12$ & Installed in PES skid. SC target not within zone of influence. \\
\hline 07.1 & $\mathrm{H}-1-82162$ & VPS-*07-SS-1" & Vacuum Purge System & GS & ${\mathrm{PC}-1^{\circ}}^{\circ}$ & $3 / 1$ & SCHe system & $2288-\mathrm{S}-12$ & Installed in PES skid. SC target not within zone of influence. \\
\hline $07-1$ & $\mathrm{H}-1-82162$ & VPS-"08-SS-2" & Vacuum Purge System & GS & $\mathrm{PC}-1^{\mathrm{a}}$ & $3 / 1$ & SCHe system & $2288-\mathrm{S}-12$ & Installed in PES skid. SC target not within zone of influence. \\
\hline 07.1 & $\mathrm{H}-1-82162$ & VPS-*09-SS-1" & Vacuum Purge System & GS & $\mathrm{PC-1}{ }^{2}$ & $3 / 1$ & SCHe system & $2288-\mathrm{S}-12$ & Installed in PES skid. SC target not within zone of influence. \\
\hline $07-1$ & $\mathrm{H}-1-82162$ & VPS-*10-SS-2" & \begin{tabular}{|l} 
Vacuum Purge System \\
\end{tabular} & Gs & ${\mathrm{PC}-1^{2}}^{2}$ & $3 / 1$ & SCHe system & $2288 \cdot S-12$ & IInstalled in PES skid. SC target not within zone of influence. \\
\hline $07-1$ & $H-1-82162$ & VPS-**11-SS-1" & Vacuum Purge System & GS & $\mathrm{PC}-1^{2}$ & $3 / 1$ & SCHe system & $2288-\mathrm{S}-12$ & Installed in PES skid. SC target not within zone of influence. \\
\hline $07-2$ & RGM system (Sys. 07-2 & & & & $=1$ & & & & \\
\hline $07-2$ & $\mathrm{H}-1-82162$ & VPS-**12-ST-1/4" & Vacuum Purge System - RGA Inlet & Gs & $\mathrm{PC}-1^{2}$ & $3 / 1$ & sCHe system & 2288-S-12 & Source is small. Accept \\
\hline $07-2$ & $\mathrm{H}-1-82162$ & VPS-*13.ST-1/4" & Vacuum Purge System - RGA Outlet & os & $\mathrm{PC}-1^{2}$ & $3 / 1$ & SCHe system & 2288-S. 12 & Source is small. Accept \\
\hline$\frac{07.3}{07.3}$ & He MSLD and Auxiliar & ary Vacuum system (Sys. 07-3) & TSIDIS & $G S$ & 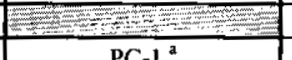 & $3 / 1$ & & & \\
\hline$\frac{12}{12}$ & Compressed and instrut & VIPS-tbd & |MSLD Line & $G S$ & $\frac{\mathrm{PC}-1^{2}}{\mathrm{~F}}$ & $3 / 1$ & & & No data, Evaluate at later date. \\
\hline 12 & $\mathrm{H}-1-82161,165$ & HcA & Compressed Air & as & $\mathrm{PC}-1^{2}$ & $3 / 1$ & SCHe system & No Calc. & See comment in Table A-1A for Sys. No. 12. \\
\hline 12 & H.1-82161 & $\mid A-* 01-S S-1^{n}$ & Instrument Air to PES Skid & GS & $\mathrm{PC}-1^{2}$ & $3 / 1$ & SCHe system & No Calc. & See comment in Table A-1A for Sys. No. 12 . \\
\hline 12 & H-1-82161 & IA-*02-ST-1/4" & Instrument Air to Seal Ring & as & $\mathrm{PC}-1^{2}$ & 3/1 & MCO Hood & No Calc. & Source is small. Accept \\
\hline 12 & $\mathrm{H}-1-82161$ & IA-*03-SS-1" & Instrument Air from PES Skid to Hood Assy. & as & ${\mathrm{PC}-1^{2}}^{2}$ & $3 / 1$ & SCHe system & $\mathrm{N} / \mathrm{A}$ & Flex hose. Accept \\
\hline 12 & $\mathrm{H}-1-82164$ & IA-(0)1-SS-1/2" & Instrument Air Suppiy to PWC skid & as & $\mathrm{PC}-1^{*}$ & $3 / 1$ & ScIC Panel & No Calc. & Source is smail. Accept \\
\hline 12 & $\mathrm{H}-1-82164$ & IA-002-SS-1/2n & Instrument Air Supply to PWC skid & GS & $\mathrm{PC}-\mathrm{I}^{2}$ & 3/1 & SCIC Panel & No Calc. & Source is small. Accept \\
\hline$\frac{13}{13-1}$ & \begin{tabular}{|l} 
Helium systems SSys. I \\
General Service Heliun
\end{tabular} & $\frac{13)}{\text { i. }}$ & & & $=0$ & & & & \\
\hline $13-1$ & $\mathrm{H}-1-82161$ & He-*01-SS-1" & General Service Helium Supply on PES Skid & GS to FE-1*21 & $\mathrm{PC}-1^{\mathrm{2}}$ & $3 / 1$ & SCHe system & 2288-S-12 & $\begin{array}{l}\text { Segment installed in process hood support is OK. Portion Installed in PES skid is OK. } \\
\text { Accept. }\end{array}$ \\
\hline $13-1$ & $\mathrm{H}-1-82222$ & He-*01-SS-1" & General Service Helium Supply in Bays & Gs & $\mathrm{PC}-1^{*}$ & $3 / 1$ & ScHe system & No Calc. & See comment in Table A-1A for System No. 13-1 \\
\hline 13-1 & $\begin{array}{l}\mathrm{H}-1-82222 \\
82161\end{array}$ & He-101-Ss-3/4" & General Service Helium Supply to Bays & Gs & $\mathrm{PC}-\mathrm{I}^{2}$ & $3 / 1$ & SCHe system & No Calc. & Not in process bay. Accept. \\
\hline 13-1 & $\mathrm{H}-1-82222$ & He-" 01 -SS-1/2" & General Service Helium Supply in Bays & GS & $\mathrm{PC}-1^{2}$ & $3 / 1$ & sCHe system & No Cak. & See comment in Table A-1A for System No. 13-1 \\
\hline $13-1$ & $\mathrm{H}-1-8216 !$ & He-*02-ST-1/4" & General Service Helium Supply for Cask Purge & GS & $\mathrm{PC}-1^{2}$ & $3 / 1$ & SCHe system & $2288-12$ & Source is small. Accept \\
\hline $13-1$ & 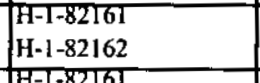 & He $-03-$-SS-1" & $\begin{array}{l}\text { General Service Hellum Supply to PES Skid4 } \\
\text { Psig Service }\end{array}$ & Gs & $\mathrm{PC}-1^{*}$ & $3 / 1$ & sCHe system & 22288-S-12 & Installed in PES skid. Accept. \\
\hline $13 \cdot 1$ & $\begin{array}{l}\mathrm{H}-\mathrm{-}-82161 \\
\mathrm{H}-1-82162 \\
\end{array}$ & He-*04-ST-1/4" & $\begin{array}{l}\text { Génera Servicec Helium Supply to PES Skid } \\
\text { vacuum Pump Ballast }\end{array}$ & Gs & ${\mathrm{PC}-1^{2}}^{2}$ & $3 / 1$ & SCHe system & $2288-S-12$ & Source is small. Accept \\
\hline $13-1$ & 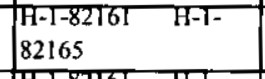 & He-*0S-SS-1/2" & General Service Helium Supply to SCHe & Gs & ${\mathrm{PC}-1^{2}}^{2}$ & $3 / 1$ & SCHe system & No Calc. & Source is small. Accept \\
\hline 13-1 & 82165 & He.*06-SS-1/2" & General Service Helium Supply to SCHe & as & $\mathrm{PC}-\mathrm{I}^{2}$ & $3 / 1$ & SCHe system & No Calc. & Source is small. Accept \\
\hline $13-1$ & $\mathrm{H}-1-82165$ & He-*07-ST-1/2" & General Service Helium Supply to SCHe & os & $\mathrm{PC}-1^{2}$ & $3 / 1$ & SCHe system & No Calc. & Source is small. Accept \\
\hline $13-1$ & H.1-82165 & He-*08-ST-1/2" & General Service Helium Supply to SCHe & GS & $\mathrm{PC}-\mathrm{I}^{2}$ & $3 / 1$ & sCHe system & No Calc. & Source is small. Accept \\
\hline $13-1$ & $\mathrm{H}-1-82165$ & He-*09-ST-1/2" & $\begin{array}{l}\text { General Service Hellum Supply to MCO DI Ilush } \\
\text { line }\end{array}$ & as & $\mathrm{PC}-\mathrm{I}^{2}$ & $3 / 1$ & SCHe system & No Calc. & Source is small. Accept \\
\hline 13-1 & $\mathrm{H}-1-82222$ & He-001-SS-1" & 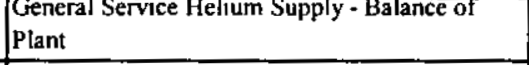 & Gs & $\mathrm{PC}-\mathrm{I}^{\mathrm{*}}$ & $3 / 1$ & sCHe system & No Calc. & See comment in Table A-1A for System No. 13-1 \\
\hline 19 & Condensate collectio & system (Sys. 19) & & & & & & & \\
\hline
\end{tabular}


SEISMIC 3/1 ITEMS IDENTIFIED IN MASTER EQUIPMENT LIST

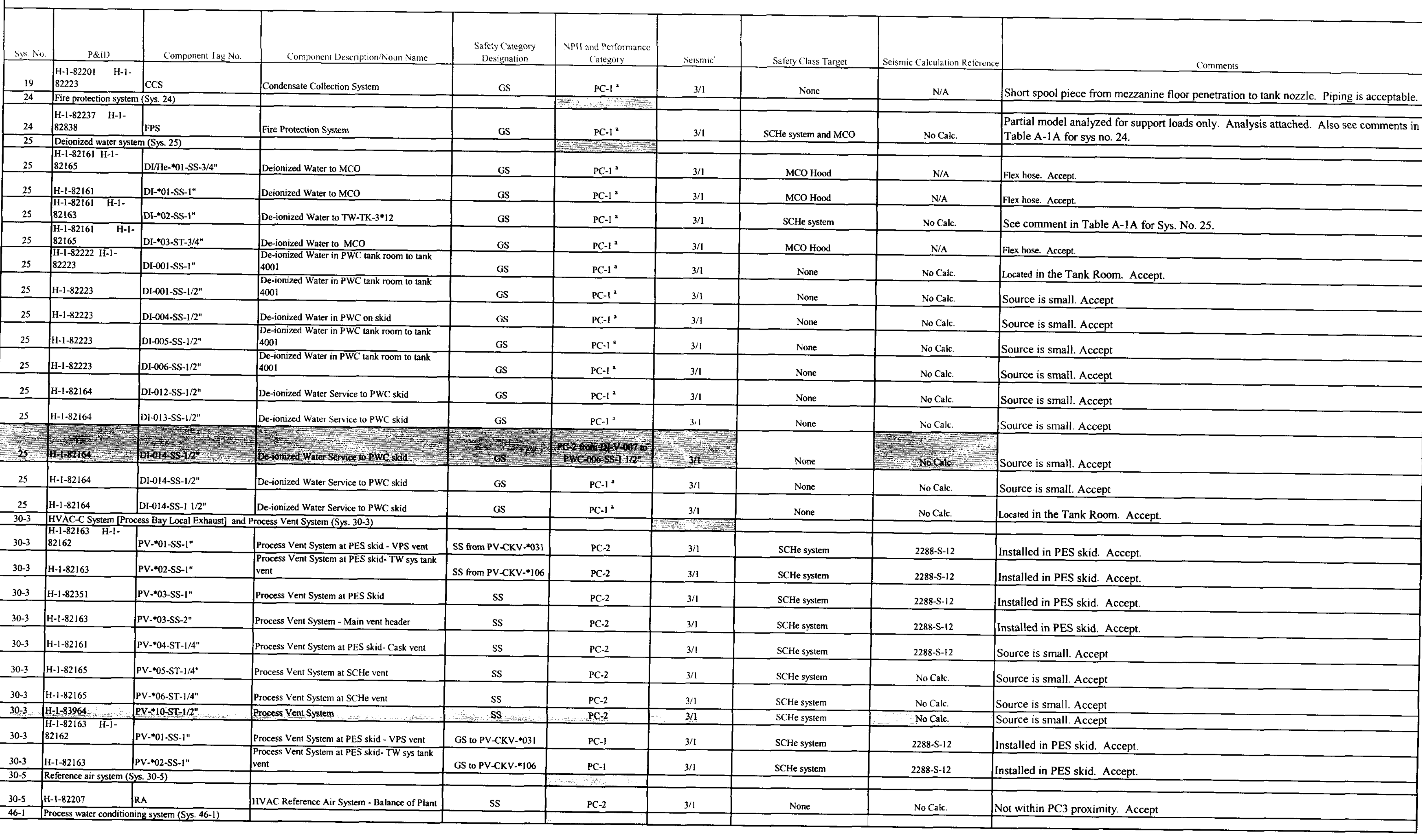


SEISMIC 3/1 ITEMS IDENTIFIED IN MASTER EQUIPMENT LIST

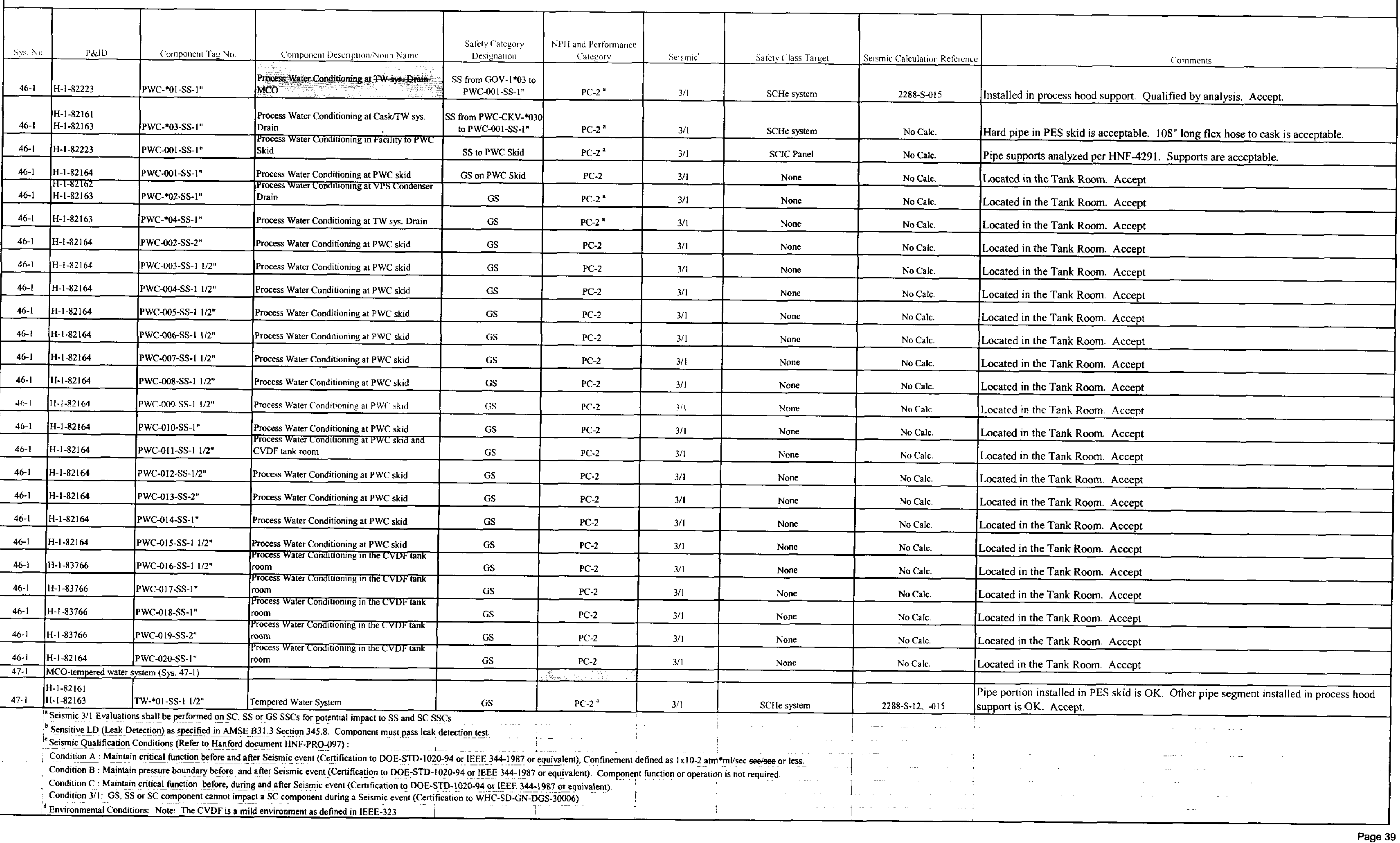




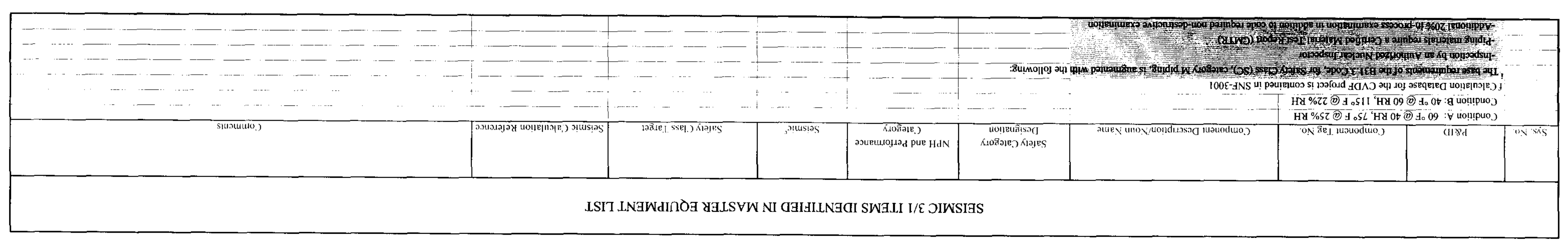

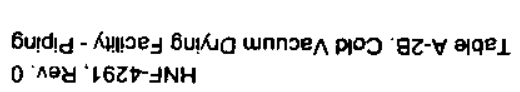


Table A-4B. Cold Vacuum Dning Facility - Instrumentation and Control

SEISMIC 3/1 ITEMS IDENTIFIED IN MASTER EQUIPMENT LIST

\begin{tabular}{|c|c|c|c|c|c|c|c|c|c|}
\hline \multicolumn{10}{|c|}{ SEISMIC 3/1 ITEMS IDENTIFIED IN MASTER EQUIPMENT LIST } \\
\hline Sys. No & P\&ID & Component Tag No. & Component Noun Name & $\begin{array}{c}\text { Safety Category } \\
\text { Designation }\end{array}$ & $\left|\begin{array}{c}\mathrm{NPH} \text { and } \\
\text { Performance (ategory }\end{array}\right|$ & Seismic & Safety Class Target & $\begin{array}{c}\text { Seismic Calculation } \\
\text { References }\end{array}$ & Comments \\
\hline $07-1$ & $11-1-82101$ & $\operatorname{siT}-1 * 07$ & MCO-SHT-TB-TEMP-XMITR & GS & $\mathrm{PC}-1$ & $3 / 1$ & SCHe system & None & Source is small or no PC3 within zonc of influence. Accept \\
\hline $07-1$ & $\mathrm{H}-1-82162$ & TIT-2*14 & VPS-COND-OUTLET-TEMP-XMITR & Gs & $\mathrm{PC}-1$ & $3 / 1$ & SCHe system & None & Source is small or no PC3 within zone of influence. Accept \\
\hline$\frac{07-1}{07-2}$ & 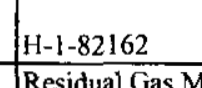 & TIT- $2 * 15$ & VPS-VAC-PUMP-DISCH-TEMP-XMITR & GS & $\mathrm{PC}-1$ & $3 / 1$ & SCHe system & None & Source is small or no $\mathrm{PC} 3$ within zone of influence. Accept \\
\hline $07-2$ & $\mathrm{H}-1-82162$ & ring system (Sys. $\frac{07-2)}{\mathrm{AE}-2 * 13}$ & VPS-RGA-ANAL-ELE & GS & $\mathrm{PC}-1^{2}$ & $3 / 1$ & SCHe system & None & Source is small or no PC3 within zone of influence. Accept \\
\hline$\frac{07-2}{12}$ & \multicolumn{2}{|c|}{ Compressed and instrument air system (Sys. 12) } & VPS-RGA-ANAL-XMITR & GS & ${\mathrm{PC}-1^{2}}^{2}$ & $3 / 1$ & SCHe system & None & Source is small or no $\mathrm{PC} 3$ within zone of influence. Accept \\
\hline$\frac{12}{30-5}$ & $\frac{\mathrm{H}-1-82161}{\text { Reference air sv }^{-}}$ & PIT- $1 * 04$ & CASK-SEAL-RING-IA-PRES-XMITR & Gs & $\mathrm{PC}-1$ & $3 / 1$ & SCHe system & None & Source is small or no PC3 within zone of influence. Accept \\
\hline$\frac{30-5}{30-5}$ & \multicolumn{2}{|c|}{$\frac{1}{\text { Reference air system(Sys. 30-5) }}$} & & 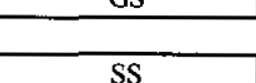 & $\overline{\mathrm{PC}-2}+2 \mathrm{C}$ & $3+1$ & & & \\
\hline $30-5$ & $\mathrm{H}-1-82207$ & PDDF $82208+20$ & BAYZ PRESSUT⿱一土丷 & SS & $\frac{\mathrm{PC}-2}{\mathrm{PC}-2}$ & $\frac{3 / 1}{3 / 1}$ & $\begin{array}{l}\text { SCHe system } \\
\text { SCHe system }\end{array}$ & $\begin{array}{l}\text { None } \\
\text { None }\end{array}$ & $\begin{array}{l}\text { Source is small or no PC3 within zone of influence. Accept } \\
\text { Source is small or no PC3 within zone of influence. Accept }\end{array}$ \\
\hline $30-5$ & H-1-82207 & PDIT-8080 & TANK RM PRESSURE (NEGATIVE) & ss & PC-2 & 3/1 & SCHe system & None & Source is small or no PC3 within zone of influence. Accent \\
\hline $30-5$ & $\mathrm{H}-1-82207$ & 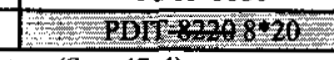 & BAY3PRESSURF (NEGATIVE) & SS & $\mathrm{PC}-2$ & $3 / 1$ & SCHe system & None & $\begin{array}{l}\text { Source is small or no PC3 within zone of influence. Accept } \\
\text { A }\end{array}$ \\
\hline 47.4 & \multicolumn{2}{|c|}{ VPS chilled water system (Sys. 47-4) } & & & & & & & \\
\hline $47-4$ & $\mathrm{H}-1-82162$ & TITT-2*35 & VPSCHW-COND-TK-DISCH-TEMP-XMITR & GS & PC-1 & 3/1 & SCHe system & None & Source is small or no PC3 within zone of influence. Accept \\
\hline \multirow[t]{2}{*}{$47-4$} & H-1-82162 & TाT- $2 * 36$ & $\begin{array}{l}\begin{array}{l}\text { VisCHW Condenser Outlet Temperature } \\
\text { Indicator/Transmitter }\end{array} \\
\end{array}$ & GS & $\mathrm{PC}-1$ & $3 / 1$ & SCHe system & None & Source is small or no PC3 within zone of influence. Accept \\
\hline & \multicolumn{4}{|c|}{ Seesmic 3/1 Evaluations shall be performed on SC, SS or GS SSCs for potential impact to SS and SC SSCs } & -7 & 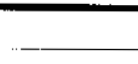 & - & & \\
\hline- & 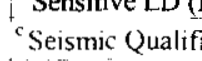 & $\begin{array}{l}\text { Detection) as specified in AN } \\
\mathrm{n} \text { Conditions (Refer to Hanfo }\end{array}$ & $\begin{array}{l}\text { E B31.3 Section 345.8. Component must pass leak detection } \\
\text { I document HNF-PRO-097): }\end{array}$ & 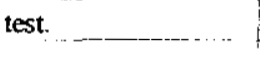 & $-\cdots$ & $\ldots \ldots$ & & - & .......... \\
\hline & Condition $\mathrm{A}: \mathrm{A}$ & ain critical function be & after Seismic event (Certification to DOE-STD-1020-94 & 344-1987 or & valent), Confineme & das $1 x$ & or & & \\
\hline$-\cdot$ & $\begin{array}{l}\text { Condition } B: 1 \\
\text { Condition } C: \Lambda\end{array}$ & $\begin{array}{l}\text { ain pressure boundary before } \\
\text { ain critical function before, } d\end{array}$ & $\begin{array}{l}\text { di after Seismic event (Certification to DOE-STD-1020-94 } \\
\text { ring and after Seismic event (Certification to DOE-STD-1026 }\end{array}$ & $\begin{array}{l}\text { IEEE 344-1987 or eq } \\
-94 \text { or IEEE } 344-1987\end{array}$ & fuivalent). Component fu & nction or ope & $n$ is not required. & - & $\square-\square-\square-\square$ \\
\hline & Condition 3/1: & $S S$ or SC component cannot i & pact a SC component during a Seismic event (Certification to & WHC-SD-GN-DGS-3 & & & & - - & + +—-. \\
\hline & ${ }^{d}$ Environmental & itions: Note: The CVDF is a & nild environment as defined in IEEE- 323 & 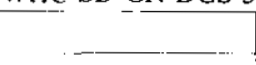 & $-\infty$ & - & & - & 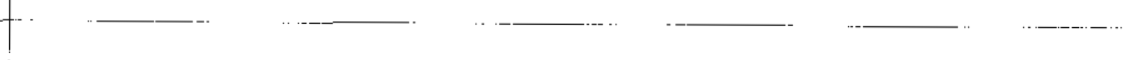 \\
\hline$\ldots$ & \begin{tabular}{|l|} 
Condition A: 6 \\
Condition B: 4
\end{tabular} & $\begin{array}{l}@ 40 \mathrm{RH}, 75^{\circ} \mathrm{F} @ 25 \% \mathrm{RH} \\
0.60 \mathrm{RH}, 115^{\circ} \mathrm{F} @ 22 \% \mathrm{RH}\end{array}$ & & & & & & & \\
\hline - & if Calculation Dat & for the CVDF project is con & ined in SNF-3001 & & & & …-- & & $-\cdots$ \\
\hline
\end{tabular}


HNF-4291, Rev, 0

APPENDIX A 


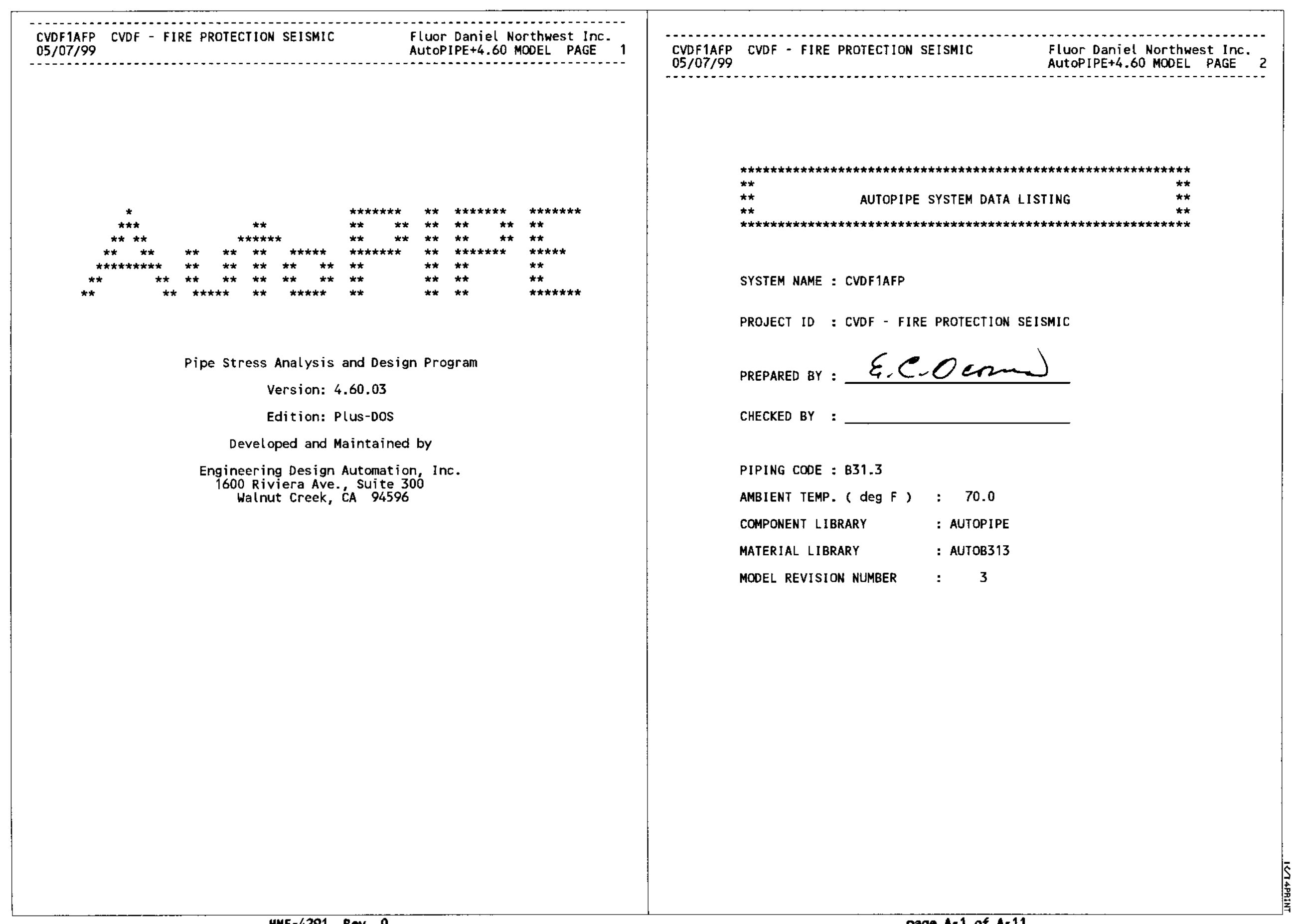




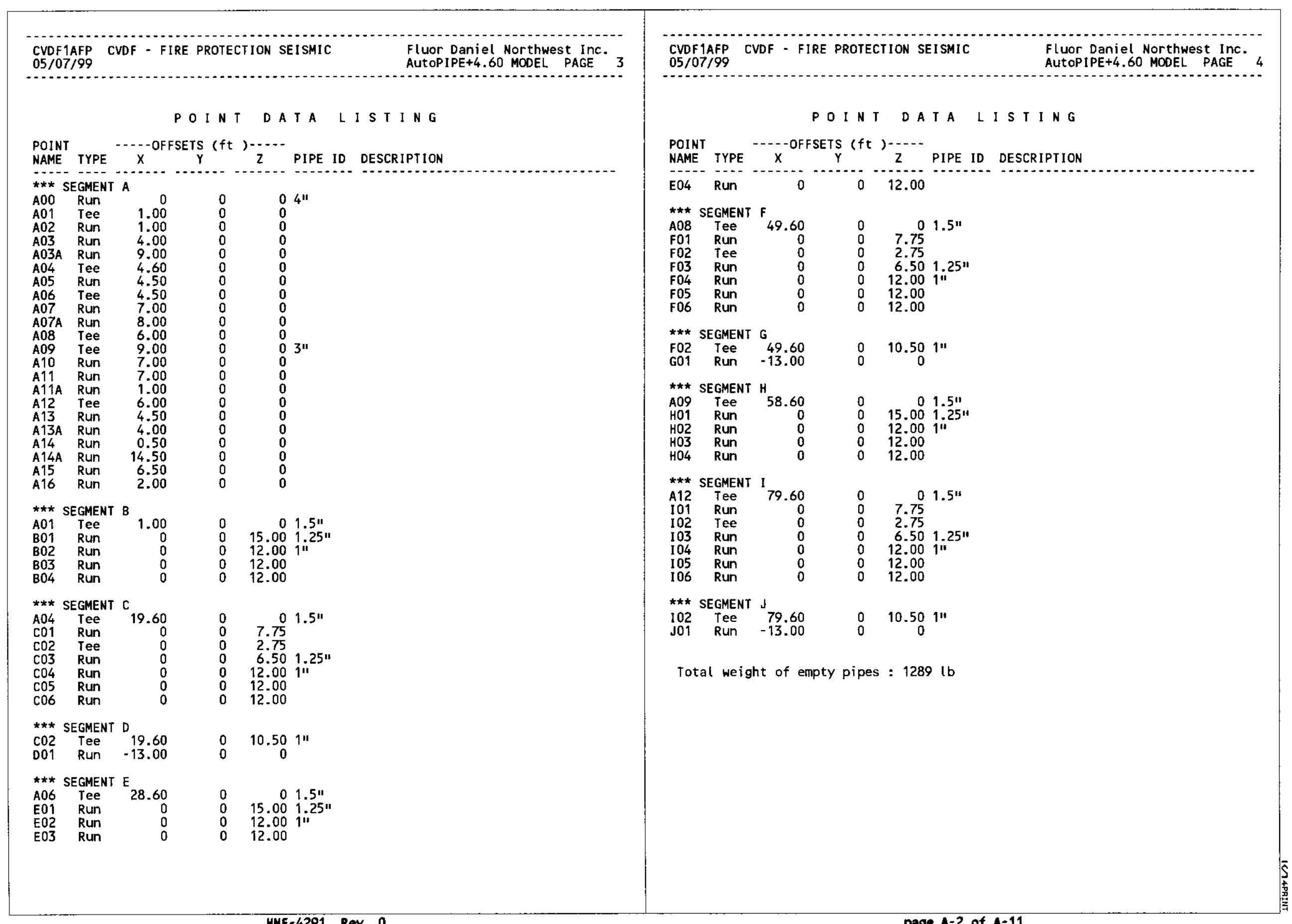




\begin{tabular}{|c|c|c|c|c|c|c|c|c|c|}
\hline $\begin{array}{l}\text { CVDF 1AFP } \\
05 / 07 / 99\end{array}$ & CVDF & FIRE PRC & ROTECTION SEIS & $\begin{array}{l}\text { Fluor Daniel Northwest Inc. } \\
\text { AutoP IPE+4.60 MODEL PAGE } 5\end{array}$ & $\begin{array}{l}\text { CVDF 1AFP } \\
05 / 07 / 99\end{array}$ & FP $\quad$ CVDF & - FIRE PR & ROTECTION SEISI & $\begin{array}{l}\text { Fluor Daniel Northwest Inc. } \\
\text { AutoPIPE+4.60 MODEL PAGE } 6\end{array}$ \\
\hline & & COMP & ONENT & DATA LISTING & & & COMP & PONENT & DATA LISTING \\
\hline $\begin{array}{l}\text { POINT } \\
\text { NAME }\end{array}$ & $\mathrm{X}^{--C O O R D}$ & INATE $(f t$ & $\begin{array}{ll}z^{--} & \text {DATA } \\
\text { TYPE }\end{array}$ & DESCR IPTION & $\begin{array}{l}\text { POINT - } \\
\text { NAME }\end{array}$ & $-x^{-\operatorname{COORD}}$ & NATE $(\mathrm{ft}$ & $\begin{array}{ll}2 \cdots & \text { DATA } \\
2 & \text { TYPE }\end{array}$ & DESCRIPTION \\
\hline $\begin{array}{l}* * * \\
A 00\end{array}$ & $\begin{array}{l}\text { MENT A } \\
0.00\end{array}$ & 0.00 & 0.00 ANCHOR & 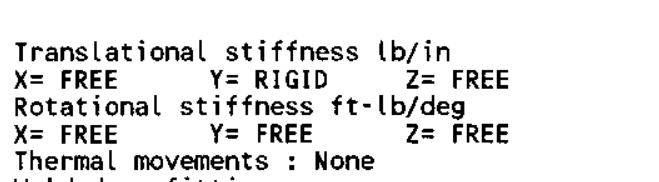 & A $14 \mathrm{~A}$ & 103.10 & 0.00 & 0.00 GUIDE & $\begin{array}{l}\text { ID : A14A 1, Connected to Ground } \\
\text { Stiffness }=\text { RIGID } \\
\text { Gap-down }=0.00, \text { Above }=0.00 \text { inch } \\
\text { Gap- }=6 \text { eft }=6.00, \text { Right }=6.00 \text { inch } \\
\text { Friction }=0.00 \\
\text { Gaps set weightless }\end{array}$ \\
\hline$A 01$ & 1.00 & 0.00 & 0.00 TEE & $\begin{array}{l}\text { Welded -on fitting } \\
\text { SIF - In }=2.81 \text {, out }=2.81\end{array}$ & $\begin{array}{l}\text { A15 } \\
\text { A16 }\end{array}$ & $\begin{array}{l}109.60 \\
111.60\end{array}$ & $\begin{array}{l}0.00 \\
0.00\end{array}$ & $\begin{array}{l}0.00 \\
0.00 \text { ANCHOR }\end{array}$ & Translational stiffness $\mathrm{lb} / \mathrm{i}$ \\
\hline $\mathrm{A} 02$ & 2.00 & 0.00 & 0.00 INCLIN & $\begin{array}{l}\text { ID : A02 } 1 \text { connected to Ground } \\
\text { Along global Z direction } \\
\text { Stiffness = RIGID } \\
\text { ID : A02 2, Connected to Ground }\end{array}$ & & & & & 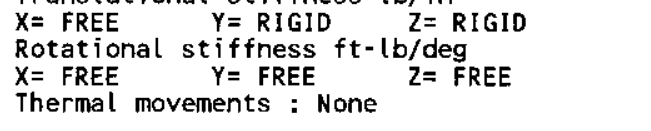 \\
\hline $\begin{array}{l}\text { A03 } \\
\text { A03A }\end{array}$ & $\begin{array}{r}6.00 \\
15.00\end{array}$ & $\begin{array}{l}0.00 \\
0.00\end{array}$ & $\begin{array}{l}0.00 \\
0.00\end{array}$ & ID : A03A 1 , Connected to Ground & $\star \star \star \star$ SEGM & IMENT B & & & \\
\hline A04 & 19.60 & 0.00 & $0.00 \mathrm{TEE}$ & $\begin{array}{l}\text { Welded-on fitting } \\
\text { SIF }- \text { In }=2.81 \text {, out }=2.81\end{array}$ & A01 & 1.00 & 0.00 & 0.00 TEE & $\begin{array}{l}\text { Welded-on fitting } \\
\text { SIF }- \text { In }=2.81 \text {, out }=2.81\end{array}$ \\
\hline A05 & 24.10 & 0.00 & 0.00 INCLIN & $\begin{array}{l}\text { ID : A05 } 1 \text { Connected to Ground } \\
\text { Along global X direction } \\
\text { Stiffness = RIGID }\end{array}$ & B01 & 1.00 & 0.00 & 15.00 GUIDE & $\begin{array}{l}\text { ID : BOI 1, connected to Ground } \\
\text { Stiffness }=\text { RIGID } \\
\text { Gap-down }=0.00 \text {, Above }=0.00 \text { inch }\end{array}$ \\
\hline A06 & 28.60 & 0.00 & $\begin{array}{c}0.00 \text { TEE } \\
Y \text {-STOP }\end{array}$ & $\begin{array}{l}\text { Welded on fitting } \\
\text { SIF - In }=2.81 \text {, out }=2.81 \\
\text { ID : A06 } 1, \text { Connected to Ground }\end{array}$ & & & & & $\begin{array}{l}\text { Gap-left }=6.00, \text { Right }=6.00 \text { inch } \\
\text { Friction }=0.00 \\
\text { Gaps set Weightless }\end{array}$ \\
\hline A07 & 35.60 & 0.00 & 0.00 INCLIN & $\begin{array}{l}\text { ID A07 í connected to Ground } \\
\text { Along global } z \text { direction } \\
\text { Stiffness }=\text { RIGID } \\
\text { Gap-Minus }=0.50, \text { Plus }=0.50 \text { inch } \\
\text { Friction }=0.00 \\
\text { Gaps set Weightless }\end{array}$ & B02 & 1.00 & 0.00 & 27.00 GUIDE & $\begin{array}{l}\text { ID B B02 } 1 \text { ' Connected to Ground } \\
\text { Stiffness = RIGID } \\
\text { Gap-down }=0.00, \text { Above }=0.00 \text { inch } \\
\text { Gap-left }=6.00, \text { Right }=6.00 \text { inch } \\
\text { Friction }=0.00 \\
\text { Gaps set Weightless }\end{array}$ \\
\hline $\begin{array}{l}A 07 A \\
A 08\end{array}$ & $\begin{array}{l}43.60 \\
49.60\end{array}$ & $\begin{array}{l}0.00 \\
0.00\end{array}$ & $\begin{array}{l}0.00 Y \text { Y-STOP } \\
0.00 \mathrm{TEE}\end{array}$ & $\begin{array}{l}\text { ID : A07A } 1 \text {, Connected to Ground } \\
\text { Welded-on fitting } \\
\text { SIF }- \text { in }=2.81 \text {, out }=2.81\end{array}$ & B03 & 1.00 & 0.00 & 39.00 GUIDE & $\begin{array}{l}\text { ID = B03 1 Connected to Ground } \\
\text { Stiffness }=\text { RIGID } \\
\text { Gap-down }=0.00, \text { Above }=0.00 \text { inch }\end{array}$ \\
\hline A09 & 58.60 & 0.00 & $\begin{array}{r}0.00 \text { TEE } \\
Y \text {-STOP }\end{array}$ & $\begin{array}{l}\text { Weided-on fitting } \\
\text { SIF } \text { In }=2.81 \text {, out }=2.81 \\
\text { ID : A09 } 1 \text {, Connected to Ground }\end{array}$ & & & & & $\begin{array}{l}\text { Gap-left }=6.00, \text { Right }=6.00 \text { inch } \\
\text { Friction }=0.00 \\
\text { Gaps set Weightless }\end{array}$ \\
\hline $\begin{array}{l}\text { A10 } \\
\text { A11 }\end{array}$ & $\begin{array}{l}65.60 \\
72.60\end{array}$ & $\begin{array}{l}0.00 \\
0.00\end{array}$ & 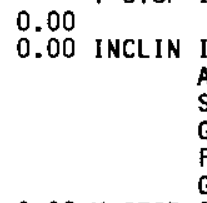 & $\begin{array}{l}\text { ID : A11 } 1 \text {, Connected to Ground } \\
\text { Along global } 2 \text { direction } \\
\text { Stiffness }=\text { RIGID } \\
\text { Gap-Minus }=0.50, \text { Plus }=0.50 \text { inch } \\
\text { Friction }=0.00 \\
\text { Gaps set Weightless }\end{array}$ & B04 & 1.00 & 0.00 & 51.00 GUIDE & $\begin{array}{l}\text { ID }=\text { B04 1, Connected to Ground } \\
\text { Stiffness }=\text { RIGID } \\
\text { Gap-down }=0.00, \text { Above }=0.00 \text { inch } \\
\text { Gap-left }=6.00, \text { Right }=6.00 \text { inch } \\
\text { Friction }=0.00 \\
\text { Gaps set Weightless }\end{array}$ \\
\hline $\begin{array}{l}\text { A11A } \\
\text { A12 }\end{array}$ & $\begin{array}{l}73.60 \\
79.60\end{array}$ & $\begin{array}{l}0.00 \\
0.00\end{array}$ & $\begin{array}{l}0.00 \mathrm{Y-STOP} \\
0.00 \mathrm{TEE}\end{array}$ & $\begin{array}{l}\text { ID : A11A } 1 \text { Connected to Ground } \\
\text { Welded-on fitting } \\
\text { SIF }- \text { In }=2.37 \text { out }=2.37\end{array}$ & $\begin{array}{l}* * * \\
\text { A04 }\end{array}$ & $\begin{array}{l}\text { MENT C } \\
19.60\end{array}$ & 0.00 & $0.00 \mathrm{TEE}$ & $\begin{array}{l}\text { Welded-on fitting } \\
\text { SIF }-I n=2.81 \text { out }=2.81\end{array}$ \\
\hline A13 & 84.10 & 0.00 & 0.00 INCLIN & $\begin{array}{l}\text { ID : A13 1 connected to Ground } \\
\text { Along global } x \text { direction } \\
\text { stiffess = RIGID }\end{array}$ & C01 & 19.60 & 0.00 & 7.75 GUIDE & $\begin{array}{l}\text { ID } \text { co1 } 1 \text { connected to Ground } \\
\text { Stiffness = RIGID }\end{array}$ \\
\hline $\begin{array}{l}\text { A13A } \\
\text { A14 }\end{array}$ & $\begin{array}{l}88.10 \\
88.60\end{array}$ & $\begin{array}{l}0.00 \\
0.00\end{array}$ & $\begin{array}{l}0.00 Y \text { Y-STOP I } \\
0.00\end{array}$ & ID : A13A 1, Connected to Ground & & & & & $\begin{array}{l}\text { Gap-left }=6.00, \text { Right }=6.00 \text { inch } \\
\text { Friction }=0.00\end{array}$ \\
\hline
\end{tabular}




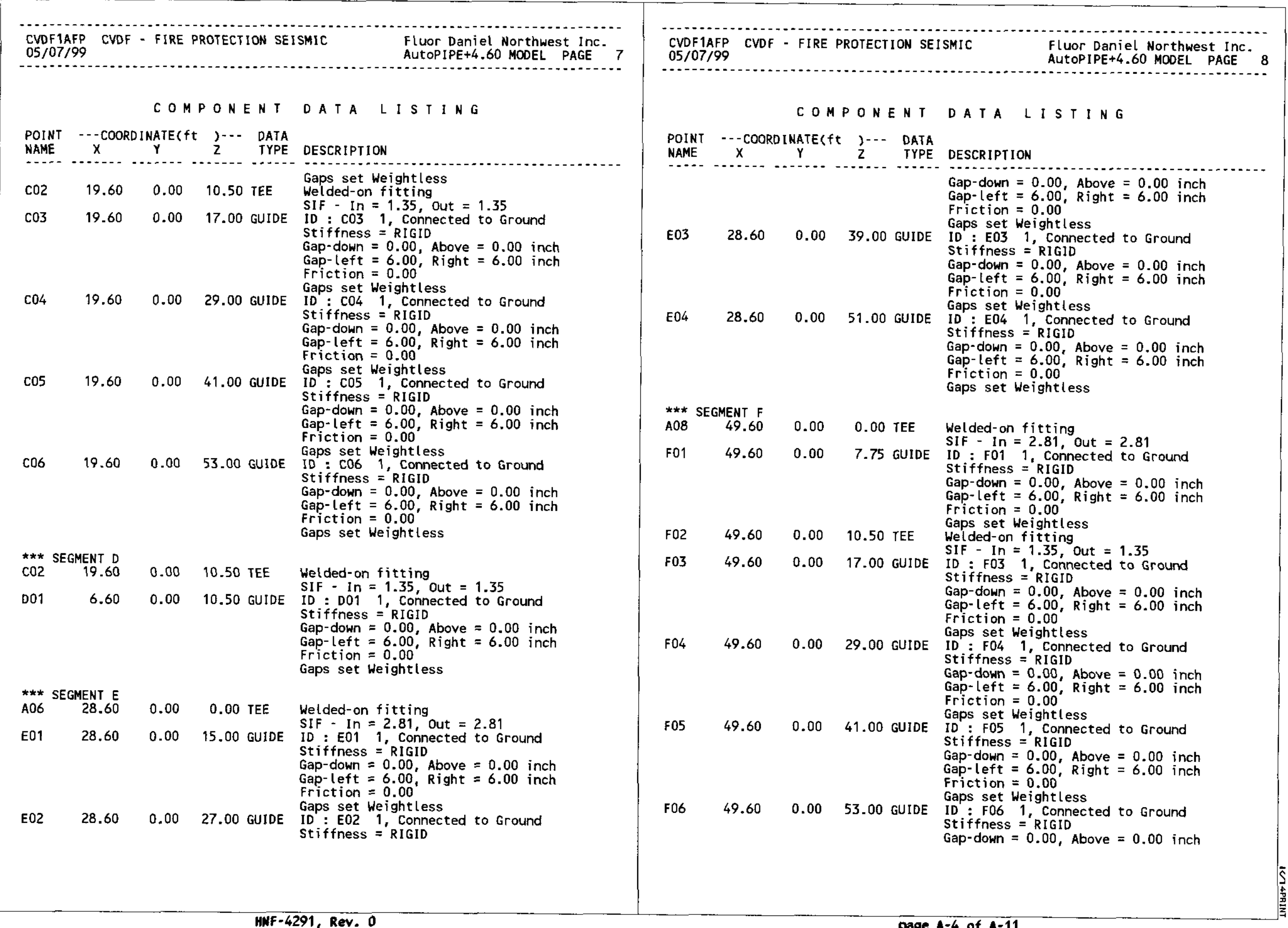




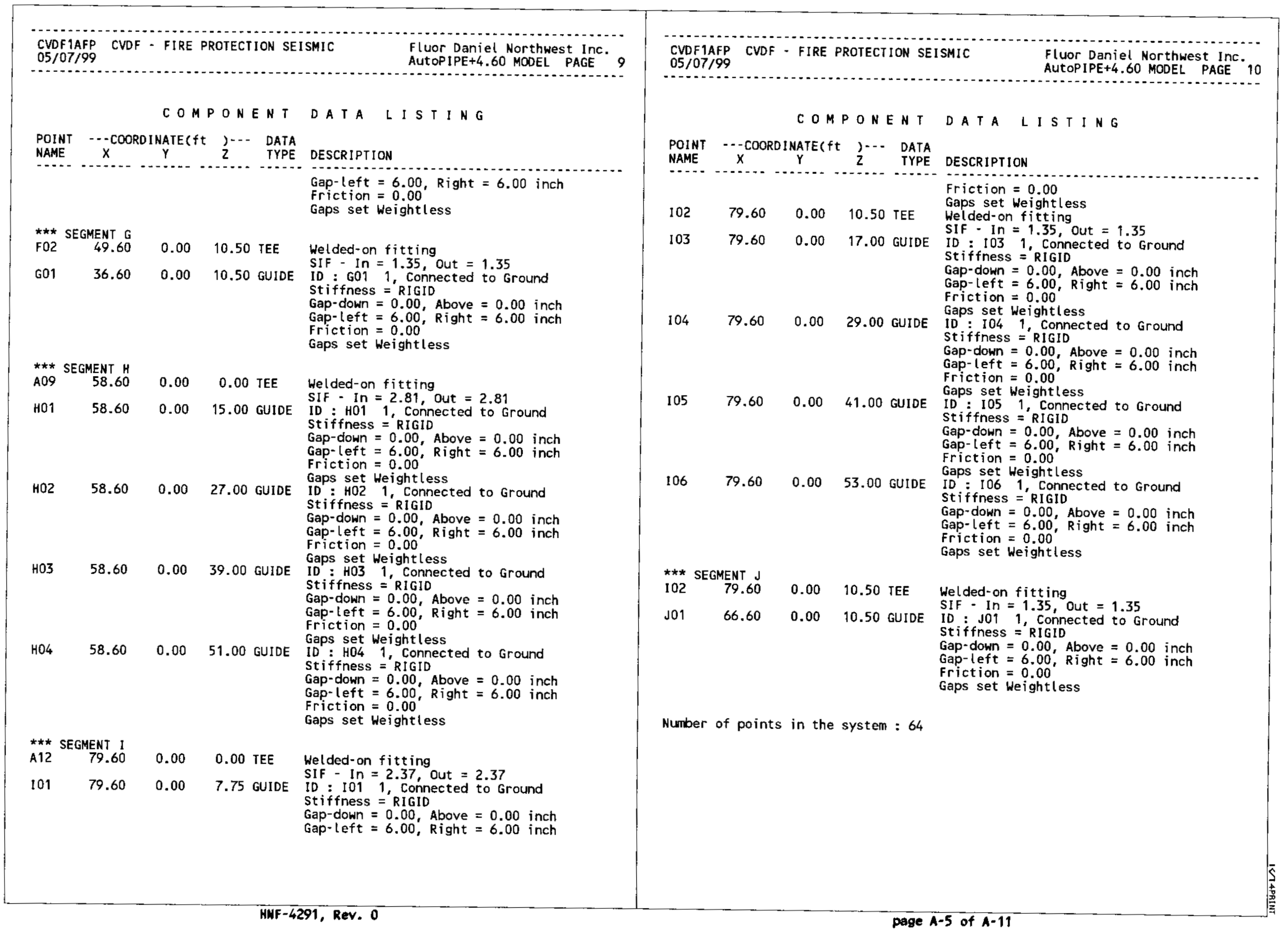




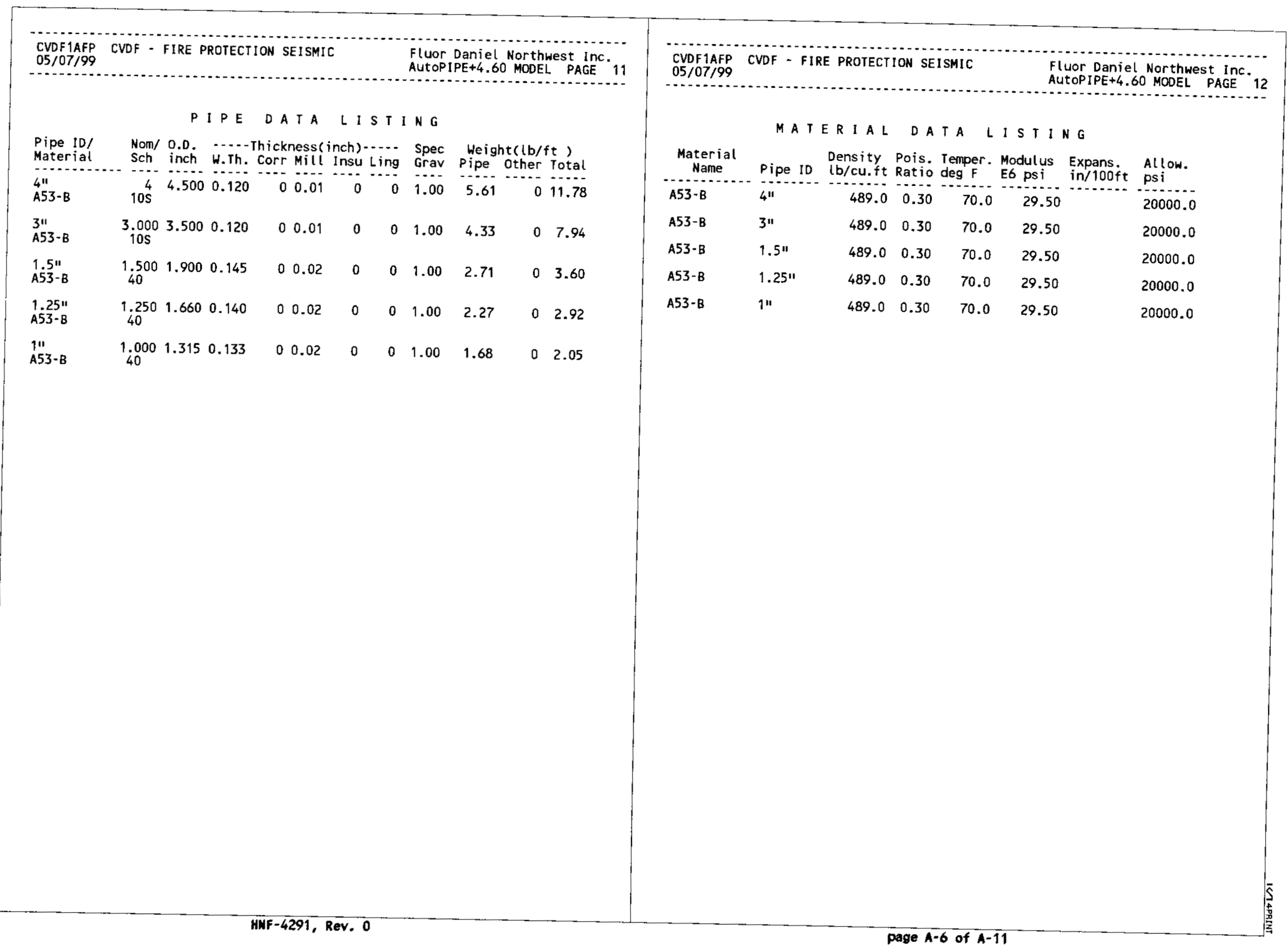




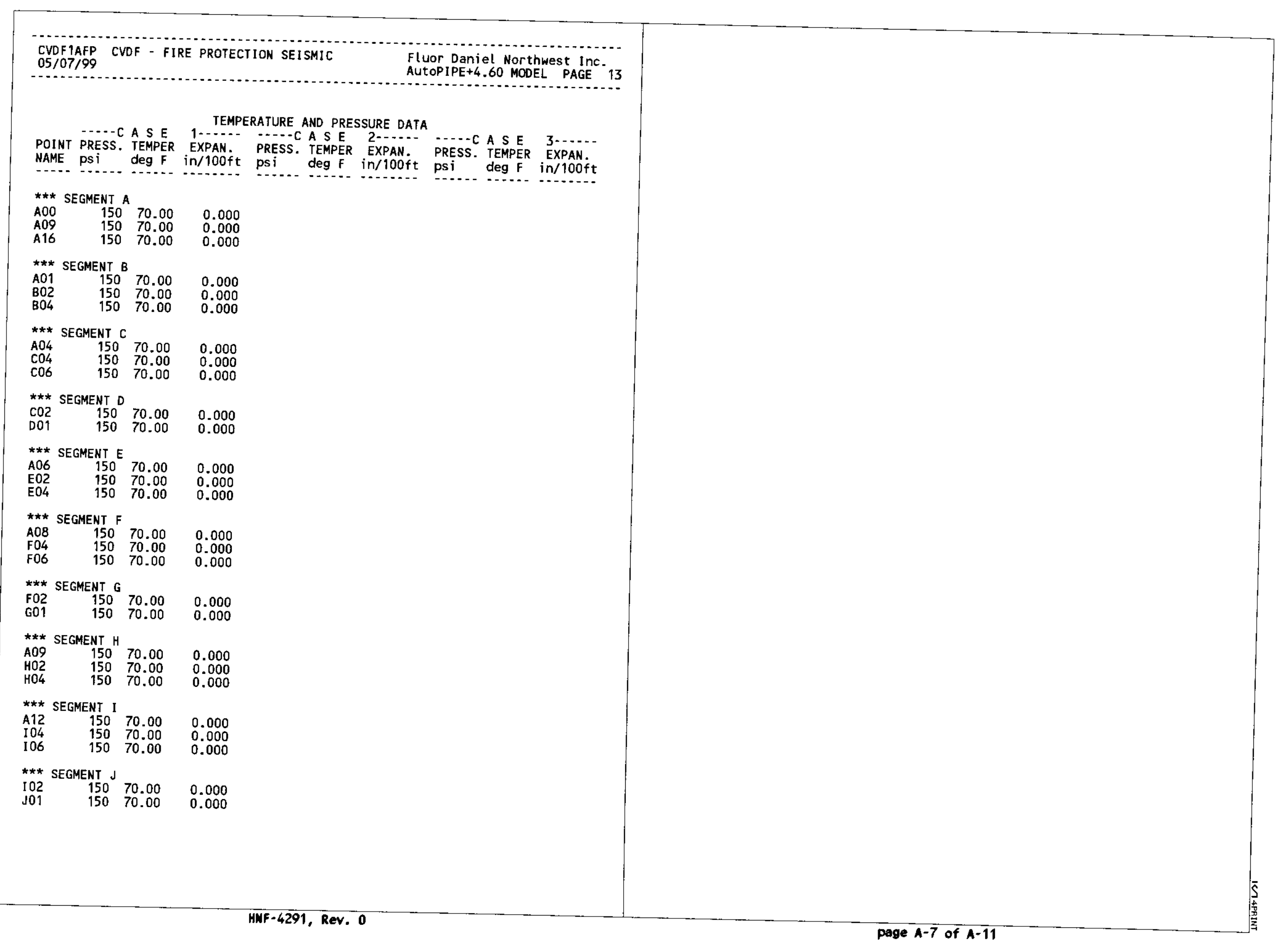




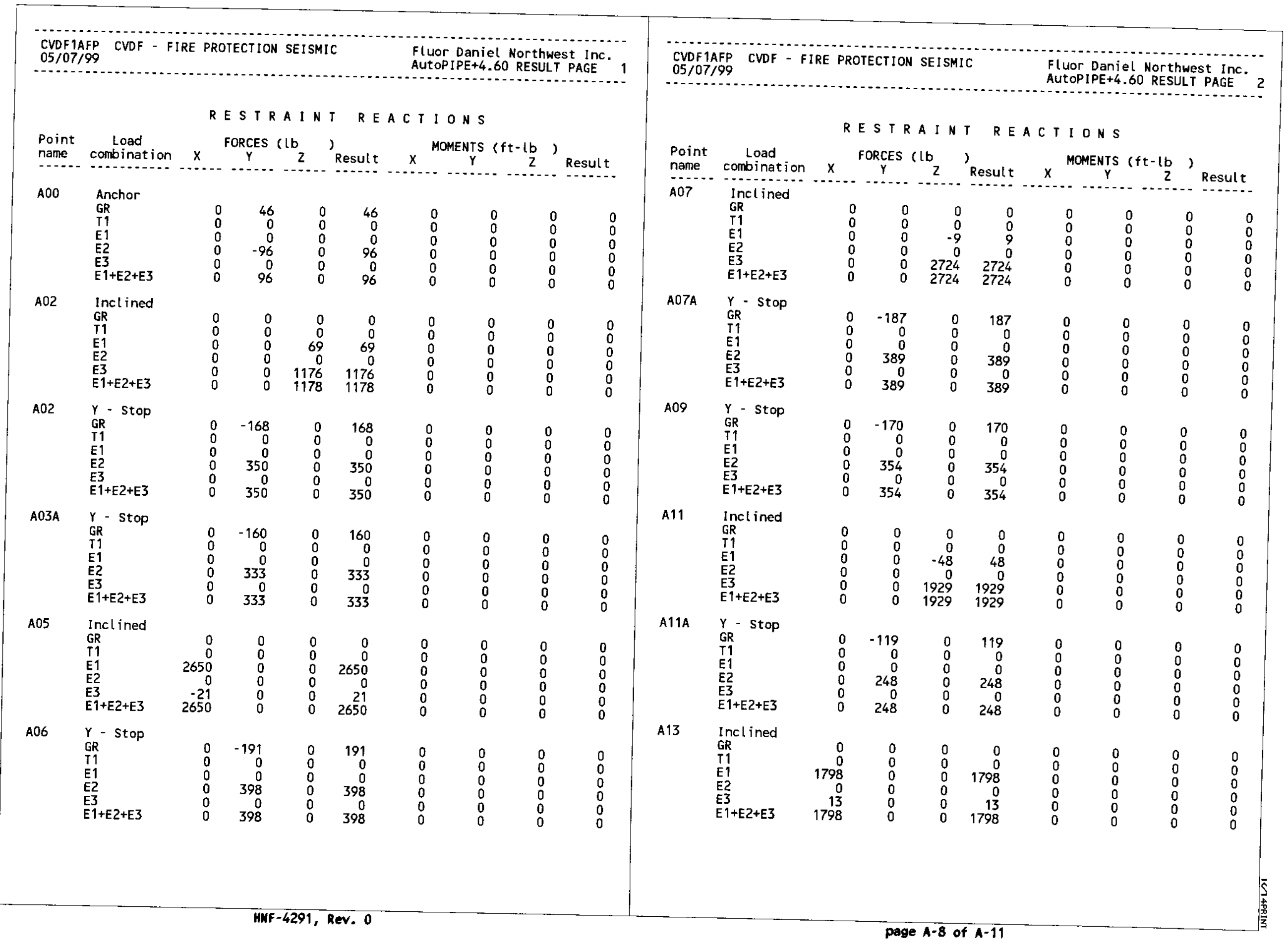




\begin{tabular}{|c|c|c|c|c|c|c|c|c|c|c|c|c|c|c|c|c|c|c|c|}
\hline $\begin{array}{l}\text { CVDF } 1 \text { AFP } \\
0507 / 99\end{array}$ & \multirow{3}{*}{$\begin{array}{l}99 \text { CVDF - FIRE } \\
\text { Load } \\
\text { combination }\end{array}$} & \multicolumn{3}{|c|}{ E PROTECTION SEISMIC } & \multicolumn{5}{|c|}{$\begin{array}{l}\text { Fluor Dani el Nor thwest Inc. } \\
\text { AutoPIPE+4.60 RESUL T PAGE }\end{array}$} & \multicolumn{6}{|c|}{$\begin{array}{l}\text { CVDFIAFP } \\
05 / 07 / 99\end{array}$} & \multicolumn{4}{|c|}{$\begin{array}{l}\text { Fluor Daniel Northwest Inc. } \\
\text { AutoPIPE+4.60 RESULT PAGE }\end{array}$} \\
\hline \multicolumn{9}{|c|}{ RESTRAINT REACTIONS } & & \multicolumn{10}{|c|}{ RESTRAINT REACTIONS } \\
\hline $\begin{array}{l}\text { Point } \\
\text { name }\end{array}$ & & $x^{\mathrm{F}}$ & $\begin{array}{l}\text { ORCES }(1) \\
Y \\
-\end{array}$ & $b_{2}$, & esult & $x^{\text {MON }}$ & Is $(f t-l b$ & ${ }_{R \in}$ & & $\begin{array}{l}\text { Point } \\
\text { name } \\
\text { - }\end{array}$ & $\begin{array}{l}\text { load } \\
\text { combination }\end{array}$ & & $\begin{array}{l}\text { RCES } \\
Y\end{array}$ & 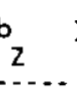 & Result & $x^{\text {MOME }}$ & $(s(f t-l b)$ & Resul & \\
\hline A13A & $\begin{array}{l}Y-\text { Stop } \\
G R \\
T 1 \\
E 1 \\
E 2 \\
E 3 \\
E 1+E 2+E 3\end{array}$ & $\begin{array}{l}0 \\
0 \\
0 \\
0 \\
0 \\
0\end{array}$ & $\begin{array}{r}-121 \\
0 \\
0 \\
252 \\
0 \\
252\end{array}$ & $\begin{array}{l}0 \\
0 \\
0 \\
0 \\
0 \\
0\end{array}$ & $\begin{array}{r}121 \\
0 \\
0 \\
252 \\
0 \\
252\end{array}$ & $\begin{array}{l}0 \\
0 \\
0 \\
0 \\
0 \\
0\end{array}$ & $\begin{array}{l}0 \\
0 \\
0 \\
0 \\
0 \\
0\end{array}$ & $\begin{array}{l}0 \\
0 \\
0 \\
0 \\
0 \\
0\end{array}$ & $\begin{array}{l}0 \\
0 \\
0 \\
0 \\
0 \\
0\end{array}$ & B04 & $\begin{array}{l}\text { Guide } \\
\text { GR } \\
\text { T1 } \\
\text { E1 } \\
\text { E2 } \\
\text { E3 } \\
\text { E1+E2+E3 }\end{array}$ & $\begin{array}{r}0 \\
0 \\
31 \\
0 \\
0 \\
31\end{array}$ & $\begin{array}{r}-10 \\
0 \\
0 \\
20 \\
0 \\
20\end{array}$ & $\begin{array}{l}0 \\
0 \\
0 \\
0 \\
0 \\
0\end{array}$ & $\begin{array}{r}10 \\
0 \\
31 \\
20 \\
0 \\
37\end{array}$ & $\begin{array}{l}0 \\
0 \\
0 \\
0 \\
0 \\
0\end{array}$ & $\begin{array}{l}0 \\
0 \\
0 \\
0 \\
0 \\
0\end{array}$ & $\begin{array}{l}0 \\
0 \\
0 \\
0 \\
0 \\
0\end{array}$ & $\begin{array}{l}0 \\
0 \\
0 \\
0 \\
0 \\
0\end{array}$ \\
\hline A14A & $\begin{array}{l}\text { Guide } \\
\text { GR } \\
\text { T1 } \\
\text { E1 } \\
\text { E2 } \\
\text { E3 } \\
\text { E1+E2+E3 }\end{array}$ & $\begin{array}{l}0 \\
0 \\
0 \\
0 \\
0 \\
0 \\
0\end{array}$ & $\begin{array}{r}-105 \\
0 \\
0 \\
218 \\
0 \\
218\end{array}$ & $\begin{array}{r}0 \\
0 \\
0 \\
0 \\
225 \\
225\end{array}$ & $\begin{array}{r}105 \\
0 \\
0 \\
218 \\
225 \\
313\end{array}$ & $\begin{array}{l}0 \\
0 \\
0 \\
0 \\
0 \\
0\end{array}$ & $\begin{array}{l}0 \\
0 \\
0 \\
0 \\
0 \\
0\end{array}$ & $\begin{array}{l}0 \\
0 \\
0 \\
0 \\
0 \\
0\end{array}$ & $\begin{array}{l}0 \\
0 \\
0 \\
0 \\
0 \\
0\end{array}$ & $\mathrm{C} 01$ & $\begin{array}{l}\text { Guide } \\
\text { GR } \\
\text { T1 } \\
\text { E1 } \\
\text { E2 } \\
\text { E3 } \\
\text { E1+E2+E3 }\end{array}$ & $\begin{array}{l}0 \\
0 \\
0 \\
0 \\
0 \\
0\end{array}$ & $\begin{array}{r}-56 \\
0 \\
0 \\
116 \\
0 \\
116\end{array}$ & $\begin{array}{l}0 \\
0 \\
0 \\
0 \\
0 \\
0\end{array}$ & $\begin{array}{r}56 \\
0 \\
0 \\
116 \\
0 \\
116\end{array}$ & $\begin{array}{l}0 \\
0 \\
0 \\
0 \\
0 \\
0\end{array}$ & $\begin{array}{l}0 \\
0 \\
0 \\
0 \\
0 \\
0\end{array}$ & $\begin{array}{l}0 \\
0 \\
0 \\
0 \\
0 \\
0\end{array}$ & $\begin{array}{l}0 \\
0 \\
0 \\
0 \\
0 \\
0\end{array}$ \\
\hline A16 & $\begin{array}{l}\text { Anchor } \\
\text { GR } \\
\text { I1 } \\
E 1 \\
E 2 \\
E 3 \\
E 1+E 2+E 3\end{array}$ & $\begin{array}{l}0 \\
0 \\
0 \\
0 \\
0 \\
0\end{array}$ & $\begin{array}{r}-20 \\
0 \\
0 \\
41 \\
0 \\
41\end{array}$ & $\begin{array}{r}0 \\
0 \\
-12 \\
0 \\
229 \\
229\end{array}$ & $\begin{array}{r}20 \\
0 \\
12 \\
41 \\
229 \\
233\end{array}$ & $\begin{array}{l}0 \\
0 \\
0 \\
0 \\
0 \\
0\end{array}$ & $\begin{array}{l}0 \\
0 \\
0 \\
0 \\
0 \\
0\end{array}$ & $\begin{array}{l}0 \\
0 \\
0 \\
0 \\
0 \\
0 \\
0\end{array}$ & $\begin{array}{l}0 \\
0 \\
0 \\
0 \\
0 \\
0\end{array}$ & $\cos$ & $\begin{array}{l}\text { Guide } \\
\text { GR } \\
T 1 \\
\text { E1 } \\
\text { E2 } \\
\text { E3 } \\
\text { E1+E2+E3 }\end{array}$ & $\begin{array}{r}0 \\
0 \\
139 \\
0 \\
0 \\
139\end{array}$ & $\begin{array}{r}-38 \\
0 \\
0 \\
80 \\
0 \\
80\end{array}$ & $\begin{array}{l}0 \\
0 \\
0 \\
0 \\
0 \\
0\end{array}$ & $\begin{array}{r}38 \\
0 \\
139 \\
80 \\
0 \\
160\end{array}$ & $\begin{array}{l}0 \\
0 \\
0 \\
0 \\
0 \\
0\end{array}$ & $\begin{array}{l}0 \\
0 \\
0 \\
0 \\
0 \\
0\end{array}$ & $\begin{array}{l}0 \\
0 \\
0 \\
0 \\
0 \\
0\end{array}$ & $\begin{array}{l}0 \\
0 \\
0 \\
0 \\
0 \\
0\end{array}$ \\
\hline B01 & $\begin{array}{l}\text { Guide } \\
\text { GR } \\
\text { T1 } \\
\text { E1 } \\
\text { E2 } \\
\text { E3 } \\
\text { E1+E2+E3 }\end{array}$ & $\begin{array}{r}0 \\
0 \\
57 \\
0 \\
0 \\
57\end{array}$ & $\begin{array}{r}-50 \\
0 \\
0 \\
103 \\
0 \\
103\end{array}$ & $\begin{array}{l}0 \\
0 \\
0 \\
0 \\
0 \\
0\end{array}$ & $\begin{array}{r}50 \\
0 \\
57 \\
103 \\
0 \\
118\end{array}$ & $\begin{array}{l}0 \\
0 \\
0 \\
0 \\
0 \\
0\end{array}$ & $\begin{array}{l}0 \\
0 \\
0 \\
0 \\
0 \\
0\end{array}$ & $\begin{array}{l}0 \\
0 \\
0 \\
0 \\
0 \\
0\end{array}$ & $\begin{array}{l}0 \\
0 \\
0 \\
0 \\
0 \\
0\end{array}$ & $\mathrm{CO4}$ & $\begin{array}{l}\text { Guide } \\
\text { GR } \\
T 1 \\
\text { E1 } \\
E 2 \\
\text { E3 } \\
\text { E1+E2+E3 }\end{array}$ & $\begin{array}{r}0 \\
0 \\
102 \\
0 \\
0 \\
102\end{array}$ & $\begin{array}{r}-28 \\
0 \\
0 \\
59 \\
0 \\
59\end{array}$ & $\begin{array}{l}0 \\
0 \\
0 \\
0 \\
0 \\
0\end{array}$ & $\begin{array}{r}28 \\
0 \\
102 \\
59 \\
0 \\
117\end{array}$ & $\begin{array}{l}0 \\
0 \\
0 \\
0 \\
0 \\
0\end{array}$ & $\begin{array}{l}0 \\
0 \\
0 \\
0 \\
0 \\
0\end{array}$ & $\begin{array}{l}0 \\
0 \\
0 \\
0 \\
0 \\
0\end{array}$ & $\begin{array}{l}0 \\
0 \\
0 \\
0 \\
0 \\
0\end{array}$ \\
\hline $\mathrm{B} 02$ & $\begin{array}{l}\text { Guide } \\
\text { GR } \\
\text { T1 } \\
\text { E1 } \\
\text { E2 } \\
\text { E3 } \\
\text { E1+E2+E3 }\end{array}$ & $\begin{array}{r}0 \\
0 \\
119 \\
0 \\
-9 \\
120\end{array}$ & $\begin{array}{r}-26 \\
0 \\
0 \\
53 \\
0 \\
53\end{array}$ & $\begin{array}{l}0 \\
0 \\
0 \\
0 \\
0 \\
0\end{array}$ & $\begin{array}{r}26 \\
0 \\
119 \\
53 \\
9 \\
131\end{array}$ & $\begin{array}{l}0 \\
0 \\
0 \\
0 \\
0 \\
0\end{array}$ & $\begin{array}{l}0 \\
0 \\
0 \\
0 \\
0 \\
0\end{array}$ & $\begin{array}{l}0 \\
0 \\
0 \\
0 \\
0 \\
0\end{array}$ & $\begin{array}{l}0 \\
0 \\
0 \\
0 \\
0 \\
0\end{array}$ & $\mathrm{CO5}$ & $\begin{array}{l}\text { Guide } \\
\text { GR } \\
\text { I1 } \\
\text { E1 } \\
\text { E2 } \\
\text { E3 } \\
\text { E1+E2+E3 }\end{array}$ & $\begin{array}{r}0 \\
0 \\
84 \\
0 \\
-9 \\
84\end{array}$ & $\begin{array}{r}-28 \\
0 \\
0 \\
57 \\
0 \\
57\end{array}$ & $\begin{array}{l}0 \\
0 \\
0 \\
0 \\
0 \\
0\end{array}$ & $\begin{array}{r}28 \\
0 \\
84 \\
57 \\
9 \\
102\end{array}$ & $\begin{array}{l}0 \\
0 \\
0 \\
0 \\
0 \\
0\end{array}$ & $\begin{array}{l}0 \\
0 \\
0 \\
0 \\
0 \\
0\end{array}$ & $\begin{array}{l}0 \\
0 \\
0 \\
0 \\
0 \\
0\end{array}$ & $\begin{array}{l}0 \\
0 \\
0 \\
0 \\
0 \\
0\end{array}$ \\
\hline $\mathrm{B} 03$ & $\begin{array}{l}\text { Guide } \\
\text { GR } \\
\text { T1 } \\
\text { E1 } \\
\text { E2 } \\
\text { E3 } \\
\text { E1+E2+E3 }\end{array}$ & $\begin{array}{r}0 \\
0 \\
80 \\
0 \\
0 \\
80\end{array}$ & $\begin{array}{r}-28 \\
0 \\
0 \\
58 \\
0 \\
58\end{array}$ & $\begin{array}{l}0 \\
0 \\
0 \\
0 \\
0 \\
0\end{array}$ & $\begin{array}{r}28 \\
0 \\
80 \\
58 \\
0 \\
99\end{array}$ & $\begin{array}{l}0 \\
0 \\
0 \\
0 \\
0 \\
0\end{array}$ & $\begin{array}{l}0 \\
0 \\
0 \\
0 \\
0 \\
0\end{array}$ & $\begin{array}{l}0 \\
0 \\
0 \\
0 \\
0 \\
0\end{array}$ & $\begin{array}{l}0 \\
0 \\
0 \\
0 \\
0 \\
0\end{array}$ & C06 & $\begin{array}{l}\text { Guide } \\
\text { GR } \\
T 1 \\
E 1 \\
E 2 \\
E 3 \\
E 1+E 2+E 3\end{array}$ & $\begin{array}{r}0 \\
0 \\
31 \\
0 \\
0 \\
31\end{array}$ & $\begin{array}{r}-10 \\
0 \\
0 \\
20 \\
0 \\
20\end{array}$ & $\begin{array}{l}0 \\
0 \\
0 \\
0 \\
0 \\
0\end{array}$ & $\begin{array}{r}10 \\
0 \\
31 \\
20 \\
0 \\
37\end{array}$ & $\begin{array}{l}0 \\
0 \\
0 \\
0 \\
0 \\
0\end{array}$ & $\begin{array}{l}0 \\
0 \\
0 \\
0 \\
0 \\
0\end{array}$ & $\begin{array}{l}0 \\
0 \\
0 \\
0 \\
0 \\
0\end{array}$ & $\begin{array}{l}0 \\
0 \\
0 \\
0 \\
0 \\
0\end{array}$ \\
\hline
\end{tabular}




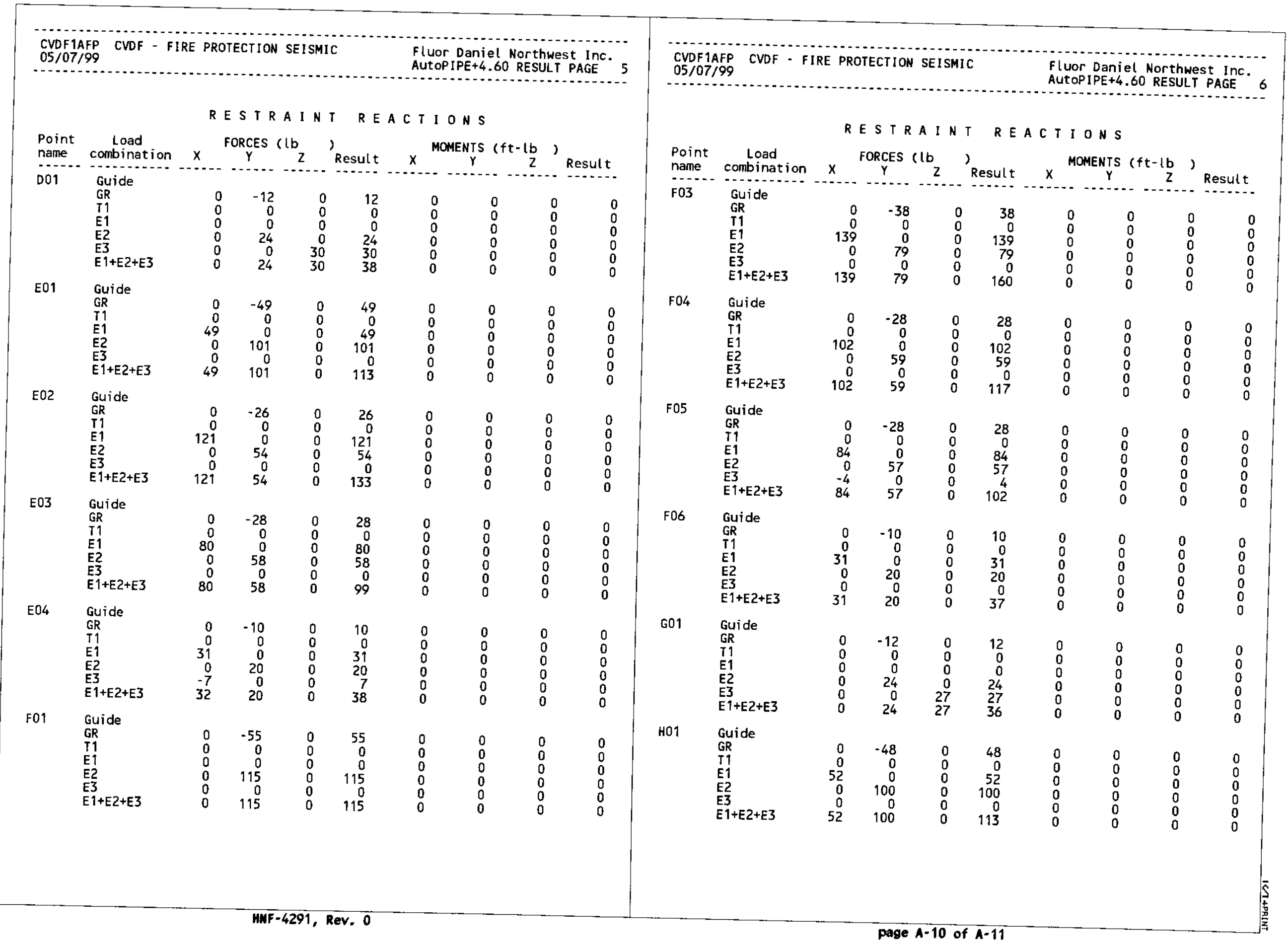




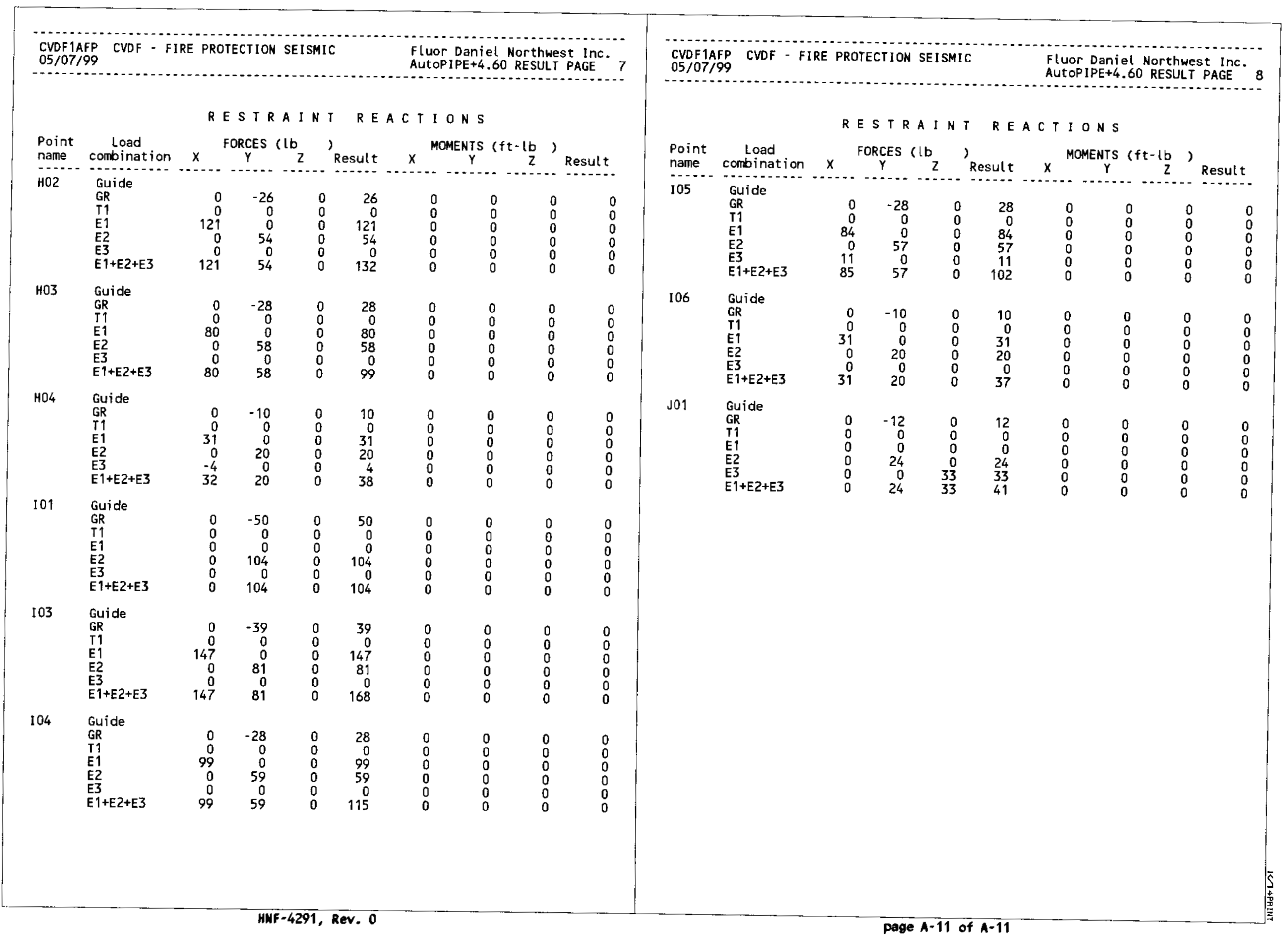




\section{CORRESPONDENCE DISTRIBUTION COVERSHEET}

Author

EC Ocoma

$376-0332$
Addressee

T Choho
Correspondence No.

EDT 615963

Subject: COLD VACUUM DRYING FACILITY SEISMIC 3/1 EVALUATION

\section{DISTRIBUTION}

\begin{tabular}{|c|c|c|c|c|}
\hline \multirow[t]{15}{*}{ Approval } & Date & Name & Location & w/att \\
\hline & & Correspondence Control & A3-01 & \\
\hline & & KA Boes & $\mathrm{R} 3-86$ & $X(3)$ \\
\hline & & JR Brehm & $\mathrm{R} 3-26$ & $X$ \\
\hline & & SA Brisbin & R3-86 & $X$ \\
\hline & & T Choho & $\mathrm{R} 3-86$ & $\mathrm{X}$ \\
\hline & & CS Haller & R3-11 & $\mathrm{X}$ \\
\hline & & $\mathrm{JJ}$ Irwin & $\mathrm{R} 3-86$ & $X$ \\
\hline & & SL Mischke & $\mathrm{R} 3-86$ & $\mathrm{X}$ \\
\hline & & CR Miska & $\mathrm{R} 3-86$ & $X$ \\
\hline & & EC Ocoma & B4-40 & $\mathbf{X}$ \\
\hline & & CC Pitkoff & R3-86 & $\mathrm{X}$ \\
\hline & & R Whitehurst & R3-86 & $X$ \\
\hline & & R Routh & Mactec & $\mathrm{X}$ \\
\hline & & & Meier & \\
\hline
\end{tabular}

